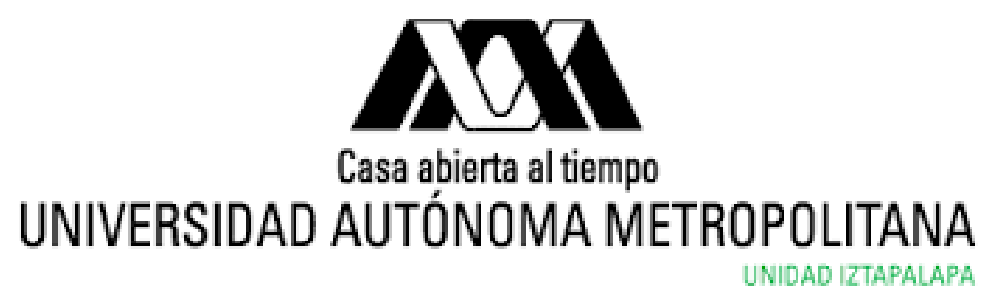

División de Ciencias Sociales y Humanidades

Departamento de filosofía

Maestría en Humanidades, Línea lingüística

\title{
EL USO DE DETERMINANTES EN CONSTRUCCIONES CON ORACIONES SUBORDINADAS RELATIVAS
}

Idónea Comunicación de Resultados

\author{
que para obtener el título de \\ Maestro en Humanidades \\ (Lingüística) \\ Presenta
}

Jorge Luis Morales Pérez

Director de tesis: Dr. José Lema Labadie

Lectoras:

Dra. Antoinette Hawayek González

Dra. Laura Jiménez Norberto

Julio 2019 
Introducción

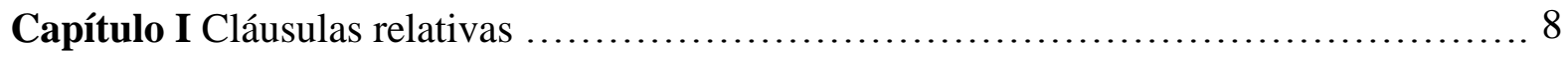

1.1 CRs. restrictivas con antecedente vs CRs. explicativas ......................... 10

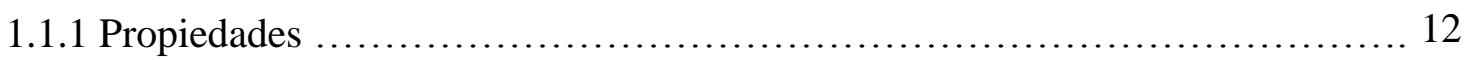

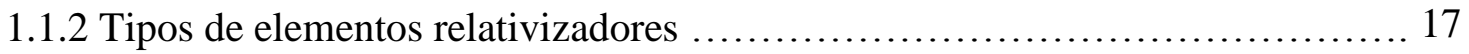

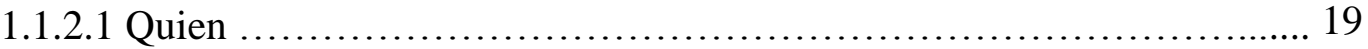

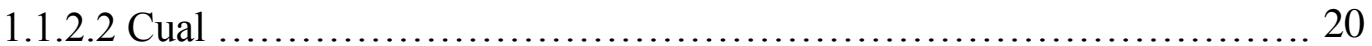

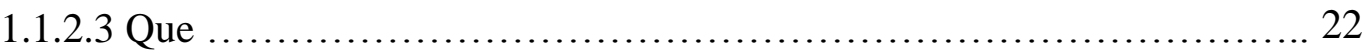

1.1.3 Análisis ................................................................... 31

1.1.3.1 Que pronombre y movimiento a SC $\ldots \ldots \ldots \ldots \ldots \ldots \ldots \ldots \ldots \ldots \ldots . \ldots \ldots 1$

1.1.3.2 Que complementante y movimiento a Espec C (2 posiciones) ............ 37

1.1.3.3 Que complementante $\mathrm{C}^{\circ}$ análisis de Brame (2 posiciones) ........... 38

Capítulo II Headless relatives en español ......................................... 44

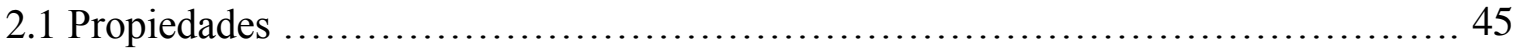

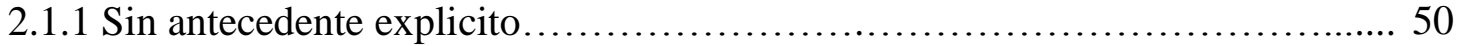

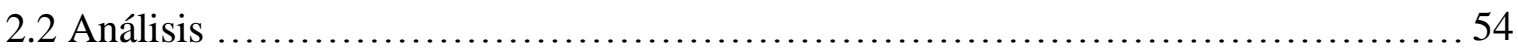

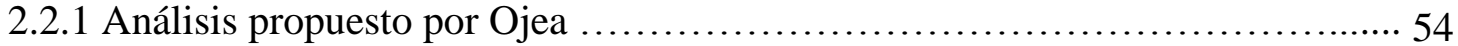

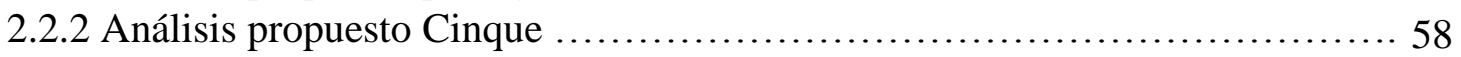

2.2.3 Análisis Headles relatives .............................................. 61

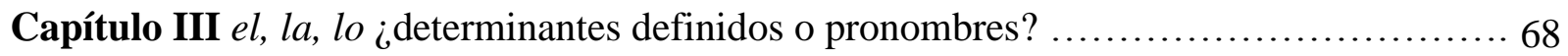

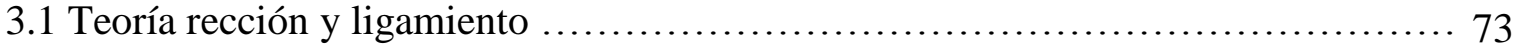

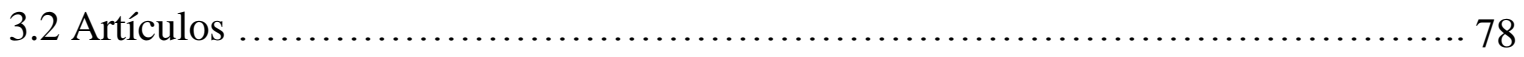

3.2.1 Artículos definidos $e l$, la, lo e Indefinidos un, una ........................ 80

3.2.1.1 El determinante con valor de definitud .............................. 85

3.2.1.2 El determinante con valor de pronombre $\ldots \ldots \ldots \ldots \ldots \ldots \ldots \ldots \ldots \ldots \ldots \ldots$

3.1.2 Fenómenos de definitud y la elección del modo en las cláusulas relativas ........90

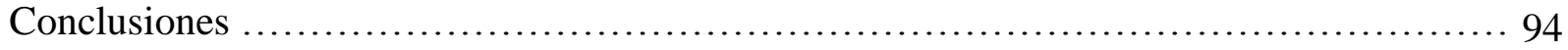

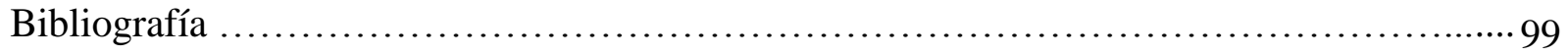




\section{INTRODUCCIÓN}

Las cláusulas de relativo son una de las estructuras más complejas de las lenguas humanas, ya que, de acuerdo a su estructura, su procesamiento supone coindizar: una frase nominal denominada antecedente o cabeza de la relativa, un pronombre relativo que funciona como nexo subordinador el cual se aloja en el Espec del SC y una huella o copia que se encuentra en la posición base de la oración matriz.

El estudio de las cláusulas relativas ha sido uno de los temas más analizados en diversos estudios sintácticos. Las cláusulas relativas son tratadas como cláusulas que funcionan como modificadores nominales.

La gramática tradicional considera que las cláusulas relativas pueden ser clasificadas en dos grupos, según el tipo de incidencia que ejercen en cuanto a la modificación de la frase nominal que las contiene. Brucart (1999), por ejemplo, sostiene que tipológicamente se pueden distinguir dos tipos de cláusulas relativas:

a. La Cláusula relativa restrictiva o especificativa:

Son estructuras cuya función es la de especificar o determinar el elemento de una cláusula principal.

a. El perro $\mathrm{CR}$ [que te mordió] es de Juan.

b. El hombre $\mathrm{CR}$ [a quien María regaló un gato] ha fallecido.

c. El profesor de español tiene un hijo $\mathrm{CR}$ [que trabaja en el hospital].

b. La Cláusula relativa no restrictiva o explicativa:

Son estructuras que pueden servir para hacer algún comentario o para predicar algo de un referente completamente identificado y es menos dependiente de su antecedente. 
a. La casa, cr [que está en la colina], tiene un gran árbol.

b. Juan, CR [quien estudiaba aquí], se graduó.

c. El hombre, CR [a quien vimos ayer], CR [que trajo el paquete], vive en la otra calle.

Las cláusulas relativas se han tratado tradicionalmente como estructuras subordinadas a una oración principal o matriz, la cual delimita la referencia de una frase nominal llamada antecedente, estas estructuras han sido abordadas ampliamente en la literatura, sin embargo, el problema surge cuando hay que analizar las secuencias el que, la que, lo que, los que y las que en estructuras relativas.

No cabe la menor duda que determinar la naturaleza de $e l, l a(s), y l o(s)$ cuyos elementos anteceden a que en estas construcciones relativas parece ser un elemento sin interés por lo que es una cuestión que ha pasado desapercibida para algunos lingüistas que se han detenido a considerar este tipo de construcciones mencionando que se trata de un artículo definido sin mencionar más.

La presente investigación tiene como principal propósito describir y analizar las cláusulas relativas restrictivas enfocándose especialmente en las construcciones que involucran la secuencia $e l, l a(s), l o(s)+q u e$.

En esta investigación abordaré dos temas que, a mi parecer, pueden ser tratados en conjunto pues involucran el mismo fenómeno sintáctico y cada uno puede coadyuvar al análisis y a la explicación de la secuencia $e l, l a(s), l o(s)+q u e$.

El primer tema involucrado tiene que ver propiamente con la secuencia preposición $+e l$, $l a(s), l o(s)+q u e$ con antecedente explícito. Bello (1847) en su gramática argumenta que dichas construcciones deben tratarse como relativos complejos. En estudios posteriores las construcciones el que, la que, y lo que son tratados de manera distinta, en el análisis que 
propone Ojea (1992) la partícula $e l$, la y lo funcionan como determinantes por lo que aparece una categoría vacía (Pro) entre el determinante y el que, donde la categoría vacía (Pro) funciona como el antecedente de que y el núcleo del determinante.

Al igual que Ojea, Brucart (1999) considera a la partícula el, la y lo como un artículo definido donde el que funciona como un pronombre. Las construcciones a las que se hace mención aparecen en (3).
a. Unos libros con los que se entretuvieron.
b. Un hombre al que vi ayer.
c. El cuchillo con el que lo mataron.
d. Una casa en la que vivía.
e. Las calle por las que pasaban en aquellos días.
f. Un mundo en el que ya no cabemos.
g. Una golpiza con la que lo dejaron casi muerto.
h. El hombre sin el que no puede vivir.

Los datos de (3) muestran la secuencia $e l, l a(s), l o(s)+q u e$, estos datos nos hacen cuestionarnos ¿qué tipo de estructura es?, ¿verdaderamente es un relativo compuesto como lo mencionaba Bello en su gramática? ¿cómo se originan las construcciones $e l, l a(s), l o(s)+$ que? ¿es verdaderamente un artículo lo que antecede a que y de ser así por qué siempre es definido?

El segundo tema involucrado son las cláusulas relativas sin antecedente o también llamadas headless relatives, es decir, estructuras relativas donde no hay un antecedente, sin embargo, aparecen al principio de la oración y son construcciones que implican secuencias $e l$, la(s) y $l o(s)+q u e$ como se ejemplifica en las oraciones de (4). 
a. El que esté libre de culpa que aviente la primera piedra.

b. El que llegó es mi hermano.

c. El que trabaja mucho tiene recompensas.

d. La que venga primero será la ganadora.

e. La que llegó con Luis cocina muy bien.

f. Las que venden aquellas mujeres están muy bien.

g. Lo que no me gusta es hacer la tarea la noche anterior.

h. Lo que tú decidas comprar está bien.

i. Los que tengan problemas que los solucionen.

El interés por esta clase de relativas radica en que, mientras las oraciones que tienen un antecedente delimitan la referencia de la frase nominal a la que modifican, no ocurre lo mismo con las oraciones que carecen de un antecedente por lo que se debe cuestionar qué pasa con estas estructuras cuando no lo hay.

Todo el planteamiento y desarrollo de esta tesis de investigación se fundamenta en una interrogante fundamental que da sentido y forma a nuestros temas planteados. Este interrogante es el siguiente: ¿Qué propiedades de las partículas el, la y lo entran en juego en estos diversos contextos para decir que realmente se trata de un artículo determinado lo que antecede al complementante?

La finalidad de esta investigación pretende alcanzar los siguientes objetivos:

En primer lugar, analizar y describir la secuencia $e l$, $l a(s)$ y $l o(s)+q u e$ en las cláusulas relativas restrictivas y demostrar si realmente lo que antecede a que es un artículo definido o no mostrando las propiedades que tiene. 
En segundo lugar, exponer brevemente y dejar abierta la brecha para una nueva investigación que muestre los parámetros sintácticos que determinan el uso de modo indicativo o subjuntivo y la relación que guarda con el empleo de los artículos definidos e indefinidos.

a. Busco el cuchillo con el que se corta el pan.

b. Busco un cuchillo con el que se corte el pan.

c.? Busco el cuchillo con el que se corte el pan.

d. Busco un cuchillo con el que se corta el pan.

Las construcciones mencionadas en (7) son parte de un tema que parece no estar claro y que también involucra la naturaleza del artículo o determinante de la frase nominal antecedente; y que parece afectar el modo de la oración subordinada.

Estas construcciones han sido mencionadas en la literatura especializada, pero queda por aclarar la naturaleza del fenómeno gramatical que subyace esta alternancia entre el modo indicativo y subjuntivo.

La investigación se realizará en el marco de la gramática generativa empleando los trabajos clásicos y los más recientes en el análisis de las cláusulas relativas y los artículos definidos e indefinidos en español, con el fin de indagar como han sido presentadas las cláusulas relativas con la secuencia $e l, l a(s)$ y $l o(s)+q u e$, las cláusulas relativas sin antecedente y abordar los distintos análisis que se han propuesto para estas construcciones y por último cómo ha sido tratado el uso de los determinantes con relación al modo indicativo y subjuntivo de la oración.

Con el fin de alcanzar los objetivos propuestos, partimos de las siguientes hipótesis: 
- $\mathrm{H}_{1}$ : El elemento que el cual introduce cláusulas relativas en español no es un pronombre relativo sino un complementante.

- $\mathrm{H}_{2}$ : Los artículos definidos de la manera en que se relacionan con su contexto se analizan de dos maneras: como determinante fuerte porque funciona como pronombre cuando es anafóricamente dependiente de un antecedente que se recupera por contexto o por una oración previa y como determinante débil cuando no es dependiente de un antecedente porque solo satisface el requisito de unicidad por lo tanto ambos son fonéticamente iguales, pero difieren en su estructura. Esto se tratará en el capítulo 3 apartado 3.2.1.1 y 3.2.1.2

El trabajo se estructura como sigue: en el capítulo I, se abordarán las cláusulas relativas en general mostrando su estructura sintáctica, propiedades, los tipos de relativos que hay en español y las pruebas para determinar a que como complementante, se presentarán los principales análisis que han surgido en torno a este tema. En el capítulo 2, se tratará exclusivamente a las headless relatives haciendo hincapié en los principales análisis propuestos para este tipo de estructuras y por último en el capítulo 3, se desarrollará las propiedades que tienen los artículos definidos y los pronombres para determinar en qué casos el articulo definido puede funcionar como un pronombre y se tratará de forma breve el modo de las cláusulas relativas. 


\section{Capítulo I CLÁUSULAS RELATIVAS}

La descripción sintáctica de las cláusulas relativas siempre ha jugado un papel destacado en las diferentes etapas de la gramática generativa la cual implica el estudio de los componentes de las cláusulas relativas como el tipo de SN que funciona como la cabeza o antecedente de la cláusula relativa, el análisis de la diferencia entre cláusulas relativas restrictivas y apositivas, la función sintáctica de los elementos relativos y por último, qué elementos de la oración principal pueden ser relativizados.

El trabajo de Chomsky (1977) sentó las bases para tratar a las cláusulas relativas como construcciones sometidas al movimiento- $q u$, por lo tanto, las oraciones relativas también son conocidas como palabras- $q u$ al igual que las oraciones interrogativas y exclamativas por lo que se proponen los siguientes rasgos $[ \pm \mathrm{Qu}]$ y $[ \pm$ Preg $]$.

Sintácticamente los elementos interrogativos, exclamativos y relativos se proyectan obligatoriamente a la primera posición de sus oraciones correspondientes en el sintagma complementante o SComp ${ }^{1}$.
a. o [Suj [Luis] sv [no sabe sc [ c [que María se fue $]]]$
b. o [Suj [Luis] Sv [no sabe SC [ Espc [qué hacer]]]].
c. o [Suj [Luis] sv [no sabe sc [ Espc [quién se fue]]]].
d. o [sc [ Espc [iqué se fue María!]]]

\footnotetext{
${ }^{1}$ El nodo Comp es la posición inicial de toda oración principal o subordinada y tiene una doble función: 1. Juega el papel semántico de clasificar una oración en tanto que sea declarativa, interrogativa o relativa.

2. Cumple el papel sintáctico de ser el lugar al que se mueven las partículas interrogativas y relativas desde su posición base hasta el Espc del SC por medio de una transformación denominada movimiento de Qu.
} 
Las cláusulas relativas han sido estudiadas por numerosos lingüistas como: Keenan y Comrie (1977), Cinque (1981), Lehmann (1986), Kayne (1994), Bianchi (1999) entre otros, quienes en sus trabajos han tratado de explicar y dar un análisis a estas construcciones y definir el tipo de antecedente y la función que adquieren dentro de la sintaxis, sin embargo, muchos de estos análisis no satisfacen el problema de las cláusulas relativas.

Las cláusulas relativas (CRs) son estructuras subordinadas a una oración principal o matriz que modifican generalmente a un sintagma nominal denominado antecedente. Este antecedente es un miembro de la cláusula principal, jerárquicamente superior a la cláusula relativa. Un relativo cumple la función de nexo subordinante dentro de la cláusula relativa y tienen un vínculo anafórico con el antecedente, es decir, lo representa en la cláusula relativa de manera que ejerce la función sintáctica que se asignaría al antecedente (Brucart, 1999).

$$
\text { a. o }[[\operatorname{sD~CR}[\ldots]] \ldots . . . \mathrm{sv}[\ldots]]
$$

El esquema de (7) muestra la estructura prototípica de las cláusulas relativas. Lo interesante de estas construcciones es el relativo y su posición dentro de la cláusula matriz o principal, es decir, dependiendo del elemento al que esté modificando será su función sintáctica. El relativo en sí mismo esconde tres propiedades:

- Nexo de subordinación, introduce la cláusula como una oración dependiente a la principal.

- Desempeña una función sintáctica dentro de la cláusula misma, puede ser sujeto, objeto directo, objeto indirecto.

- Función anafórica la cual permite relacionar semánticamente la cabeza de la cláusula relativa y el antecedente. 
Las cláusulas relativas se analizan comúnmente considerando dos rasgos estructurales:

1. La función sintáctica del antecedente en la oración principal.

2. La función sintáctica del relativo que representa al antecedente dentro de la cláusula relativa.

Para algunos lingüistas las cláusulas relativas tienen una relación categorial con los adjetivos pues desempeñan respectivamente las mismas funciones con respecto a su antecedente $^{2}$.
a. La casa vieja se derrumbó.
b. La casa que es vieja se derrumbó.

En la oración (8a) el adjetivo "vieja" nos permite limitar a la FN la casa y excluir a todas aquellas que no tengan la cualidad de ser viejas, es decir, delimita al referente, mientras que en (8b) la cláusula relativa nos permite identificar la FN la casa, lo mismo que pasa en (8a) sin embargo, la FN ha participado en dos eventos por un lado la casa es vieja y por otro la casa se derrumbó.

\subsection{CRs restrictivas con antecedente vs CRs explicativas}

Una cláusula relativa es una construcción que consiste de un nominal y una cláusula subordinada interpretada como la que modifica atributivamente al nominal y delimita su

\footnotetext{
${ }^{2}$ El adjetivo al modificar al nombre, lo hace de dos formas distintas: lo determina, por un lado, es decir, lo especifica limitando su extensión; y por otro, lo describe, o sea, lo explica aumentando su intensión, al añadirle información a algo ya determinado.
} 
referencia, Andrews (2007). Este nominal es conocido como la cabeza de la cláusula subordinada. La frase nominal modificada es un elemento de la oración principal, pero también tiene una función gramatical dentro de la cláusula relativa, Lehmann (1984).

Las oraciones subordinadas relativas admiten dos variantes que dependen de la forma en que la oración ejerce su función modificadora.

a. El hombre $\mathrm{CR}$ [que trajo el regalo] es mi tío.

b. El jardín, CR [que está abandonado], [que transmite paz], es enorme.

En (9) se muestran los dos tipos de oraciones subordinadas relativas en español. En (9a) aparece una relativa restrictiva o especificativa, mientras que en (9b) se trata de una relativa explicativa o apositiva.

La diferencia entre ambas radica en que las restrictivas se encuentran en el SD y brindan información determinante o esencial, generalmente reduciendo el rango de posibles referentes de la frase nominal como se muestra en la estructura de (10a) y las explicativas, en cambio, se alojan en la SN y agregan cierta información, pero no restringen la denotación del grupo nominal y se puede prescindir de ellas como se puede observar en el árbol sintáctico de (10b).

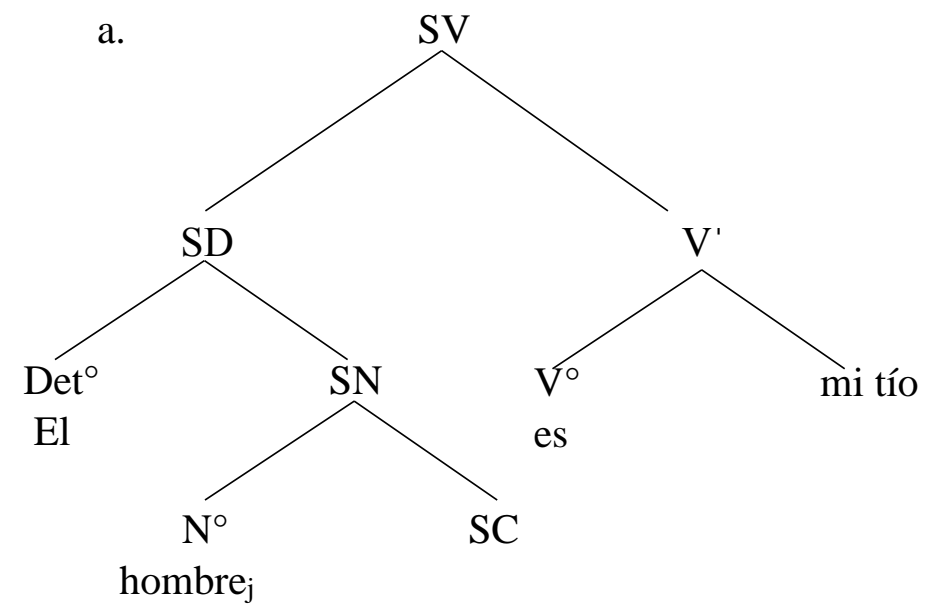



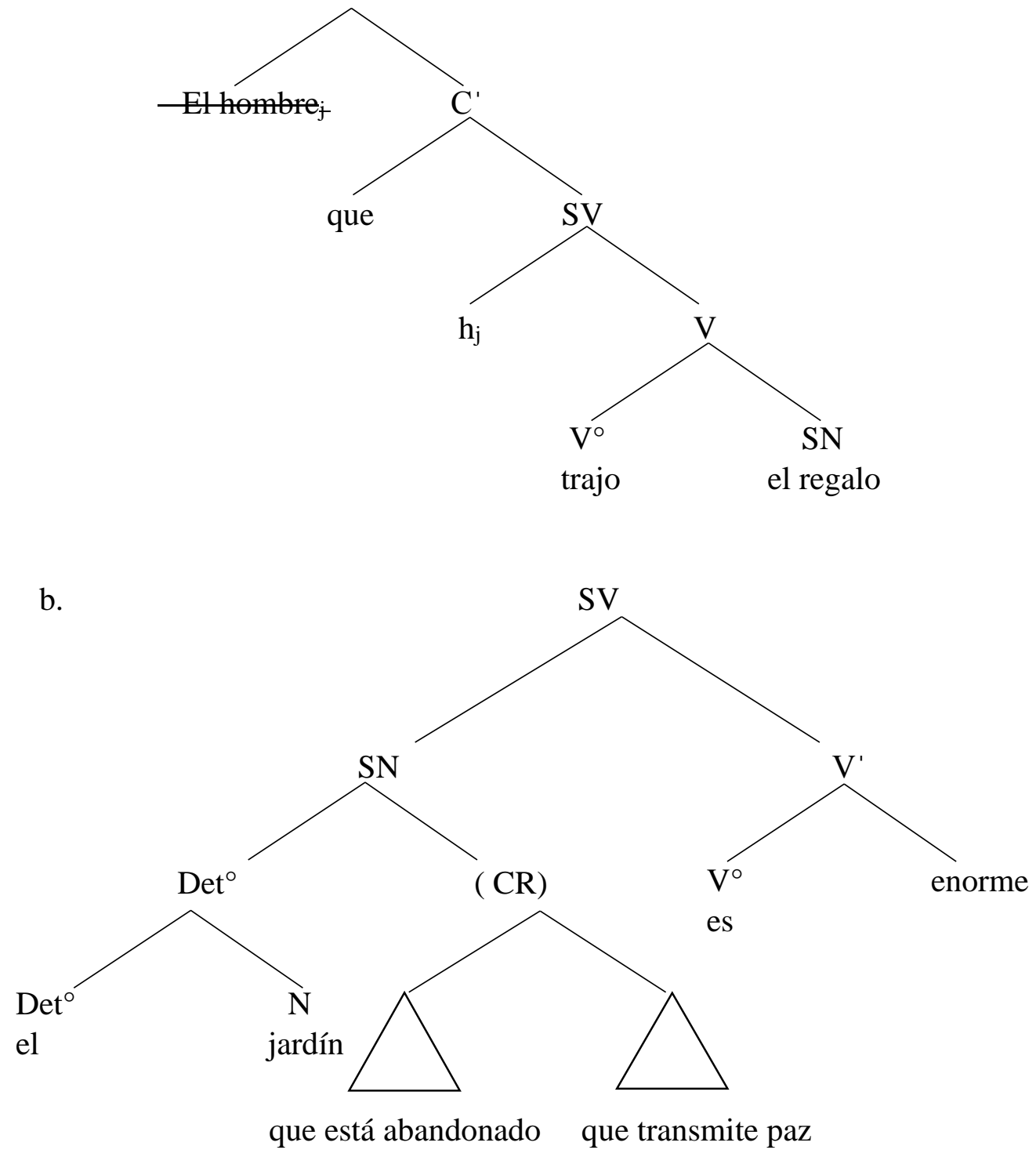

\subsubsection{Propiedades}

La función de las cláusulas relativas restrictivas es delimitar o determinar su antecedente, es decir, el núcleo nominal que se encuentra en la oración matriz o principal construyendo una sola oración compuesta por una principal y una subordinada relativa. 
La función de las cláusulas relativas no restrictivas es no especificar o determinar el núcleo nominal, sino ofrecer una explicación adicional acerca del antecedente y podemos tener incrustadas más de una cláusula relativa.

a. Los alumnos $\mathrm{CR}$ [que no vinieron] reprobarán.

b. El joven, CR [que imparte clases], CR [que vive lejos], no vendrá hoy.

En (11a) la cláusula relativa restrictiva delimita al referente y es dependiente de él, mientras que en (11b) las dos cláusulas relativas que aparecen solo sirven para completar el significado de quien se habla y no son dependientes de su antecedente ya que solo agregan información adicional de él.

Las cláusulas relativas restrictivas son modificadores que precisan la denotación del grupo nominal del que forman parte, mientras que las explicativas son modificadores que se agregan a modo de incisos y son menos dependientes de su antecedente que las primeras. Como consecuencia de ello, se pueden omitir a menudo sin que resulten afectadas las condiciones de verdad del resto del enunciado. Por ejemplo, si a las oraciones que aparecen en (11) les suprimimos las cláusulas relativas que componen su estructura nos quedaría oraciones como las de (12).
a. Los alumnos que no vinieren reprobaran.
b. El joven, que imparte clases, que vive lejos, no vendrá hoy.

Si comparamos las oraciones de (11) con las de (12) tendríamos que en la oración de (12a) todos los alumnos serán reprobados, sin embargo, en (11a) la función del relativo es especificar quienes serán reprobados. En (12b) el joven no vendrá hoy tendremos la 
interpretación que es cualquier joven si no tenemos más información de él, en cambio en (11b) las cláusulas relativas agregan información pertinente para saber de quién se habla.

La interpretación de una cláusula relativa se obtiene a través de la asociación del relativo, su antecedente y de su posición básica (huella o copia), para que una cláusula relativa esté bien formada, es necesario que el relativo, el antecedente y la posición básica tengan el mismo índice en algún nivel de representación.

Chomsky (1982), Cinque (1982) y otros lingüistas establecen que debe haber tres elementos que deben ser coindizados: el antecedente, el operador relativo y el elemento que está en la posición base.

a. El antecedente de la cláusula relativa

El antecedente es la frase nominal en la cláusula principal que está modificada por la oración relativa.

a. Suj [ANT [El señor] CR [que me atendió]] sv [fue pvo [muy amable]].

b. suj [La casa] sv [tiene oD [ANT [un jardín] CR [que trasmite alegría]].

En las oraciones de (13) las funciones gramaticales de sujeto y de objeto directo, respectivamente, que presenta la frase nominal relativizada de cada una de las oraciones, pueden fácilmente suponerse debido a la concordancia que aparece en la marcación verbal por lo que un antecedente de una cláusula relativa puede estar en función de sujeto, objeto directo, también hay que hacer hincapié en que no solo podemos encontrar al antecedente en las dos funciones gramaticales ya mencionadas sino que también pueden encontrarse dentro del objeto indirecto y dentro de un complemento circunstancial o adjunto como se muestra respectivamente en (14). 
a. suj [Juan] sv [envió od [la carta] or [para [ANT [la empresa] CR [que lo contrató]].

b. sus [Luis] sv [compró la casa] CCL [en ANT [la playa] CR [que está en Cozumel].

b. Operador relativo

Es el elemento que relaciona la cláusula relativa con la cláusula principal y la subordina a ella. Como se ha dicho anteriormente, los pronombres relativos tienen una función anafórica que permiten recuperar ciertas características semánticas y gramaticales de la frase nominal relativizada. Como en español y otras lenguas, muchos de los pronombres relativos como quien, cual, etc. permiten expresar la función gramatical que desempeña la frase nominal relativizada dentro de la cláusula relativa, que no es pronombre relativo sino un complementante por lo que no puede ser argumento de la oración subordinada (para más detalle véase el punto 1.1.2.1), sin embargo, se trata dentro de la categoría de las cláusulas relativas.
a. El hombre de REL [quien] me enamoré es una ilusión.
b. Juan es el maestro a REL [quien] todo mundo quiere.
c. El lápiz con el REL [cual] escribes cartas se perdió.
d. María tiene un hermano сомP [que] vive en EE.UU.
e. El niño сомp [que] se cayó se ha fracturado la pierna.

Las oraciones de (15) muestran cómo el relativo es el elemento que introduce la cláusula relativa y si es pronombre como en (15a), (15b) y (15c) desempeñará una función anafórica que expresa ciertas características semánticas o ciertas propiedades gramaticales de la frase nominal relativizada, mientras que en $(15 \mathrm{~d})$ y $(15 \mathrm{e})$ se trata de un complementante por lo que 
no debe ser considerado un pronombre relativo, sino más bien un nexo subordinador sin contenido semántico y sin valor referencial o anafórico.

c. Elemento en la posición base

Es el elemento que se origina en la posición base dentro de la oración que hace referencia a la frase nominal antecedente por lo que debe estar coindizada con el antecedente y el relativizador si este se trata de un pronombre relativo como quien.

a. sUJ [El hombre $\mathrm{j}_{\mathrm{CR}}$ [a quien ellos golpearon aquien $\left._{\mathrm{j}}\right]$ sv [tiene oD [fracturas]].

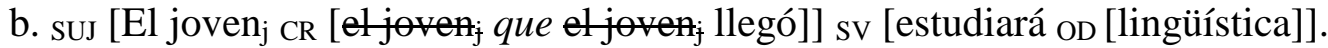

a. SUJ [DET [El profesor ${ }_{\mathrm{j}} \mathrm{CR}\left[\mathrm{a}\right.$ quien $_{\mathrm{j}} \mathrm{sv}[$ tú admiras quien $\left.\left.\mathrm{j}]\right]\right]$ sv [se ha ido].

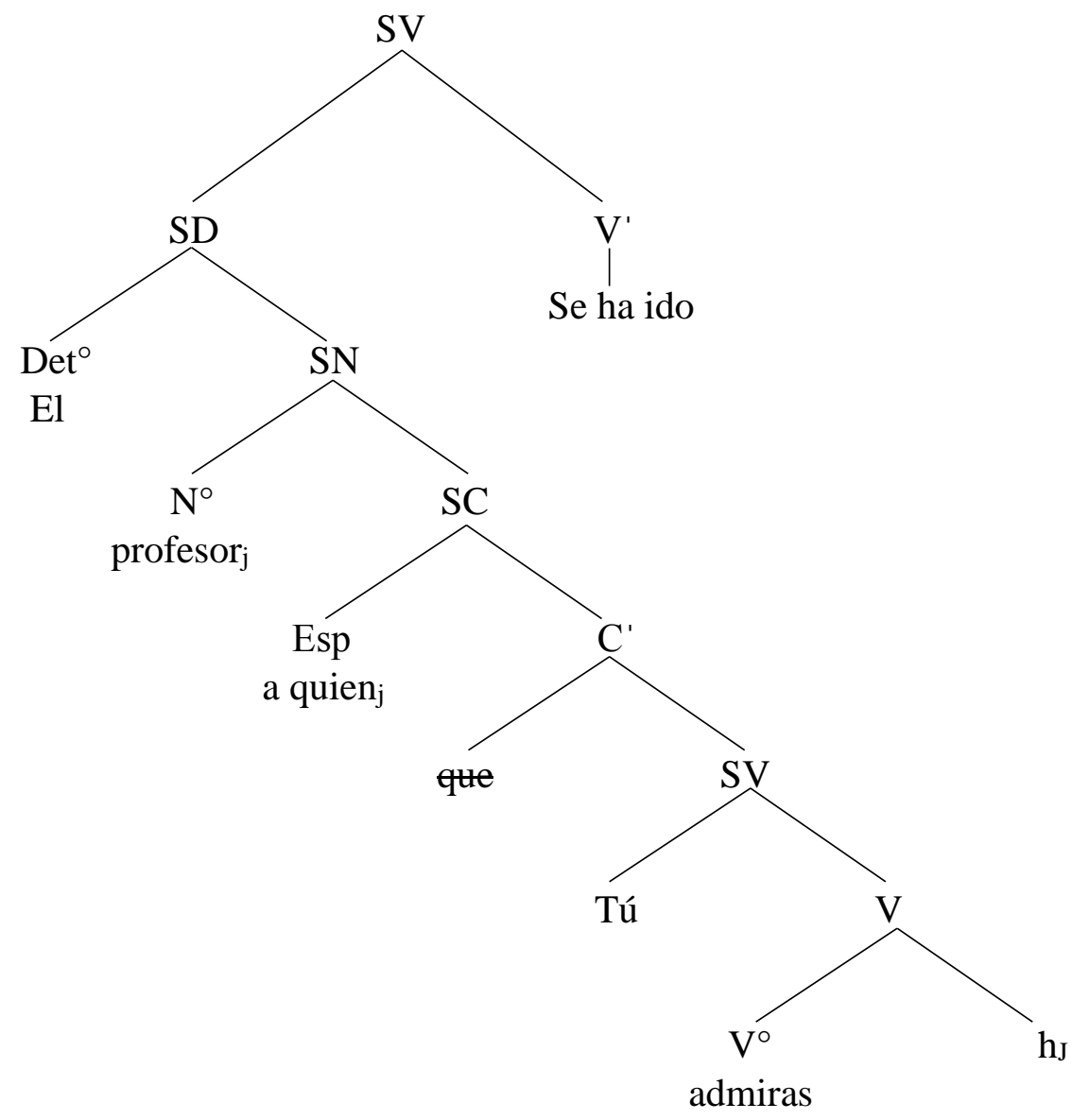




\subsubsection{Tipos de elementos relativizadores}

El elemento relativizador se utiliza para designar dos clases de unidades:

a. Un paradigma de formas gramaticales compuestos por los pronombres (quien y cual), el complementante (que) y un adjetivo determinativo $\left(\right.$ cuyo $\left.{ }^{3}\right)$.

b. Las oraciones subordinadas introducidas por los elementos relativos.

La relación que hay entre ambas es de implicación mutua, por un lado, las cláusulas relativas necesitan un nexo que las introduzca y, por otro lado, los elementos relativos solo pueden aparecer dentro de un elemento de una oración principal para que pueda subordinarse.

Según Brucart (1992), el núcleo $C^{\circ}$ de las oraciones subordinadas (relativas y completivas interrogativas y afirmativas) tiene el rasgo [QU-], que indica dependencia o subordinación. Los relativos e interrogativos comparten este rasgo léxico, que se coteja en el especificador del núcleo $\mathrm{C}^{\circ}$. Los relativos se diferencian de los interrogativos en que los primeros poseen, además, el rasgo [+Rel].

a.

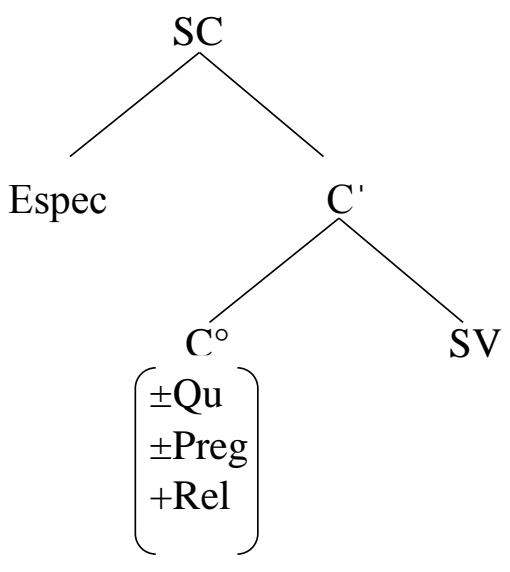

\footnotetext{
${ }^{3}$ Cuyo se incluye en la categoría de los adjetivos determinativos, ya que actúa como determinante de un núcleo nominal y tiene significado de posesión, para más información véase RAE: Diccionario panhispánico de dudas. Madrid: Santillana, 2005, p. 202.
} 
Los elementos relativizadores se alojan en la misma posición a la cual se mueven los elementos interrogativos y exclamativos por lo que podrían confundirse claramente, sin embargo, la propiedad que los distingue es que los elementos relativizadores desarrollan un doble cometido en la oración que encabezan. Además de ser nexos de subordinación, funcionan como argumentos de la subordinada, cumpliendo en ella la correspondiente función gramatical ${ }^{4}$.
a. ¿quéj compraste quééj?
b. *que compré es muy interesante.
c. ¿quién $n_{x}$ quién $x_{x}$ compró un libro?
d. *a quien le hablamos nunca llega tarde.
e. ¿Cuál $l_{i}$ es difícil cuáli $l_{i}$ ?
f. *El cual escribe muy bien se rompió.

Como se puede observar en las oraciones de (19) los elementos interrogativos y relativos se parecen. Sin embargo, los elementos interrogativos son un argumento de la oración principal como se muestra en las oraciones de (19a), (19c) y (19e), mientras que las oraciones con un elemento relativo deben tener una cabeza o antecedente situado en la oración matriz o principal para que puedan aparecer ${ }^{5}$.

\footnotetext{
${ }^{4}$ Solo si se trata de los pronombres relativos quien y cual.

${ }^{5}$ Salvo el caso del pronombre relativo quien el cual puede aparecer sin antecedente.
} 


\subsubsection{Quien}

El comportamiento sintáctico del pronombre relativo quien está fuertemente condicionado por su característica léxica [+ Humano], lo que explica por qué siempre debe estar precedido por la preposición $a$ cuando funciona como objeto directo u objeto indirecto.

a. Los niños a quienes Pedro regañó tienen miedo.

b. Los niños a quienes Pedro regaló dulces están enfermos.

Las oraciones de (20) muestran el comportamiento sintáctico del pronombre relativo quien. En (20a) la función sintáctica de este pronombre es de ser un argumento del verbo subordinado por lo que cumple la función de objeto directo, mientras que en (20b) la función que tiene es la de objeto indirecto.

Al ser pronombre tiene marca de número como lo ejemplifican las oraciones en (21a). No exhibe marca de género, sin embargo, se codifica por medio del antecedente al que se refiera así en (21b) quienes será femenino al ser su antecedente una FN cuyo núcleo es femenino, mientras que en (21c) será masculino.

a. Juan es a quien mandé un regalo. / Los jóvenes a quienes dieron una medalla.

b. Las alumnas ${ }_{\mathrm{j}}$ a quienes $\mathrm{j}_{\mathrm{j}}$ tienen que felicitar tienen promedio de excelencia.

c. El profesor a $_{\text {quien }}$ agradecieron por su labor no llegó al evento.

Una característica importante de este relativo es que puede ocurrir sin antecedente como se muestra a continuación en (22).

a. Quien bien te quiere no te hace sufrir. 
b. Quienes apoyaban la huelga han desaparecido.

c. Quien hace ejercicio siempre está activo.

Al ser un pronombre relativo quien ocupa la posición del especificador dentro del sintagma complementante. La estructura prototípica de las cláusulas relativas con antecedente aparece en (23a) y las estructura de las que no aparece en (23b)
a. $\left[\operatorname{ANTj}\left[\mathrm{CR}\left[\ldots\right.\right.\right.$ quien $\left.\left._{\mathrm{j}} \ldots \mathrm{h}_{\mathrm{j}}\right]\right]$
b. $\mathrm{CR}\left[\right.$ quien $\left._{\mathrm{j}} \ldots \mathrm{h}_{\mathrm{j}}\right]$

Como ya se hizo mención en párrafos anteriores, los elementos que integran una cláusula relativa (el antecedente, el pronombre relativo y la posición de origen) deben estar coindizados; como se ejemplificó en (18a).

\subsubsection{Cual}

El pronombre relativo cual se caracteriza por tener una menor autonomía referencial a diferencia del pronombre quien. Por lo tanto, siempre debe tener un antecedente explícito, lo que implica que esta forma no puede ocurrir en cláusulas relativas sin antecedente.
a. El bolígrafo con el cual escribiste la carta se perdió.
b. La actriz a la cual vimos anoche ha ganado un Óscar.
c. * El cual llegó es mi hermano.

El pronombre relativo cual no está completo en cuanto a su valor pronominal por lo que necesita del artículo definido para satisfacer este rasgo. 
Brucart (1999) hace referencia a algunas características que distinguen nítidamente el relativo el cual del resto de los relativos: morfológicamente, se trata de una entidad dotada de flexión de número como en la oración de (25a), no tiene género por lo que el artículo definido satisface esta ausencia como se muestra en (25b) haciendo completa su naturaleza de pronombre ${ }^{6}$.
a. Los años en los cuales fuimos felices $\mathrm{h}_{\mathrm{j}}$ se han ido.
b. Regresamos a la playa $a_{x}$ en la cual $_{\mathrm{x}}$ pasamos bellos momentos $\mathrm{h}_{\mathrm{x}}$.

La estructura prototípica de este tipo de relativo aparece en (26a) donde el cual se aloja en el Espec del SC.

a. [ANT x ...DET $\left[\mathrm{el}\right.$ REL $\left[\mathrm{cual}_{\mathrm{x}} \ldots \mathrm{h}_{\mathrm{x}}\right]$

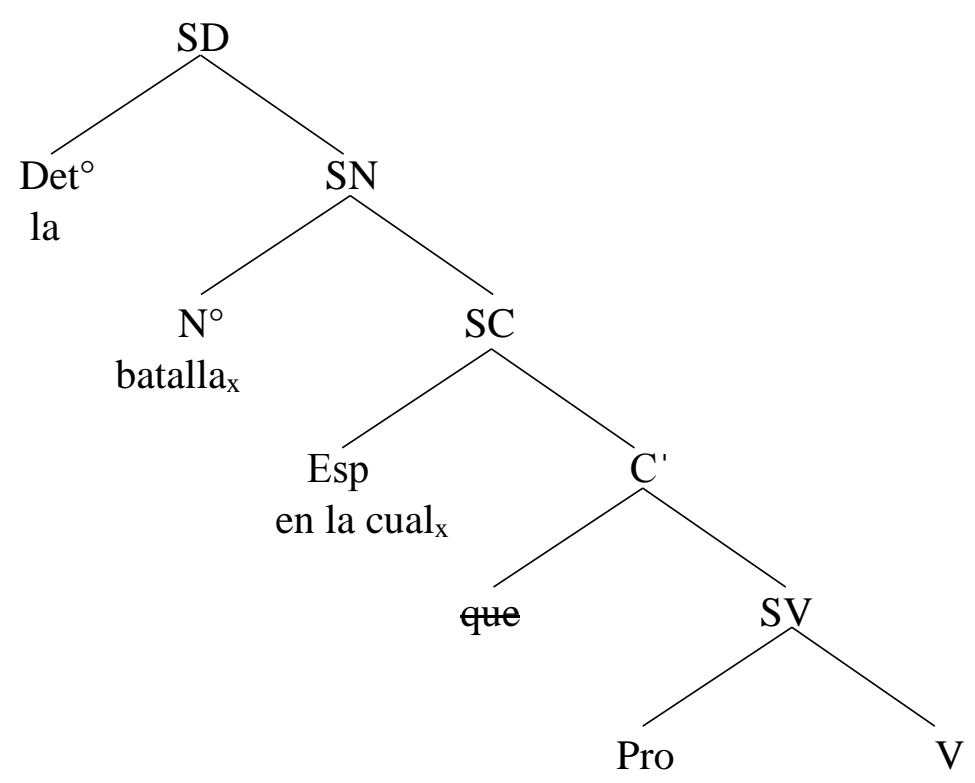

\footnotetext{
${ }^{6}$ Este pronombre relativo es diferente a que, puede mostrar características similares en su estructura al usar un artículo definido (el que, la(s) que y lo(s) que). Sin embargo, su estructura es diferente ya que que no es un pronombre por lo que no puede ser tratado de manera similar o igual.
} 


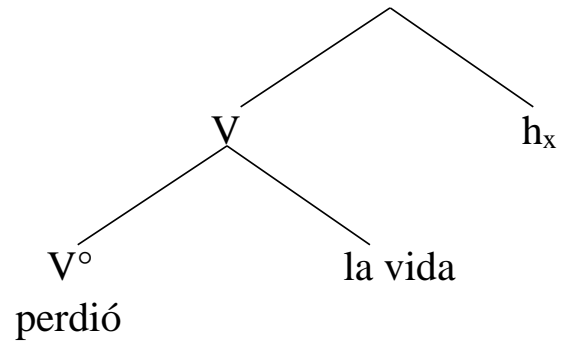

\subsubsection{Que}

La gramática tradicional considera al elemento que de las subordinadas relativas como pronombre, Chomsky en Estructuras Sintácticas (1957) asumía esta postura. Más tarde (1982) propone que el pronombre relativo "que" es semánticamente vacío, por lo tanto, el valor de la variable tiene que fijarse por el antecedente, y se necesita enlazar el pronombre relativo con el SN y se "coindizan" bajo la regla de la predicación. La interpretación del pronombre relativo se obtiene a través de la regla de "coindización" donde el antecedente y el relativo tienen el mismo índice.

a. suj [La bomba ${ }_{\mathrm{x}} \mathrm{CR}\left[q u e_{\mathrm{x}}\left[\right.\right.$ Pro estalló $\left.\left.\left.\mathrm{h}_{\mathrm{x}}\right]\right]\right]$ sv [dejó muchos muertos].

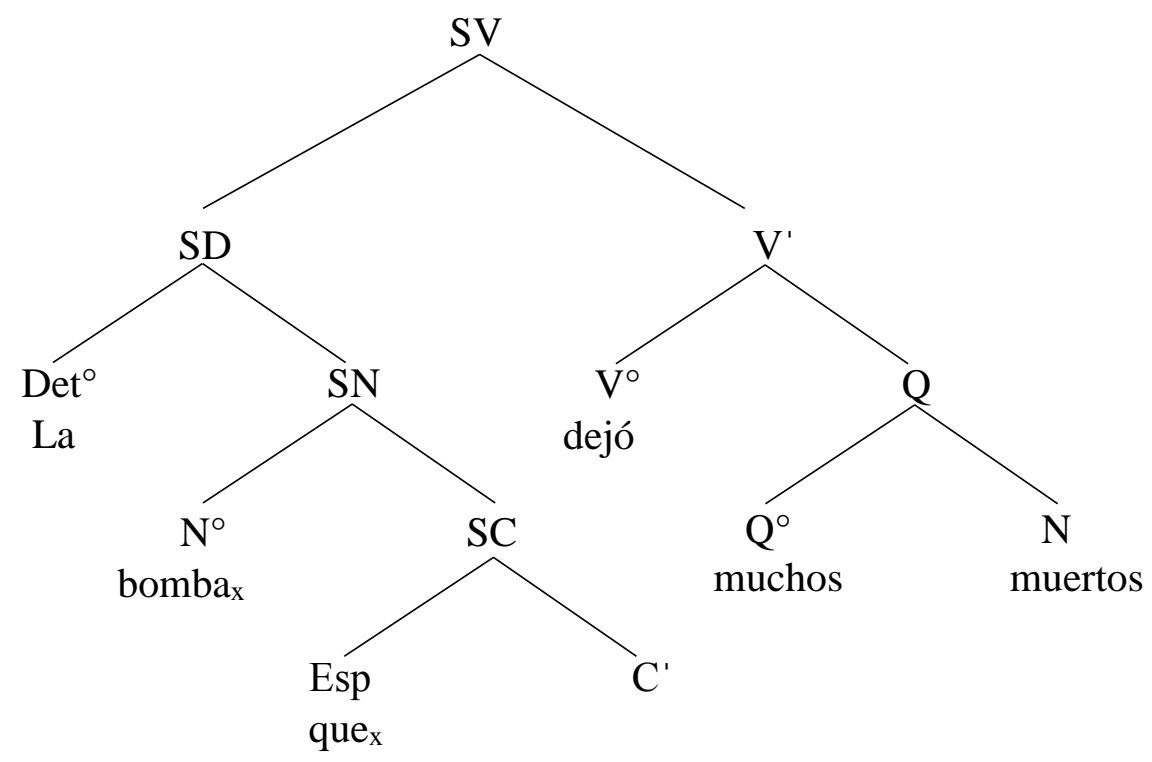




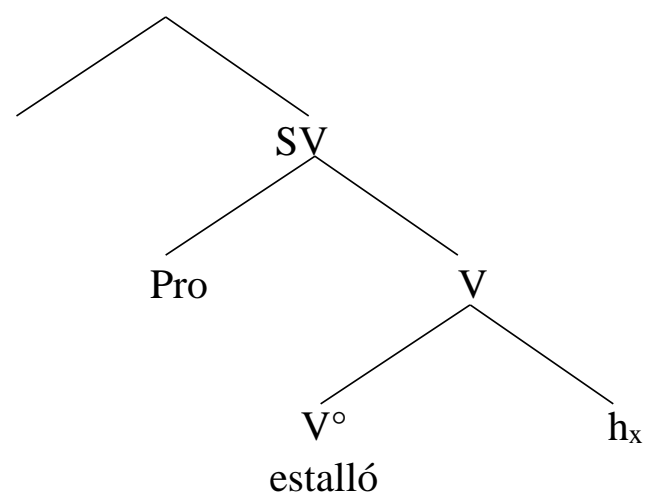

Para Brucart (1999) que sigue siendo un pronombre relativo no marcado, puede desarrollar cualquier función sintáctica y carece de rasgos léxicos y flexivos, mientras que para Rivero (1980, 1982) la partícula que posee dos categorías distintas: la primera, que es un complementante, es decir, es un elemento del lexicón, un morfema de la lengua, que se inserta de manera facultativa en la posición dominada por \pm Qu en el nodo COMP. La segunda, que es un pronombre relativo cuando es un constituyente de un sintagma prepositivo. Sin embargo, análisis posteriores han revisado esta cuestión y concluido que este elemento no es un pronombre relativo sino más bien un nexo subordinador sin contenido semántico, sin valor referencial o anafórico.

Como sucede en muchas otras lenguas, este relativizador es formalmente idéntico al complementante que introduce las cláusulas subordinadas completivas ${ }^{7}$ como se muestra a continuación en (28).

a. El niño $\mathrm{CR}$ [que conoces] vive aquí.

\footnotetext{
${ }^{7}$ No se hará mucho hincapié en el análisis de los diferentes que del español, pero se puede concluir que tiene un único valor lingüístico que es ser marca de subordinación con dos usos diferentes contextuales, por un lado introduce oraciones subordinadas completivas y por otro cláusulas relativas.
} 
b. Dice osc [que el niño] vive aquí.

El elemento que que ha sido tratado como pronombre relativo presenta diferencias importantes que lo distinguen de los pronombres tanto relativos como personales. A continuación, se presentan algunos parámetros que ayudan a determinar por qué debe ser tratado como un complementante y no como un pronombre relativo.

1. Caso gramatical

El caso es una categoría abstracta postulada por la gramática generativa para todas las lenguas. La teoría del caso explica como el sintagma nominal y los pronombres reciben una y solo una interpretación semántica a instancias de un asignador de caso como los verbos o las preposiciones, lo cual permite reconocer su función dentro de la oración.
a. Él quiere que vaya. Caso nominativo.
b. La compró en la tienda. Caso acusativo
c. Le dijo muchas mentiras. Caso dativo
d. Quien haya traído la tarea tiene un punto extra. Caso nominativo
e. Jesús vio a quien rompió la ventana. Caso acusativo
f. María le dará una invitación a quien llegue primero. Caso dativo
g. El profesor que impartía clases de español está jubilado.

Como se muestra en la oración $(29 \mathrm{~g})$ que no refleja caso como lo hacen los pronombres y el pronombre relativo quien como se muestra en los ejemplos de (29a-f).

\section{El género}

Es una propiedad gramatical de los sustantivos y de algunos pronombres, en español no existe el género neutro por lo que solo tenemos masculino (no marcado) y femenino (marcado). 

a. Él es valiente / Ella no lo es.
b. María es a quien regalamos un pastel / Juan es a quien María golpeó.
c. El niño que tiene el perrito / La niña que tiene el moño.

Los pronombres siempre presentan marcas de género como es el caso de los ejemplos en las oraciones de (30a) masculino y femenino respectivamente, en lo ejemplos de (30b) el pronombre relativo quien no tiene género por sí mismo, sin embargo, el antecedente es el que indica si se trata de género masculino o femenino, mientras que las oraciones de (30c) que no tiene género al no tener un antecedente como los pronombres.

\section{Número}

Es una propiedad gramatical característica de los sustantivos, los pronombres, adjetivos, determinantes y verbos ${ }^{8}$.

Este rasgo se codifica de dos formas: singular (alude a una sola entidad de un conjunto) y plural (alude a más de una entidad de un conjunto).
a. Él viajó desde Madrid / Ellos no saben nada de la vida.
b. Quien llegue temprano será el ganador / Juan golpeó a quienes le aventaron la piedra
c. El hombre que ganó la lotería / *Los niños ques vinieron de España.

\section{Presencia del artículo}

\footnotetext{
${ }^{8}$ La codificación de número en los verbos se obtiene a través de la desinencia del verbo y por concordancia con el sujeto:

Los niños traerán dulces

El niño traerá dulces.
} 
A veces, la estructura sintáctica de los nominales requiere de un artículo para poder coocurrir como argumento de un verbo. Sin embargo, a diferencia de los nominales, los pronombres no van con artículo
a. El perro / La gata
b. *El él /* La ella

El que coocurre (superficialmente) con artículos como en (33a), mientras que el pronombre quien no lo permite como se muestra en (33b)
a. El que llegó es mi hermano.
b. *El quien llegó es mi hermano.

5. Presencia de la a de acusativo

Los nombres de humano y los pronombres relativos a humanos (no clíticos) exhiben como objetos directos la preposición $a$ de acusativo. El que no permite la preposición $a$ de acusativo porque no es nombre o pronombre, ni tiene referente humano ni de ningún tipo véase los ejemplos en (34).
a. Vio a un hombre. / Vio un hombre.
b. Lo vio a él. / Juan vio a él.
c. El hombre a quien Juan vio llegar.
d. *El hombre a que Juan golpeó.

6. Coordinación de pronombres. 
Los pronombres pueden coordinarse como se muestran en (35a), el pronombre relativo quien también puede ser coordinado como en (35b), pero el que no puede ser coordinado y resulta agramatical por no ser considerado un pronombre.
a. Estábamos hablando de él y con él.
b. La persona de quien y con quien estábamos hablando.
c. *La persona de que y con que estábamos hablando.

Cada una de las pruebas que se presentaron nos permiten analizar a que como un complementante y rechazar la idea de tratarlo como un pronombre relativo.

Como se puede observar el meollo en estas construcciones con el complementante que consiste en determinar que no es un pronombre como los otros elementos relativos como quien y el cual por lo que solo se mantiene la relación de insertar o introducir cláusulas relativas en la oración matriz.

La estructura prototípica que se ha propuesto desde el primer análisis de estas construcciones es la que aparece en (36a) donde el que es un elemento pronominal y por lo tanto debe tener una función sintáctica y se alojaba en el Espec del SC.

a. $\left[\right.$ ANTx CR $\left[\right.$ que $\left._{\mathrm{x}} \ldots \mathrm{h}_{\mathrm{x}}\right]$

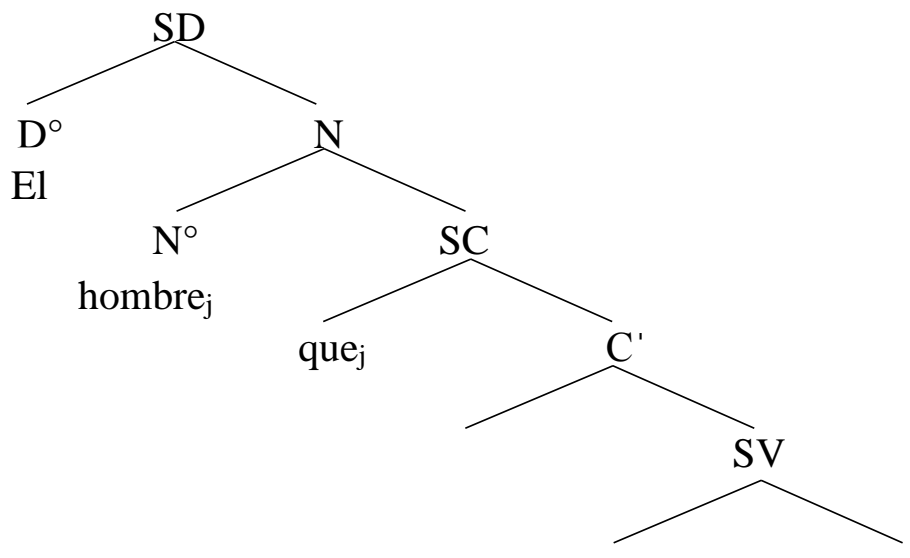




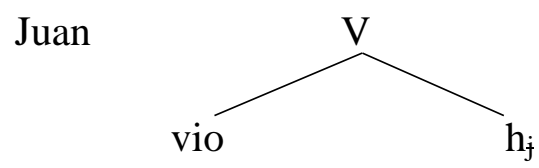

Siguiendo esta idea sobre el que como pronombre a pesar de no tener rasgos $\phi^{9}$ acepta como antecedentes sustantivos de cualquier género, número y pronombres de cualquier persona. Dentro de la cláusula que encabeza puede funcionar como sujeto, objeto directo, objeto indirecto, complemento o adjunto, ya que adquiere la categoría a la que pertenece su antecedente y por ende ejerce las mismas funciones como se ejemplifica en (37).
a. suj [Las flores $\mathrm{x}_{\mathrm{CR}}\left[q u e_{\mathrm{x}}\right.$ me regaló $\mathrm{h}_{\mathrm{x}}$ Jesús]] sv [se secaron].
b. suj[Juan] sv [despidió oD [a la secretaría $\mathrm{CR}_{\mathrm{CR}}\left[q u e_{\mathrm{j}} \mathrm{h}_{\mathrm{j}}\right.$ tiene dos hijos]]].
c. suJ $\left[\right.$ La casa $a_{\mathrm{CR}}\left[q u e_{\mathrm{i}}\right.$ compró $\mathrm{h}_{\mathrm{i}}$ mi amigo]]] sv [es enorme].

Ahora bien, dado los parámetros que indican que que no juega el papel de un pronombre sino un complementante se tiene una estructura diferente a la que se presentó en (36a) donde estaba coindizado con el antecedente y la posición de origen. En (38) se muestra la estructura de que como complementante donde no estará coindizado con ningún elemento de la oración subordinada y no cumplirá el papel de algún argumento del verbo, sino que solo encabezará cláusulas relativas.
a. $\left[\operatorname{ANTx} \mathrm{CR}\left[\mathrm{h}_{\mathrm{x}}\right.\right.$ que $\left.\mathrm{h}_{\mathrm{x}}\right]$

La estructura de (38) consiste en representar la frase nominal relativizada por medio de una huella coindizada con el antecedente. El contexto lingüístico permite al hablante suponer el

\footnotetext{
${ }^{9}$ Los rasgos phi aluden a género, número y persona.
} 
lugar que la frase nominal relativizada ocuparía dentro de la oración relativa. Es decir, el contexto de la oración permite reconstruir la función gramatical que desempeña la frase nominal relativizada dentro de la cláusula relativa, aunque esta no aparezca realmente en ella, como en los siguientes ejemplos.

a. Suj [La policía] sv [detuvo oD [al hombre $\mathrm{x}_{\mathrm{CR}}$ [el hømbre ${ }_{\mathrm{x}} q u e \mathrm{~h}_{\mathrm{x}}$ portaba droga]]].

b. Suj $_{\text {[La persona }}\left[\right.$ [la persena $q$ que atropellaron $\left.\mathrm{h}_{\mathrm{j}}\right]$ ] [ha muerto].

Las funciones gramaticales de sujeto y de objeto directo, respectivamente, que presenta la frase nominal relativizada de cada una de las oraciones anteriores, pueden fácilmente suponerse debido a la concordancia que aparece en la marcación verbal.

Ahora bien, qué pasa con estas oraciones que muestran otra estructura diferente a la conocida donde se involucra la presencia de un elemento que parece ser un artículo determinado.
a. Unos libros con los que se entretuvieron.
b. Un hombre al que vi ayer.
c. El cuchillo con el que lo mataron.
d. Una casa en la que vivía.
e. Las calle por las que pasaban en aquellos días.
f. Un mundo en el que ya no cabemos.
g. Una golpiza con la que lo dejaron casi muerto.
h. El hombre sin el que no puede vivir.

Las cláusulas de relativo con antecedente explícito formadas por la combinación artículo + que han suscitado varias propuestas interpretativas a lo largo de la tradición gramatical. Los 
lingüistas que han abordado estas construcciones han desencadenado diversos puntos de vista e interpretaciones que demuestran la complejidad estructural que alberga este tipo de relativas.

Como brevemente se ha tratado al inicio de este apartado, una primera interpretación propuesta por Bello (1847) en su gramática argumenta que dichas construcciones deben tratarse como relativos complejos, es decir, como una sola unidad por lo que en un análisis tendríamos algo como (40).

a. sUJ [El librox CR [con [el que $]$ estudiaste $\left.\left.\mathrm{h}_{\mathrm{x}}\right]\right]$ sv [tiene oD [errores ortográficos]].

En estudios posteriores las construcciones el que, la que, y lo que son tratados de manera distinta, en el análisis que propone Ojea (1992) la partícula el, la y lo funcionan como determinantes por lo que aparece una categoría vacía (Pro) entre el determinante y el que, donde la categoría vacía (Pro) funciona como el antecedente de que y el núcleo del determinante.

a. sUJ [La iglesia $\mathrm{a}_{\mathrm{j}}$ CR [a DET [la $\left.{ }_{\mathrm{N}}\left[\mathrm{Pro}_{\mathrm{j}}\right]\right] q u e_{\mathrm{j}}$ fuimos ayer $\left.\left.\mathrm{h}_{\mathrm{j}}\right]\right] \mathrm{sv}$ [era muy bonita]. Al igual que Ojea, Brucart (1999) considera la partícula el, la y lo como un artículo definido que determina el género y número del $\mathrm{N}$ en este caso que funciona como un pronombre.

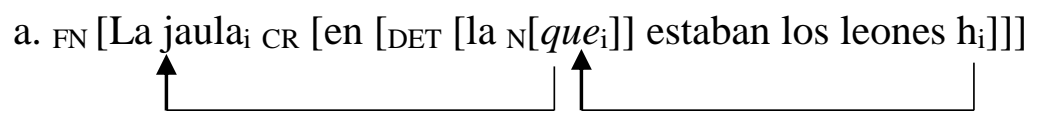


Las propuestas de análisis antes mencionadas dan pauta para presentar un nuevo análisis donde el elemento que antecede al complementante que funciona como un elemento pronominal.

\subsubsection{Análisis}

Los trabajos más destacados sobre el análisis de las cláusulas relativas tienen que ver con el tipo de antecedente, la posición de origen y la coindización entre los elementos relativos y la interpretación de la identidad referencial entre el relativo y su antecedente.

La estructura de las oraciones de relativo se ha discutido durante años en el marco de la Gramática Generativa y se han propuesto varios análisis sintácticos empezando por el análisis que propone Chomsky en el 57 donde que funciona como un pronombre relativo y se mueve al SC, estudios posteriores al de Chomsky tratan al que como un complementante.

\subsubsection{Que pronombre y movimiento a SC}

El trabajo de Estructuras sintácticas de Chomsky (1957) propone la existencia de un dispositivo mental abstracto que puede generar cualquier frase de cualquier lengua natural (L) mediante la conexión de sonidos y significados que tiene dos componentes:

a. Componente sintáctico:

Posee una base y un componente transformacional. La base, a su vez, posee un componente categorial y un lexicón (Chomsky, 1970). En términos simples, el lexicón es un diccionario mental. En términos técnicos, es un conjunto inordenado de entradas léxicas que contienen 
información sintáctica, semántica y fonológica, representada mediante una especie de notación que indica si se poseen o no ciertos rasgos definitorios.

De acuerdo con la gramática generativa, las entradas léxicas corresponden en rigor a matrices de rasgos sintácticos, semánticos y fonológicos que pueden asociarse a distintas palabras en distintas lenguas. En consecuencia, dichas matrices de rasgos han de existir con anterioridad a la adquisición de los términos que las nombran, siendo así que el lexicón estaría conformado por conceptos y no por términos; conceptos tales que existirían con anterioridad a su asociación con cualquier palabra.

b. Componente categorial:

Consiste en un conjunto de reglas que permiten la reescritura de oraciones o conjuntos de oraciones, de forma tal que se generen derivaciones, dichas reglas se conocen como reglas de estructuración de frase y pertenecen a un tipo de gramática llamada estructura de frase gramatical.

Para Chomsky el objetivo del análisis lingüístico no es describir sino separar las secuencias gramaticales que son oraciones de una lengua, de las secuencias agramaticales que no son oraciones de una lengua. A esta definición se pueden remitir, de manera coherente, los conceptos de gramática y de agramaticalidad:

1. La gramática de una lengua es el dispositivo capaz de generar todas las secuencias gramaticales y ninguna de las agramaticales.

2. La oración gramatical es aquella que tiene que ser aceptable para un hablante nativo y generada de acuerdo con las reglas de la gramática.

Lo que Chomsky intenta presentar es una fundamentación del análisis en constituyentes inmediatos. Usualmente, la descripción lingüística al nivel sintáctico es formulada en 
términos de análisis de constituyentes (parsing). Para Chomsky una oración se va a reescribir como una FN + FV.

Reglas de escritura de frase:
a) $\mathrm{O} \rightarrow \mathrm{FN}+\mathrm{FV}$
b) $\mathrm{FN} \rightarrow \mathrm{Art}+\mathrm{N}$
c) $\mathrm{FV} \rightarrow \mathrm{V}+\mathrm{FN}$

En (43) se tiene una estructura mediante reglas para formular una oración ahora bien si se llenan esas reglas con ítems léxicos como los de (44) podríamos generar una oración sintáctica gramatical como la de (45a).
d) Art $\rightarrow$ la
e) $\mathrm{N} \rightarrow$ mujer, pelota
f) V $\rightarrow$ golpeó

a. La mujer golpeo la pelota.

La oración de (45) representa una oración simple. Para generar una oración del tipo subordinada como el hombre que viene tiene un árbol se deben seguir ciertas reglas para su formación. Una transformación generalizada toma dos oraciones como input e incrusta una dentro de la otra como una clausula relativa.

De una forma simplificada la regla se puede escribir como en (46).
Descripción estructural
S1: $\quad \mathrm{X}-\mathrm{FN}-\mathrm{Y}$
$\mathrm{S} 2: \mathrm{W}-\mathrm{FN}-\mathrm{Z}-\mathrm{P}-\mathrm{FN}$
123
$\begin{array}{lllll}4 & 5 & 6 & 7 & 8\end{array}$ 


\section{Condición $2=5$}

Cambio estructural $\quad 1-2+$ quien / que / el cual $+4+6+7+8-3$

Input: El hombre viene. El hombre tiene un árbol.

Output: El hombre que viene tiene un árbol.

Con respecto a la formación de estructuras como las de (46), la "transformación generalizada" de las estructuras sintácticas corresponden al análisis de la FN: las condiciones de identidad se refieren a FN completas y la cláusula relativa se adjunta a la FN de la cláusula principal. Una de las principales innovaciones en Aspectos (Chomsky 1965): Todas las oraciones que se generan están en la estructura profunda. Entonces, la cláusula relativa comienza como una cláusula incrustada en una FN completa y forma una nueva FN.

a.

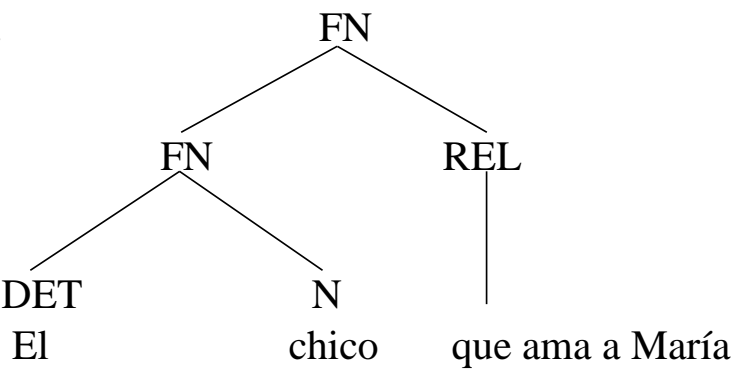

Si consideramos estructuras como las de (48) podemos observar que el análisis propuesto por Chomsky nos permite decir que el relativo que funciona como pronombre, es decir, si tenemos dos elementos (FFNN) que son idénticos podemos reducirlo a uno mediante el uso de un relativo.
a. El chico que viene es vecino mío.
b. El chico que ves es vecino mío 
En (48) el sintagma nominal el chico, que precede a las cláusulas relativas, es su antecedente; son construcciones relativas las secuencias que se componen de una cláusula relativa y su antecedente. La cláusula relativa define una propiedad o calidad que se atribuye al antecedente; éste, a su vez, cumple una función gramatical en la cláusula relativa como ya se ha hecho mención. Por ejemplo, el antecedente el chico se interpreta como sujeto de la cláusula en (48a) y como objeto directo en (48b), de acuerdo con esta descripción que debe estar en la primera posición denominada COMP (49).

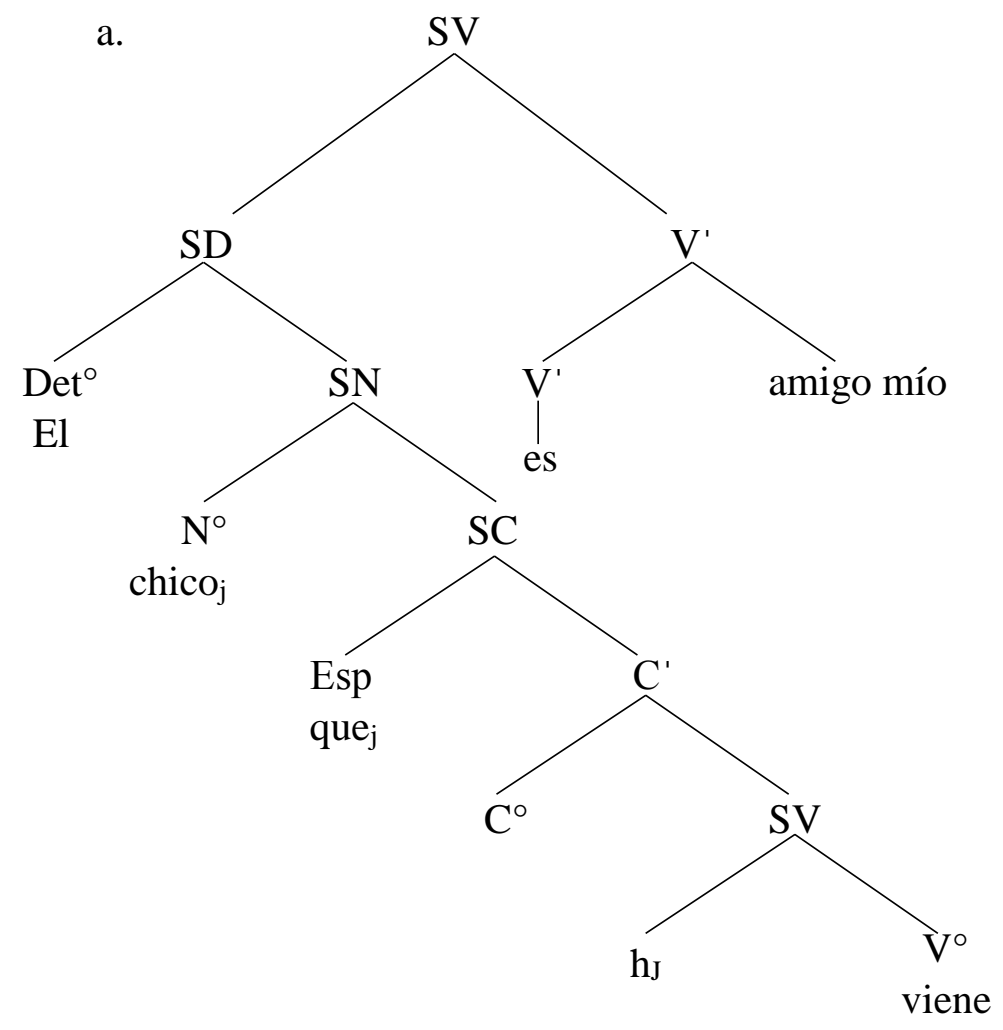

Por lo que no habría problema en analizar las construcciones de (50) donde interviene un determinante.
a. Unos libros con los que se entretuvieron.
b. El cuchillo con el que lo mataron. 


\section{c. Una casa en la que vivía.}

Este análisis nos hace pensar que no hay problema alguno en decir que el elemento que antecede a que es un artículo determinado por la presencia de la cabeza externa y que el núcleo de este es que al ser un pronombre por lo que al analizar tendríamos las oraciones de
a. [ANT [unos libros $\left.{ }_{\mathrm{x}}\right]$ CR [con DET $\left[\operatorname{los} \mathrm{N}_{\mathrm{N}}\left[\mathrm{que}_{\mathrm{x}}\right]\right] \mathrm{sv}\left[\mathrm{suj}\left[\right.\right.$ Pro] se entretuvo $\left.\left.\left.\mathrm{h}_{\mathrm{x}}\right]\right]\right]$

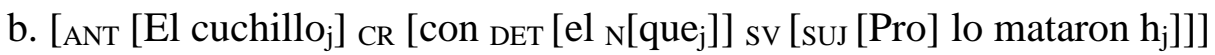

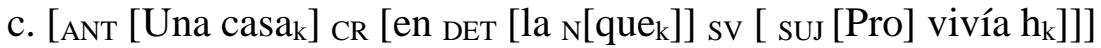

Ahora veamos una oración de las anteriores en un árbol sintáctico donde se puede apreciar la relación de los constituyentes.

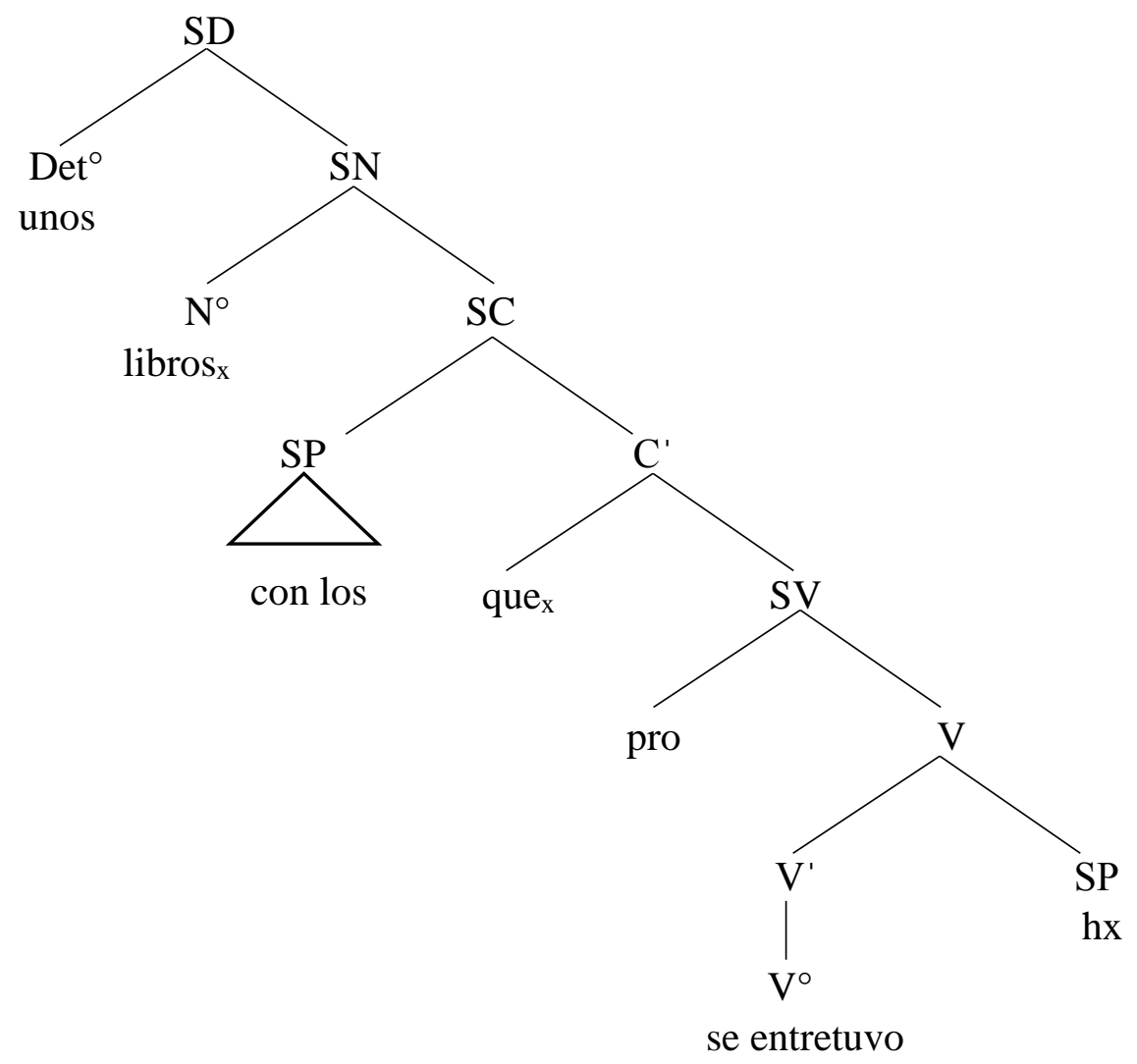


Sin embargo, este análisis no es sostenible ya que como se ha presentado en el apartado 1.1.2.3 que no es un pronombre sino un complementante el cual se genera en la posición $\mathrm{C}^{\circ}$ del SC y no puede tener la misma naturaleza de otros pronombres relativos los cuales sí pueden tener la misma identidad y por lo tanto deben estar coindizados (antecedente, relativo y huella de la posición de origen), además los pronombres relativos se alojan en el especificador del SC.

\subsubsection{Que complementante y movimiento a Espec SC}

En este análisis se postula la presencia de dos cabezas, una externa a la cláusula relativa y otra interna, que se elimina o se reduce, bajo identidad con la cabeza externa. (Lees 1961; Chomsky 1965; Platero 1973; Hale y Platero 1974; entre otros)

a. El libro [el cual $/$ / que/ 0 tú compraste $\mathrm{t}_{\mathrm{i}}$ ]

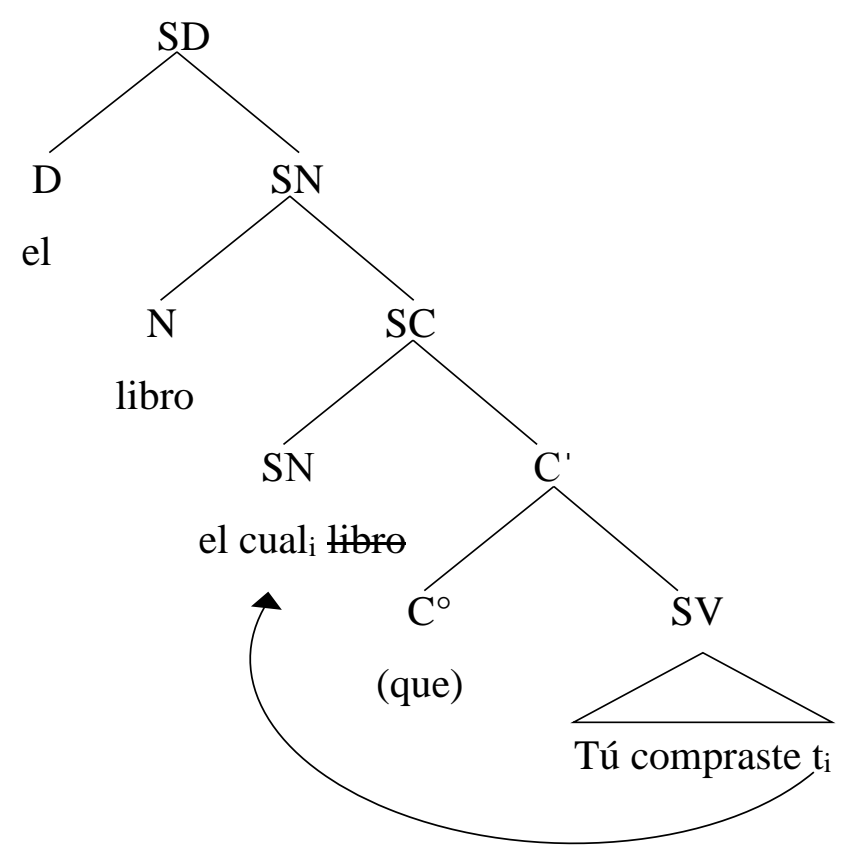


En este análisis la cláusula relativa está unida a la cabeza externa. Al mismo tiempo, también hay una representación de la cabeza externa dentro de la cláusula relativa y es considerada como la cabeza interna como se muestra en la estructura arbórea de (52). La cabeza interna es generada como el complemento del operador relativo (que, quien, el cual, etc) en una posición argumental, toda la FD se mueve a Spec donde se alojan los operadores relativos. Posteriormente, la FN interna se elimina bajo identidad con la cabeza externa, es decir, ambas deben interpretarse. Sin embargo, fonológicamente solo aparecerá la que está en la posición más alta. Es importante destacar que la cabeza externa y la cabeza interna no son parte de una cadena de movimiento.

\subsubsection{Que complementante $\mathrm{C}^{\circ}$ análisis de Brame}

En este análisis se asume la presencia de una sola cabeza la cual es interna a la cláusula relativa, que se eleva al frente de la misma. (Michael Brame 1967; Schachter 1973; Vergnaud 1974; Kayne 1994; Bianchi 1999; De Vries 2002).

Lo interesante de este análisis es que, dado que. la FN que funciona como la cabeza de la cláusula relativa se origina dentro de la misma y es posible interpretarla en una posición interna como se ejemplifica en (53).

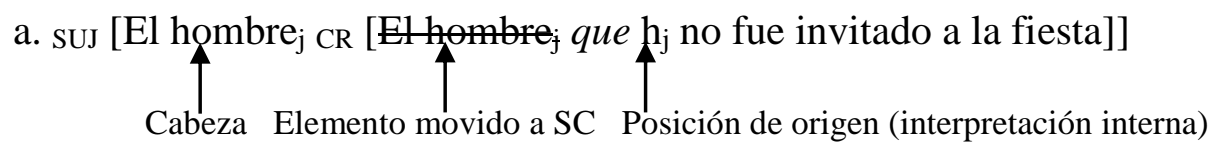

Cabe mencionar que en este análisis que no es considerado un pronombre relativo sino un complementante que solo cumple la función de nexo subordinador de una clausula relativa el cual se origina en la posición nuclear $\mathrm{C}^{\circ}$ del SC. 
a. El librok el librek que tú compraste $\mathrm{t}_{\mathrm{k}}$.

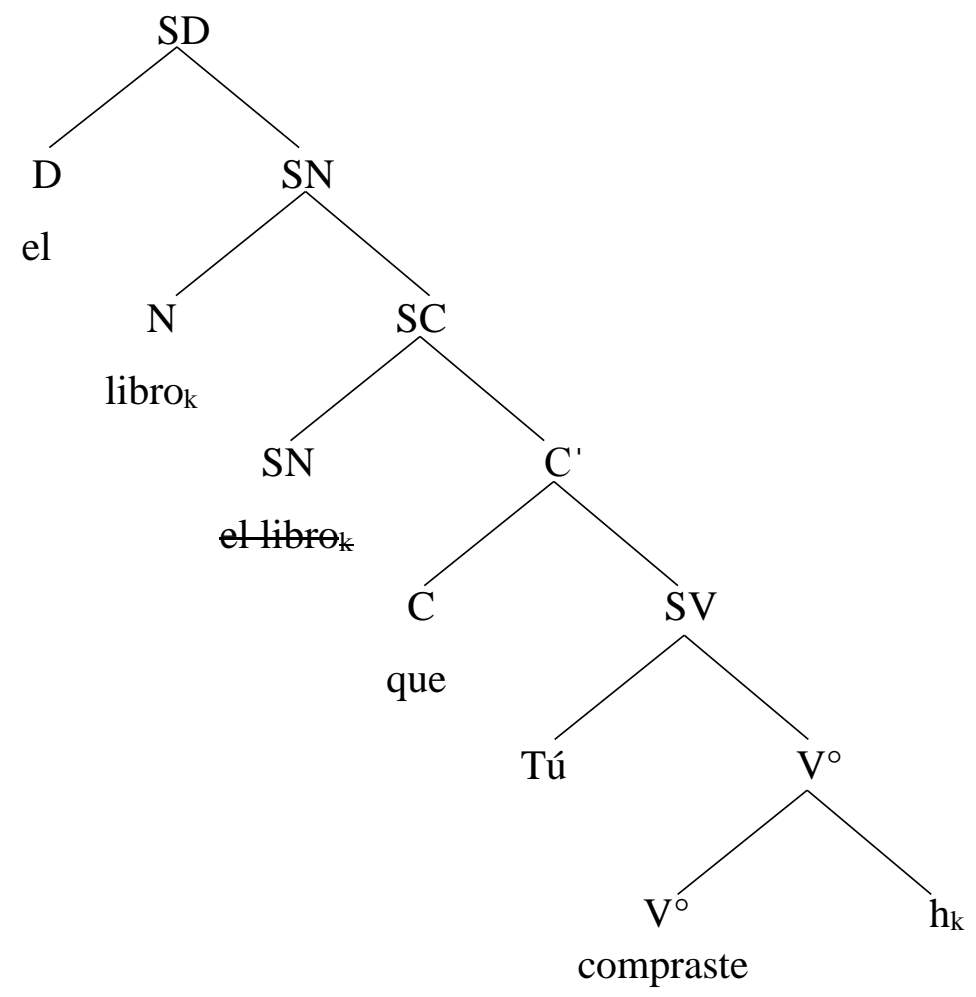

La interpretación de la estructura arbórea de (54) muestra que el SN que se ha movido desde su posición base en donde se le asigna caso y papel temático ocupa la posición de especificador en el $\mathrm{SC}^{10}$ y después se aloja formando la cabeza externa de la cláusula relativa, y en su núcleo $\mathrm{C}^{\circ}$ está el complementante que el cual no está coindizado con ningún elemento de la oración al no formar parte de los pronombres relativos como se muestra en las oraciones de (55) donde el elemento movido se interpreta como un relativo el cual tendrá una función sintáctica si el verbo lo requiere.

\footnotetext{
${ }^{10} \mathrm{El} \mathrm{SN}$ que se adjunta a la posición de especificador del SC se borra después de subir por la identidad del elemento que le antecede.
} 
a. Jesús sv [es suj [ANT [el hombre $]_{\text {CR }}$ [a quien $_{\mathrm{x}}$ María ama $\mathrm{h}_{\mathrm{x}}$ ]]]

b. SUJ [ANT [La llave $]_{\mathrm{j}}$ CR [con la cual $_{\mathrm{j}}$ abres la puerta $\left.\mathrm{h}_{\mathrm{j}}\right]$ sv [se ha roto]

Las oraciones de (55) muestran que el elemento interno y el elemento externo se reducen a un pronombre relativo, en (54a) quien es argumento de OD del verbo subordinado, mientras que en (55b) el pronombre relativo el cual funciona como adjunto del verbo subordinado.

a. ANT [el hombre $\mathrm{k}_{\mathrm{CR}}$ [a quien $_{\mathrm{k}} \mathrm{Sv}$ [suj [Juan] dio oD [el premio] or [a quien $\left.\left.\mathrm{k}_{\mathrm{k}}\right]\right]$

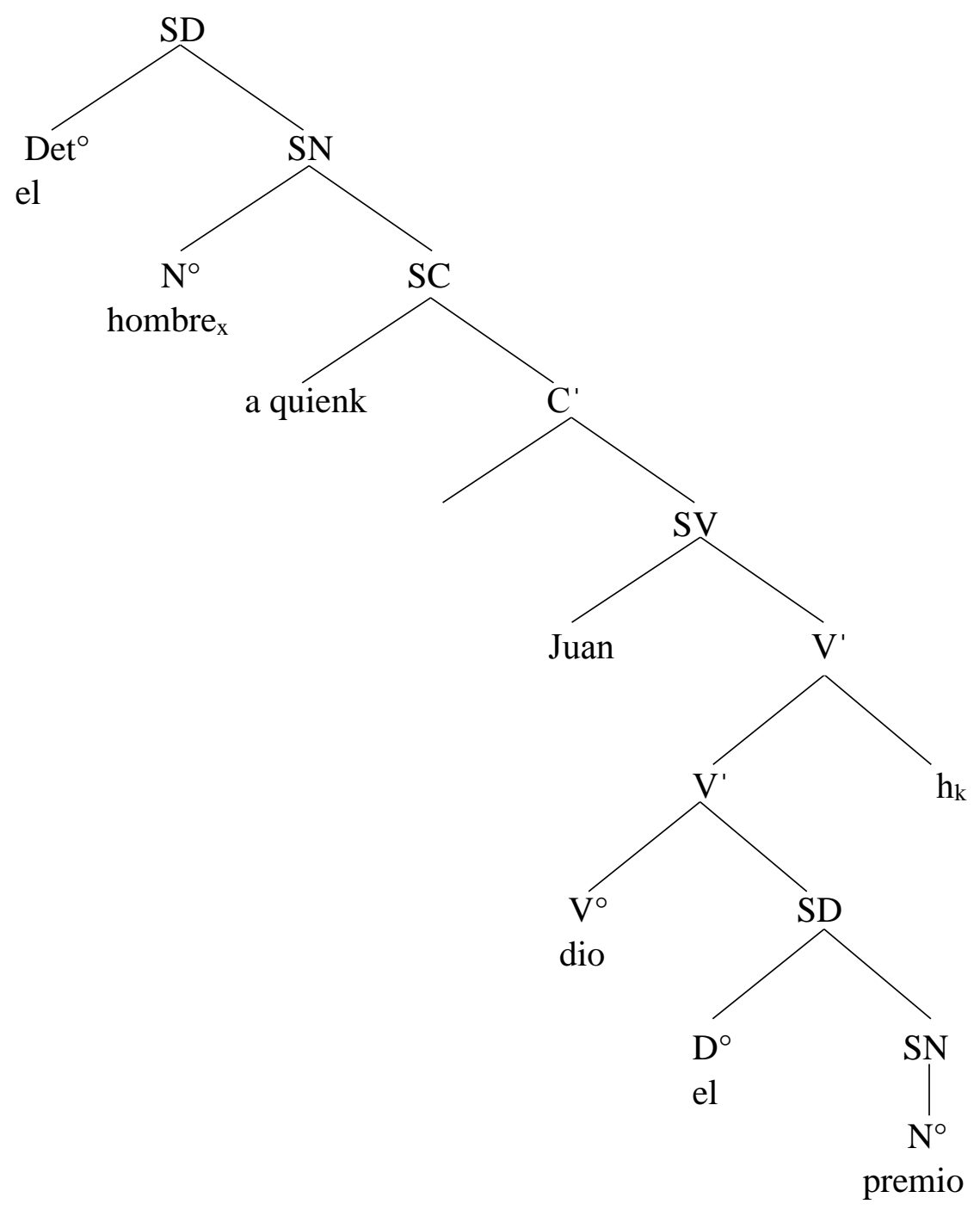


En la interpretación de (56) hay una relación entre la cabeza, el relativo o el elemento movido y la posición base donde se genera el elemento relativizado el cual se ha movido a la posición de especificador del SC interpretándose como un pronombre relativo a causa de la operación "muévase $\alpha$ " lo cual nos permite coindizar los tres elementos en una cadena argumental.

Considérense las oraciones que aparecen en (57)
a. El cuchillo con el que tú cortaste el pan.
b. Unos libros con los que se entretuvieron.
c. Una casa en la que vivía.

En las oraciones de (58) interviene un elemento entre la preposición y el complementante, que al parecer es el artículo definido del elemento interno que se ha movido a la posición de especificador y su núcleo ha sido borrado por la presencia del antecedente.
a. ANT [El cuchillo $\mathrm{x}_{\mathrm{CR}}\left[\right.$ con el euchillo $\mathrm{e}_{\mathrm{x}}$ [que [tú cortaste oD [el pan] $\left.\left.\mathrm{h}_{\mathrm{x}}\right]\right]$
b. ANT [Unos libros $\mathrm{j}$ CR [con los tibros $\mathrm{C}^{\circ}$ [que [Pro se entretuvieron $\left.\left.\left.\mathrm{h}_{\mathrm{j}}\right]\right]\right]$ ]
c. ANT [Una casa $\mathrm{CR}_{\mathrm{C}}$ [en la easa $\mathrm{i}_{\mathrm{i}} \mathrm{C}^{\circ}$ [que [Pro vivía $\left.\left.\left.\left.\mathrm{h}_{\mathrm{i}}\right]\right]\right]\right]$

En (60) se ve claramente el movimiento del SP y la elisión del núcleo de la SN que está en la posición de especificador. En español tenemos el fenómeno sintáctico de pied piping donde la preposición debe moverse junto con la SN porque no puede interpretarse abajo preposition stranding en lenguas como el inglés.

a. El cuchillox $\left[\text { con el euchill } \Theta_{x}\right]_{i}$ que tú cortaste el pan $t_{x}$. 


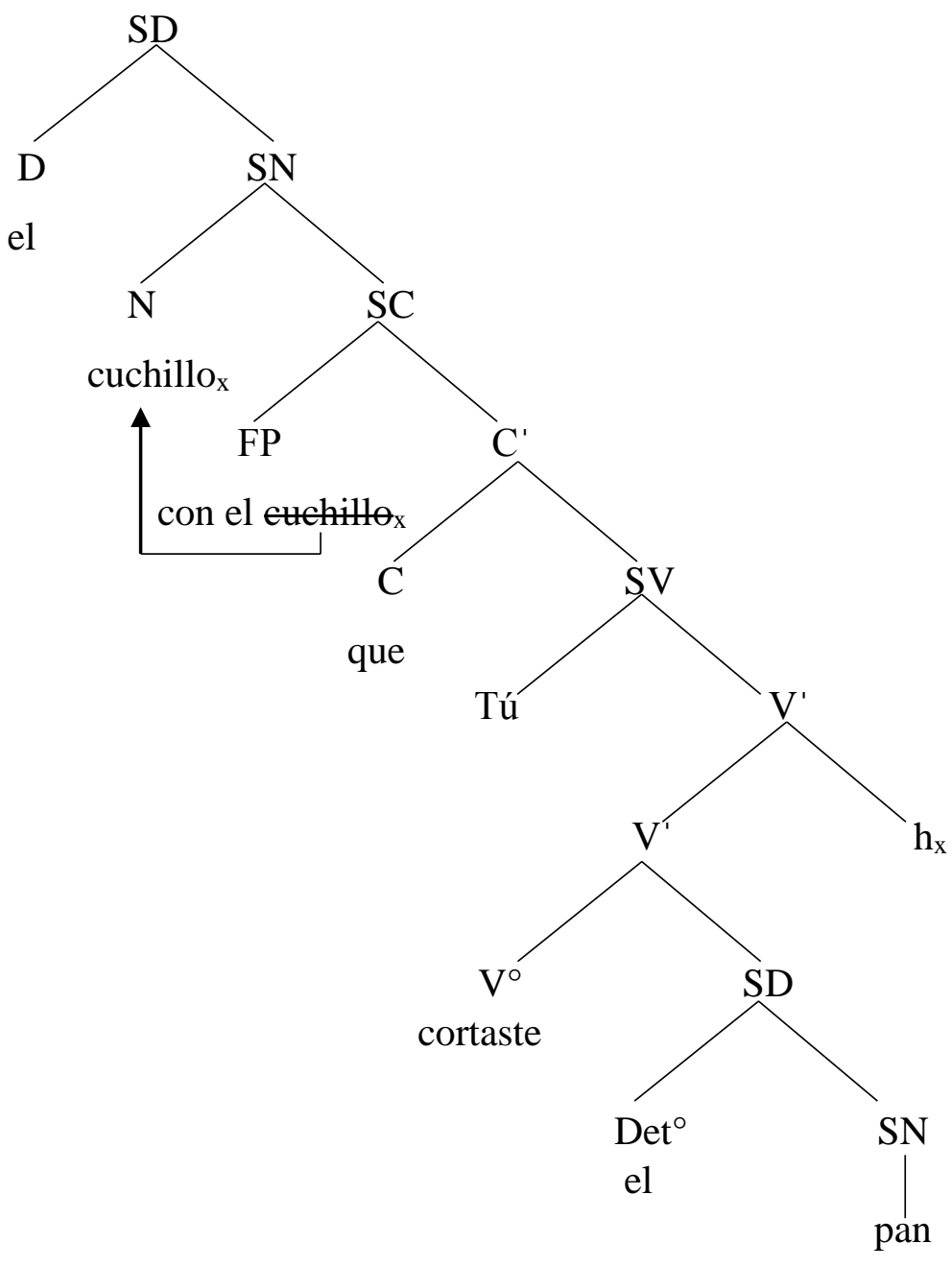

El problema de este análisis es que no explica porque no borra todo el $\mathrm{SN}$ si en análisis anteriores sí lo hace. El análisis que propongo es que el elemento que antecede a que funciona como un pronombre porque hay un rasgo [i] que debe satisfacerse por contexto o por una oración previa (véase capítulo III para más detalle) el cual nos permite eliminar el núcleo del SN como se muestra en el ejemplo (61). 
$(61)$

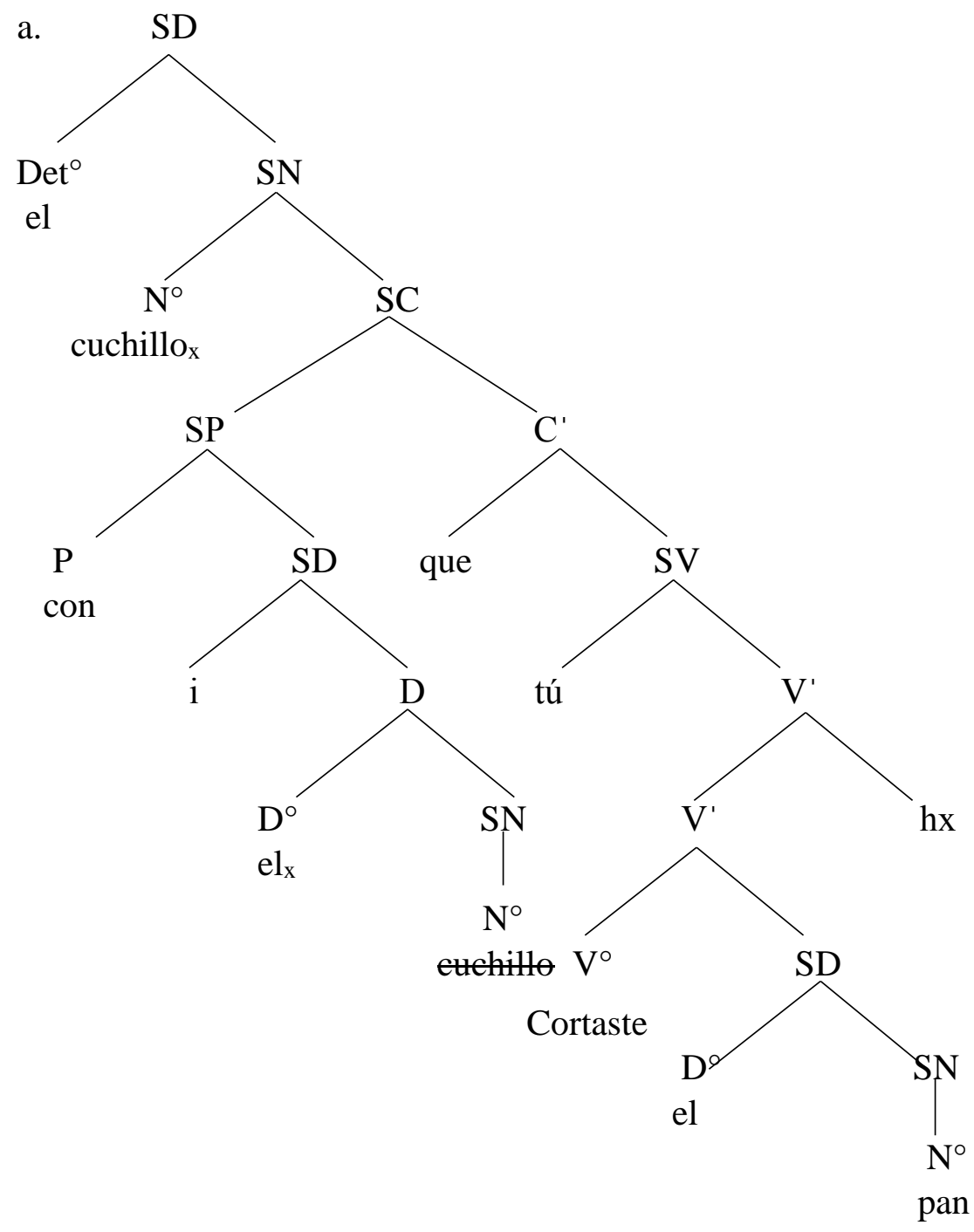

Para los fines de este trabajo, el modelo de Michael Brame (1967) es el que mejor explica el comportamiento de las cláusulas relativas por lo que será este el análisis que tomaré como base para analizar estas construcciones tratando de explicar porque se borra el $\mathrm{N}$ del SD y solo se queda el articulo determinado. 


\section{Capítulo II HEADLESS RELATIVES EN ESPAÑOL}

En esta sección se consideran las relativas especificativas que carecen de antecedente también conocidas como Headless relatives, este tipo de cláusulas de relativo sin un antecedente explícito previo son formadas por la combinación determinante + que han suscitado varios análisis interpretativos a lo largo de la tradición gramatical. Los investigadores han analizado la estructura sintáctica de estas construcciones, originando diversos puntos de vista e interpretaciones que demuestran lo complejo de este tipo de estructuras. Como se vio en el capítulo I, para que una cláusula relativa pueda ser interpretada debe haber una asociación o coindización en algún nivel de representación de la cláusula relativa entre el antecedente, el relativo y la posición básica (huella o copia), es decir, los tres elementos deben tener el mismo índice como se muestra en el esquema de (62). Sin embargo, las oraciones que se muestran en (63) carecen de un antecedente porque no hay ningún elemento previo que nos indique de quién o de qué se habla.

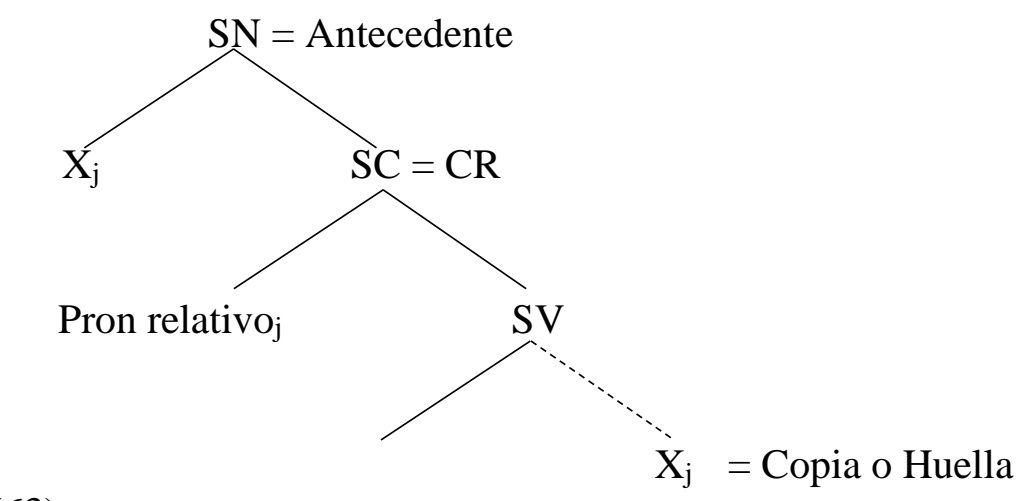

(63)
a. El que llegó también está reprobado.
b. La que traje no funcionó.
c. Ayudamos a los que menos tienen. 


\section{d. Lo que dijo ya lo he olvidado.}

La literatura especializada ha considerado estas estructuras como un solo elemento sintáctico desde el análisis aportado por Bello en su gramática donde argumenta que los elementos el que, lo que, la que, y sus plurales correspondientes deben de tratarse como un solo elemento, es decir, que deben tratarse como pronombres relativos complejos o pueden ser tratados como dos elemento independientes ${ }^{11}$. Sin embargo, análisis posteriores como los de Cinque (1978, 1982) y Ojea (1992) plantean otra manera de analizar estas estructuras donde hay un elemento vacío o elidido entre que y el elemento que antecede al elemento vacío que parece ser un determinante.

Las relativas sin antecedente son posibles, según Brucart (1999), porque el español permite la omisión del núcleo de un SN siempre que el determinante aparezca realizado fonéticamente en las cláusulas relativas.

\subsection{Propiedades}

Las headless relatives también son llamadas cláusulas relativas semilibres, libres o independientes.

\footnotetext{
${ }^{11}$ Las construcciones en las cuales el artículo definido se combina con el relativo que se puede hablar de un relativo complejo, perteneciendo los dos a distintas proposiciones; el artículo a la subordinante y el relativo a la subordinada. El artículo está sustantivado y sirve de antecedente al relativo: «Los que no moderan sus pasiones son arrastrados a lamentables precipicios»: los se refiere a los hombres el cual funciona como el antecedente de que y como sujeto del verbo principal son, y se prefiere esta forma a utilizar el pronombre ellos, porque la proposición que sigue simplemente especifica algo de alguien. «Lo que agrada seduce»; lo es antecedente de que y sujeto del verbo seduce: se dice lo y no ello, por causa de la proposición especificativa que sigue. Siempre que las expresiones dichas se componen verdaderamente de dos palabras distintas, el artículo pertenece a una proposición y el relativo a otra. Bello (1847)
} 
Una de sus propiedades es que pueden tener un antecedente como se muestra en las oraciones de (64) o pueden aparecer sin antecedente ${ }^{12}$ como se muestra en (65).

a. El que viene llegando es el presidente.

b. El hombre con el que habla se llama Luis.
a. El que llegó no trajo regalo.
b. Con el que llegó Juan me cae mal.

En las oraciones de (64a-b) se muestra que el antecedente de ambas oraciones puede interpretarse a partir de la misma oración porque aparecen en la oración principal, evidentemente el que de la oración (64a) se trata del presidente mientras que el antecedente de el que de la oración (64b) se trata de Luis. Ahora bien, si nos fijamos en las oraciones de (65a-b) no podemos descifrar quién es el antecedente porque no está expresado o no fue dicho previamente por lo que en un posible análisis sintáctico no podríamos decir de quién o de qué se habla.

La diferencia entre las headless relatives y las relativas tradicionales ${ }^{13}$ es que en las primeras siempre aparece un elemento que parece ser un determinante y que si prescindimos de él la oración sería agramatical véanse las oraciones de (66).

\footnotetext{
${ }^{12} \mathrm{Al}$ hablar del antecedente de las relativas se enfatiza en el encadenamiento de un elemento de orden superior con respecto a otro que lo contiene, lo cual se produce en virtud de la relación anafórica que mantiene un elemento con otro.

${ }^{13}$ Se habla de relativas tradicionales a las construcciones que consiste de un nominal que funge como la cabeza y una cláusula subordinada interpretada como la que modifica atributivamente al nominal y delimita su referencia.

a. El hombre que trabaja en el parque ha fallecido.

b. Juan es el que ha llegado de Paris.

c. El lápiz con el que escribía toda su vida ha permanecido intacto.
} 
(66)
a. El hombre que esté libre de pecado.
b. El que esté libre de pecado
c.*Que esté libre de pecado.

En (66a) se trata de una cláusula relativa tradicional. Al ser que un complementante no debe estar coindizado con ningún elemento dentro de su categoría rectora. En (66b) se puede observar que es una headless relative, es decir no hay un antecedente por lo que no sabemos de quién se habla, mientras que en (66c) si prescindimos de lo que parece ser el determinante resultaría ser una oración agramatical por lo que es obligatorio que aparezca ya que el complementante que carece de rasgos léxicos y flexivos impidiéndole que encabece oraciones como lo haría el pronombre relativo quien.

Lo que nos lleva a concluir que una de las propiedades más importantes de las headless relatives es que siempre debe aparecer un elemento que anteceda al complementante que del español y siguiendo los trabajos sobre el análisis de éste tipo de cláusulas relativas se puede decir que se trata de un determinante.

Este tipo de cláusulas relativas se han abordado de dos maneras importantes. La primera, el elemento que debe considerarse como un pronombre relativo y por lo tanto debe tener las mismas propiedades que los otros pronombres relativos como quien, cual, etc. Por consiguiente, en este análisis deben considerarse los trabajos de Quine (1960), Montague (1970), Partee (1975), Chomsky (1973, 1977), Jackendoff (1977) entre otros, el análisis propuesto es The Matching Analysis donde la cabeza se origina fuera de la cláusula relativa (SC). La cláusula relativa involucra un movimiento de un operador relativo que debe alojarse en el especificador del sintagma complementante y que se mueve desde la posición de origen. Finalmente, la cláusula relativa se adjunta a la frase nominal que ejerce como la cabeza de la 
cláusula relativa y ambas se combinan semánticamente como se puede apreciar en la estructura arbórea de la oración de (67).

a. sD $\left[\mathrm{El}\right.$ libro $_{\mathrm{x}} \mathrm{SC}\left[\right.$ que $_{\mathrm{x}}\left[\mathrm{Juan}\right.$ leyó $\left.\left.\mathrm{h}_{\mathrm{x}}\right]\right]$

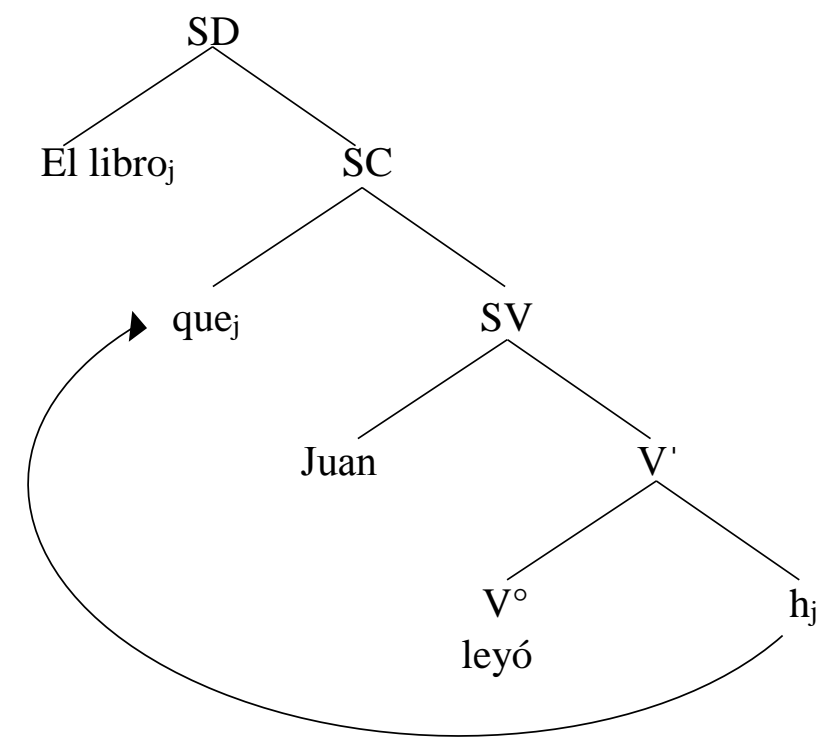

La segunda, el elemento que debe tratarse como un complementante, no como un pronombre relativo y el elemento que le antecede es el elemento relativizado. Lo que significa que contiene un operador vacío o elidido. Sin embargo, el análisis que sigo ${ }^{14}$ es similar al que han propuesto algunos autores como Cinque, Ojea y Brucart.

Las aportaciones sobre el análisis de las headless relatives nos permite tener varias estructuras posibles, estas opciones son representadas en (68)
a. SD $[$ D el $\varnothing]$ i $\left[\right.$ que.... $\left.\mathrm{h}_{\mathrm{i}} \ldots\right]$
b. SD [D el hombre $]_{i}\left[q u e . . . h_{i} \ldots\right]$

\footnotetext{
${ }^{14}$ A diferencia de los otros análisis propuestos, he considerado al elemento que antecede al complementante que del español como un pronombre y no como un determinante como lo han abordado en sus aportaciones otros lingüistas.
} 


$$
\begin{aligned}
& \text { c. } \mathrm{sD}\left[\mathrm{el} \mathrm{que}_{\mathrm{i}} \ldots \mathrm{h}_{\mathrm{i}} \ldots\right] \\
& \text { d. SD [el Proi que... } h_{i} \ldots \text { ] } \\
& \text { e. } \operatorname{SD}[D \text { el] }]_{i}\left[q u e . . . h_{i} \ldots\right]
\end{aligned}
$$

Las estructuras de (68a-b), en efecto, son indistinguibles al no saber porque se elide o se genera un $\varnothing$; la elección de uno sobre el otro dependería del marco teórico asumido en el análisis. En este tipo de análisis aparece un operador vacío o un elemento elidido, como en los análisis tradicionales de las cláusulas relativas. En (68a) el vacío se genera desde la posición base, es decir, se origina in situ, mientras que en (68b) se elimina (o no se enuncia). En (68c) es un análisis más tradicional tomando en cuenta que el relativo tiene la propiedad de pronombre por lo que hay tres coindizaciones y una cadena argumental, es decir, hay un movimiento desde la posición de origen hasta la posición del especificador del SC que posteriormente se enlaza con la cabeza de la cláusula relativa. La estructura propuesta en (68d) muestra que hay un Pro que funciona como el núcleo del determinante, mientras que en (68c) se ejemplifica un análisis posterior a los que ya se han mencionado, en este el relativizador que es considerado un complementante y el elemento que le antecede es un determinante con función de pronombre ${ }^{15}$.

Para más claridad en los tipos de análisis véanse las estructuras arbóreas de (69) las cuales muestran los diferentes análisis ya mencionados.
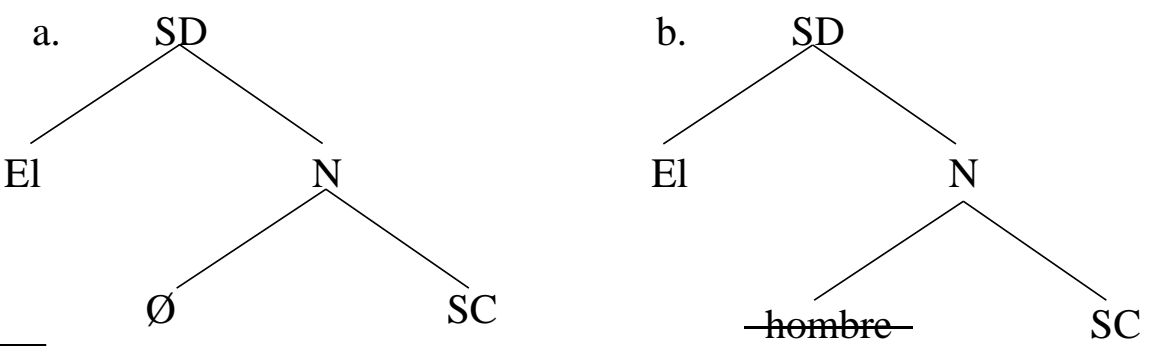

\footnotetext{
${ }^{15}$ En español el determinante es similar a los pronombres personales. Para más información léase con detalle el trabajo de Rodríguez Gutiérrez, Edita (2008) Rasgos Categoriales de los Determinantes.
} 

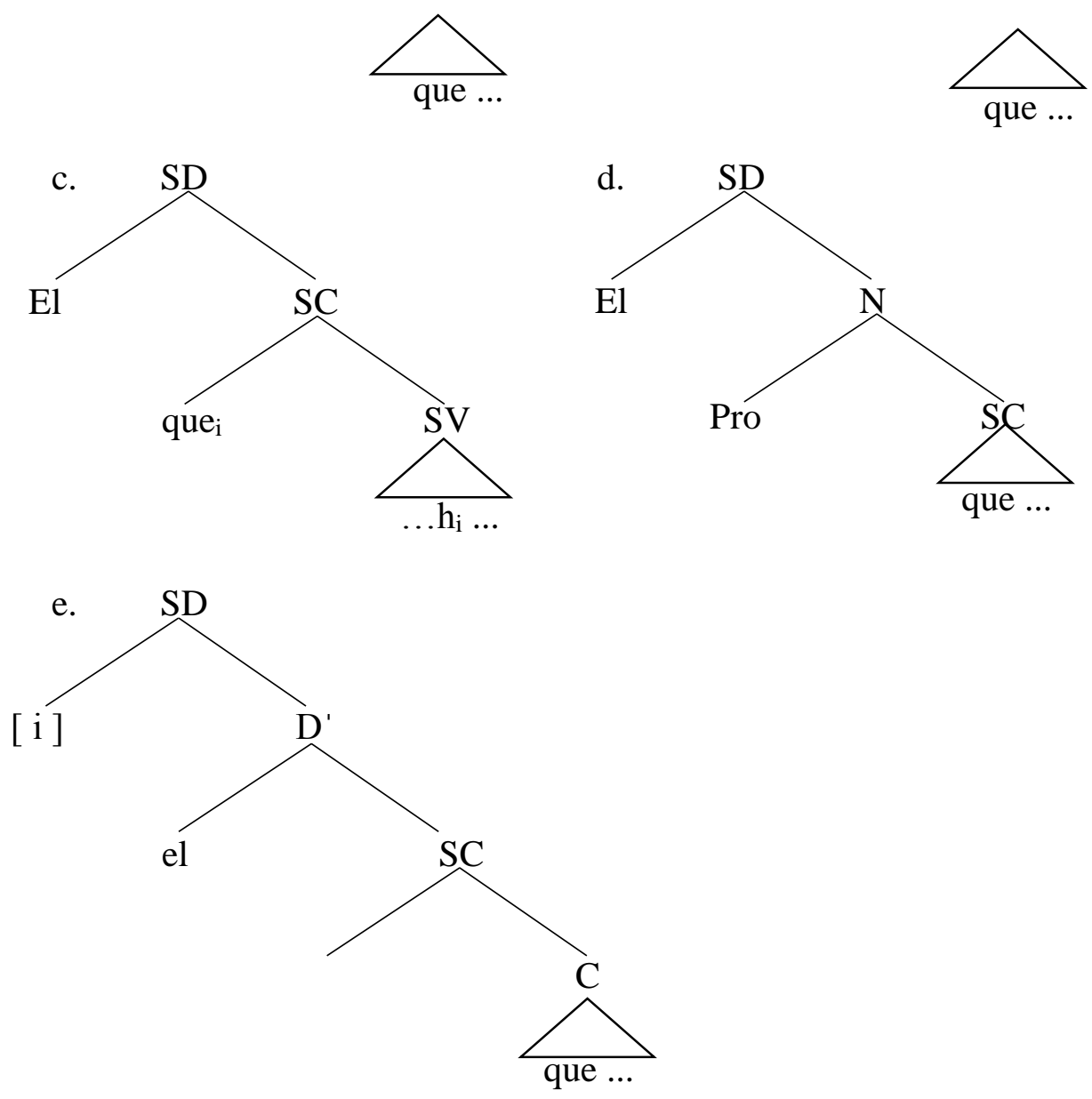

\subsubsection{Sin antecedente explícito}

Una de las funciones características de las cláusulas relativas es la de actuar como modificadores dentro de un sintagma nominal, la gramática tradicional las ha denominado subordinadas adjetivas. Se trata de una caracterización funcional que parte de la idea de que cualquier complemento nominal tiene valor adjetival. Pero esta etiqueta no se aviene con todos los usos de las relativas, ya que algunas no necesitan un antecedente nominal explicito para poder desempeñar directamente una función en la oración matriz, Plan (1980). Esto es 
lo que ocurre con las llamadas Headless relatives ${ }^{16}$ como se ejemplifica a continuación en (70).

(70)

a. CR [ sc [Quien] sv [bien te quiere]] sv [no te hace llorar].

b. $\mathrm{CR}$ [sc [El que me gusta] sv [ya no está].

La cláusula relativa de (70a) carece de un antecedente en la oración matriz o principal, a pesar de esto desempeña una función gramatical que es ser el sujeto, lo mismo ocurre en la oración de (70b) donde no hay un antecedente por lo que no sabemos de quién se habla.

Los relativos que incorporan los rasgos léxicos que determinan el tipo de entidad representado por la subordinada tienen la posibilidad de encabezar cláusulas relativas, tal es el caso del pronombre relativo quien que denota personas como en la oración (71a). Lo mismo ocurre con el complementante $q u e^{17}$ el cual al carecer de rasgos léxicos y flexivos no puede encabezar cláusulas relativas véase ejemplo (71b) por lo que sintácticamente debe aparecer un elemento que satisfice esos rasgos gramaticales, muchos autores han mencionado que se trata de un determinante el cual ayuda a coocurrir al complementante y puede encabezar dichas construcciones como se ejemplifica en (71c).
a. El hombre a quien $_{\mathrm{x}}$ Juan gritó $\mathrm{h}_{\mathrm{x}}$ era su padre.
b. *Que tiene hambre de poder se envenena solo.
c. El que tiene hambre de poder se envenena solo.

\footnotetext{
${ }^{16}$ Este tipo de relativas incorporan semánticamente su antecedente, pero no lo expresan de manera sintáctica.

${ }^{17}$ Como ya se mencionó anteriormente que era tratado como un pronombre relativo, sin embargo, en el apartado 1.1.2.3 se dieron las pruebas para descartar esta idea, tratándolo como un complementante, es decir, como un nexo de subordinación.
} 
En las cláusulas relativas prototípicas siempre está presente el antecedente del relativo que además presenta una coindización entre el mismo relativo, su antecedente y su posición de origen, en las headlees relatives no ocurre lo mismo, lo que se busca analizar no es el antecedente del complementante sino el antecedente y el papel gramatical que desempeña el determinante en dichas construcciones.
a. El que compró Luis tiene muchas fallas.
b. $L a$ que vende Juan es de mejor calidad.
c. Lo que me gusta es la sintaxis.
d. Los que llegaron tarde van a reprobar.
e. Las que reprobaron el examen tendrán una segunda oportunidad.

Además de las construcciones de (72) tenemos otras donde se involucra el uso de los demostrativos ese, esa, este, esta, aquel y aquella como se ejemplifica a continuación en (73).
a. Ese que tengo no me gusta.
b. Esa que perdí era mi favorita.
c. Este que me trajo mi mamá me ha gustado bastante.
d. Aquel que llegó está reprobado.

En las oraciones de (73) los demostrativos funcionan como los deícticos ${ }^{18}$, partiendo de esta

\footnotetext{
${ }^{18}$ La deixis comprende aquellas formas lingüísticas que designan una relación entre el lenguaje y el contexto y está ligada directamente con las circunstancias de la enunciación, (Levinson, 1989).
} 
idea su antecedente debe estar en un contexto extralingüístico que nos permite identificar su referente, lo mismo que puede ocurrir con los determinantes.

Si bien las oraciones de (72) y (73) muestran el uso de los determinantes y los demostrativos cuyo referente está en un contexto extralingüístico, hay oraciones que también involucran esta secuencia, pero el antecedente sí está presente en el contexto oracional esto se ejemplifica en las oraciones de (74) donde está presente la flexión (ser).
a. El que me llamó fue el presidente.
b. La que llegó es María.
c. El premio fue lo que más me gustó.
d. Ese que llegó es el mensajero.

En las secuencias de (74) es evidente que el referente del determinante está presente en la oración principal, es decir, hay una correferencia entre el antecedente y el determinante de la Headless relative véase el ejemplo de (75).

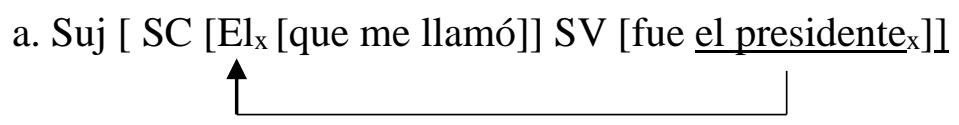

No solo con la flexión (es) aparece el antecedente en la misma oración sino también cuando se involucra una preposición entre la secuencia Det + que como se ejemplifica en (76).
a. El cuchillo con el que corta el pan.
b. La golpiza con la que lo dejaron casi muerto.
c. El periódico para el que trabaja. 
d. Los logros de los que está orgulloso.

Más adelante en el análisis se mostrará que el determinante funciona como un pronombre y que su antecedente se recupera por medio de dos posibilidades:

a. Por contexto extralingüístico

b. Por una oración previa.

\subsection{Análisis}

Como se ha hecho hincapié en este capítulo hay varios análisis en torno a este tipo de cláusulas relativas sin antecedente, sin embargo, análisis más actuales como los de Cinque (2003) y Ojea (1992) tienen una visión interesante que nos ayudan a esclarecer un poco este tipo de construcciones.

\subsubsection{Análisis propuesto por Ojea}

Para Ojea (1992) las relativas libres son construcciones que comparten lo esencial de las oraciones relativas básicas, pero no tienen antecedentes léxicos, es decir, no tienen cabezas y están sujetas a una condición de coincidencia que obliga al operador relativo a satisfacer las restricciones de selección tanto de la oración principal como la del verbo de la relativa.

Su trabajo se centra en las headless relatives del inglés y el español y propone un análisis sintáctico de estas construcciones como una categoría mixta fuera del SC y del SD los cuales están conectados a través de un nominalizador $\left(\right.$ switch $\left.^{19}\right)$ como se muestra en (77).

\footnotetext{
${ }^{19}$ Es un recategorizador que permite la transición de una categoría a otra, y que constituye una categoría sintáctica (funcional) en sí misma, esta categoría es denominada por Ojea como Snom.
} 

a. I'm sorry for [what I did].
b. They considered [what they suggest].
c. [What I cooked] was terrible.

Como muestran los ejemplos anteriores de (77) los relativos aparecen en las posiciones del SD y están sujetos a los mismos requisitos estructurales que los SD tradicionales, es decir, tienen la necesidad de aparecer en posiciones en las que aparece un SD como se muestra a continuación en (78)
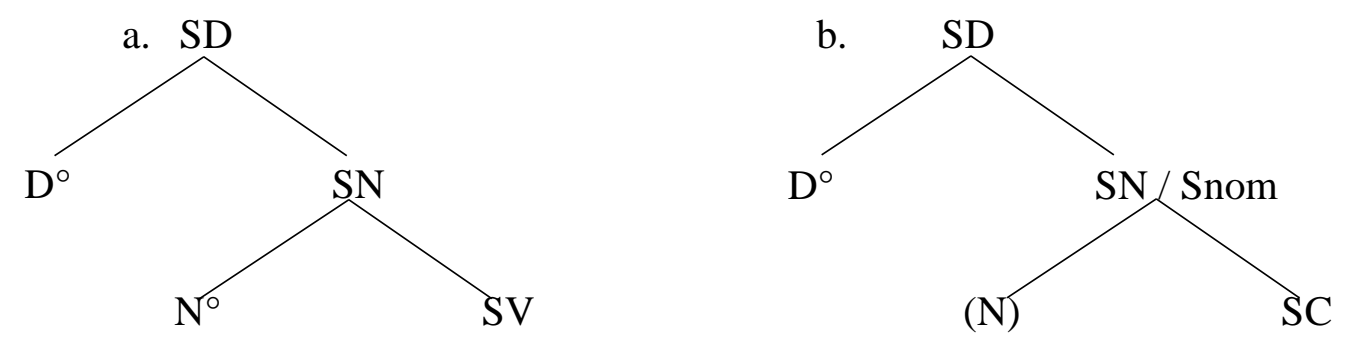

En (78a) se muestra la estructura arbórea de un SD estándar donde hay un determinante y un núcleo nominal, mientras que en (78b) hay un nodo $\operatorname{Snom}^{20}$ el cual nos permite prescindir del núcleo del SD.

Las cláusulas relativas libres son construcciones que comparten lo esencial de las cláusulas relativas estándar, es decir, son modificadores que involucran un operador relativo, pero no encajan en la definición de las cláusulas relativas tradicionales puesto que no modifican a un SN ya que carecen de un antecedente (no tienen cabeza).

Los análisis formales sobre las cláusulas relativas han adoptado dos enfoques diferentes para tratar de explicarlos:

\footnotetext{
${ }^{20}$ Es un nodo donde se encuentra el nominalizador.
} 
a. La frase relativa es un nominal complejo con un antecedente y una cláusula subordinada.

b. La frase relativa es un constituyente de una cláusula con una frase-wh a la que se puede acceder de alguna manera desde afuera.

El análisis que presenta Ojea en su trabajo consta de dos categorías, un SD y un SC conectadas a través de un switch que ella denomina nodo Snom. El complemento de Snom es una cláusula completa con un operador relativo que se traslada al especificador del SC. Sin embargo, las relativas libres implican crucialmente un paso más en la derivación: el elemento wh debe aterrizar en Espec del Snom e ingresar allí en una relación especificadorcabeza para licenciar (y así activar) el nodo Snom (switch). Dado que la cabeza de Snom tiene una función $[\mathrm{N}]$, la clase de frases wh que pueden alojarse ahí se limitará a las nominales; por lo tanto, solo las frase-wh y los SD se producen en este análisis véase la estructura arbórea de (79).

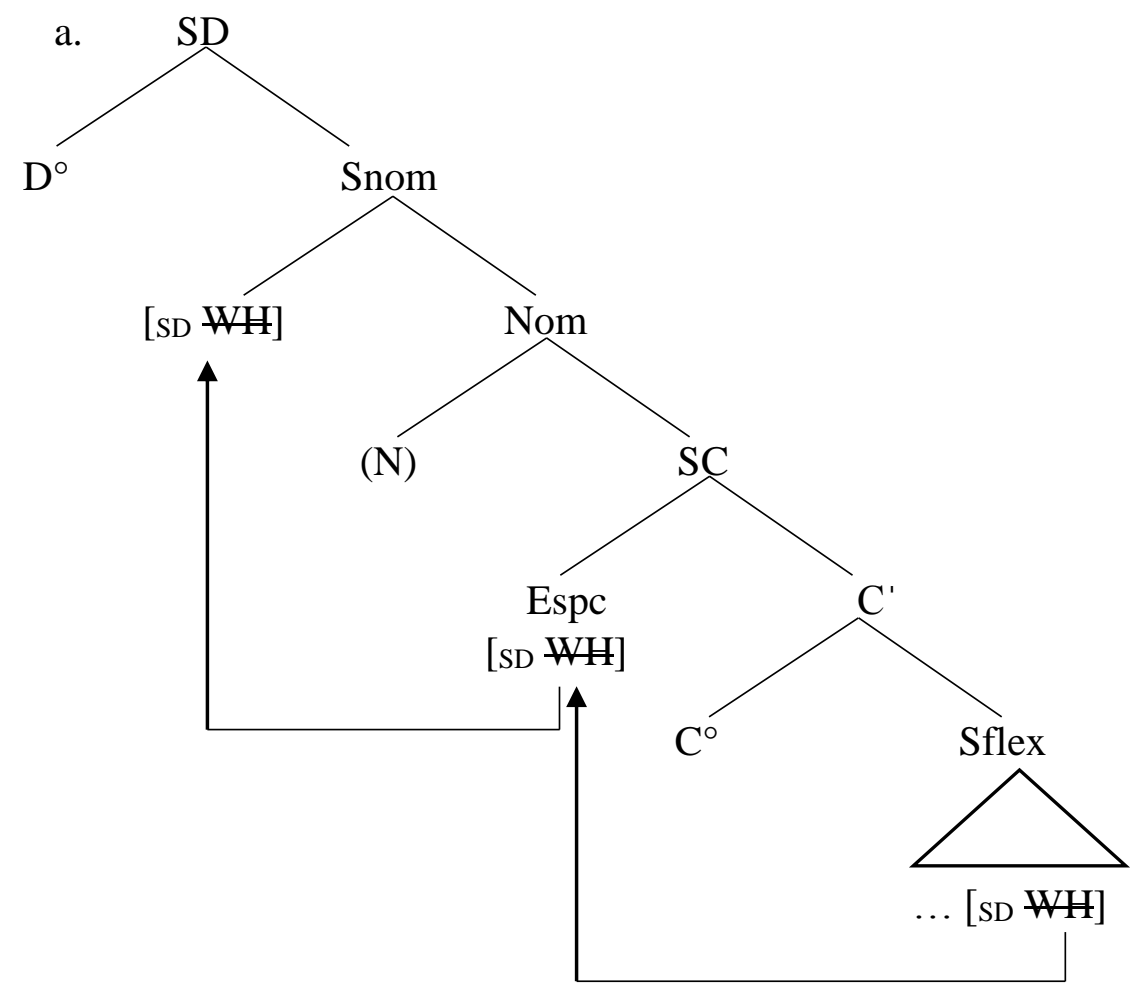


Una de las ventajas del análisis que acabamos de esbozar es que permite un tratamiento unificado de las oraciones relativas y libres. Ambos tipos de oraciones relativas consisten, bajo este punto de vista, en un SC [REL] adjunto a una categoría nominal (un SN léxico o un Snom funcional, respectivamente) complemento de una proyección de un SD funcional.

El proceso de relativización también es el mismo para ambos tipos de relativas: la frasewh se traslada a Espec del SC para verificar la característica [REL] allí, y las relativas libres solo difieren de un movimiento adicional hacia Espec del Snom por razones interpretativas como sucede en español a las cuales denomina relativas semi-libres.

Las headless relatives en español comparten la mayoría de sus propiedades estructurales y semánticas con las relativas libres en inglés y, por lo tanto, pueden abordarse bajo las mismas líneas, es decir, como categorías mixtas que involucran un dominio en el SC, un switch (Snom) y un SD resultante. La cláusula contiene un operador relativo que, como en inglés, es léxico; se mueve a al Espc del SC de la manera habitual, y luego al Espec del Snom, donde tiene que identificar la característica $[\mathrm{N}]$ de la cabeza.

a. Prefiero [SD Snom [SD [a quien] $]_{\mathrm{x}} \mathrm{SC}$ [a quien $\mathrm{a}_{\mathrm{CR}}$ [ Pro conocí a quien ayer] $_{\mathrm{x}}$

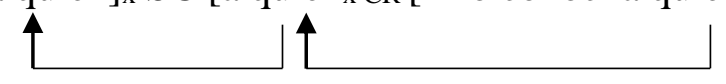

El español permite una construcción, a veces denominada relativas semi-libres cuya interpretación y distribución es equivalente a las relativas libres. Consiste en el artículo

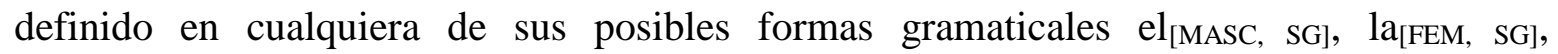
lo[Neutro, SG], los [MASC, PL], las [FEM, PL], seguido de una cláusula introducida por el complementante que. 

a. Prefiero el que trajo Luis.
b. Prefiero la que trajo Luis.
c. Prefiero lo que trajo Luis.

El español tiene un complementante que el cual se proyecta obligatoriamente en el SC donde se aloja el operador relativo [REL]. Las condiciones que obligan al operador relativo a ser una cabeza en español, no se aplican en inglés. En inglés, el operador relativo puede ser opcionalmente cubierto dependiendo de la función sintáctica que desempeña en la cláusula subordinada, mientras que, en español, es la categoría de este operador la que fuerza la opción $\mathrm{y}$, por lo tanto, siempre debe haber un SD encabezando al complementante para poder alojarse en el SC.

\subsubsection{Análisis propuesto Cinque}

El análisis que propone Cinque $(2003,2008)$ lo ve como un desafío particular para el análisis generalizado de las cláusulas relativas llamado double-headed analysis que trata de mostrar el comportamiento de las headless relatives.

Lo que Cinque $(2003,2008)$ propone en sus trabajos sobre las cláusulas relativas es que los diferentes tipos de estas estructuras están atestiguados en las lenguas del mundo (posnominal con una cabeza externa, pre-nominal con cabeza externa, pueden tener una cabeza interna o puede tener doble cabeza, sin cabeza o libre, los cuales pueden ser derivados de una única estructura llamada double-headed analysis que a través de diferentes 
operaciones sintácticas justificadas de forma independiente (movimiento y eliminación), pueden ser analizadas desde el Matching ${ }^{21}$ y Raising ${ }^{22}$ analysis.

Al seguir este análisis, el SC que contiene el pronombre-wh para incrustarse en una estructura del SD más grande, sugiere específicamente que tal estructura es un SD completo con el SC que contiene a la cláusula relativa la cual se encuentra fusionada en un especificador que modifica una parte de la proyección extendida nominal que constituye la cabeza externa que se une a la cabeza interna como en cualquier otro tipo de cláusula relativa véase la estructura arbórea en (82).

a. El que Juan compró [el carro rojo]

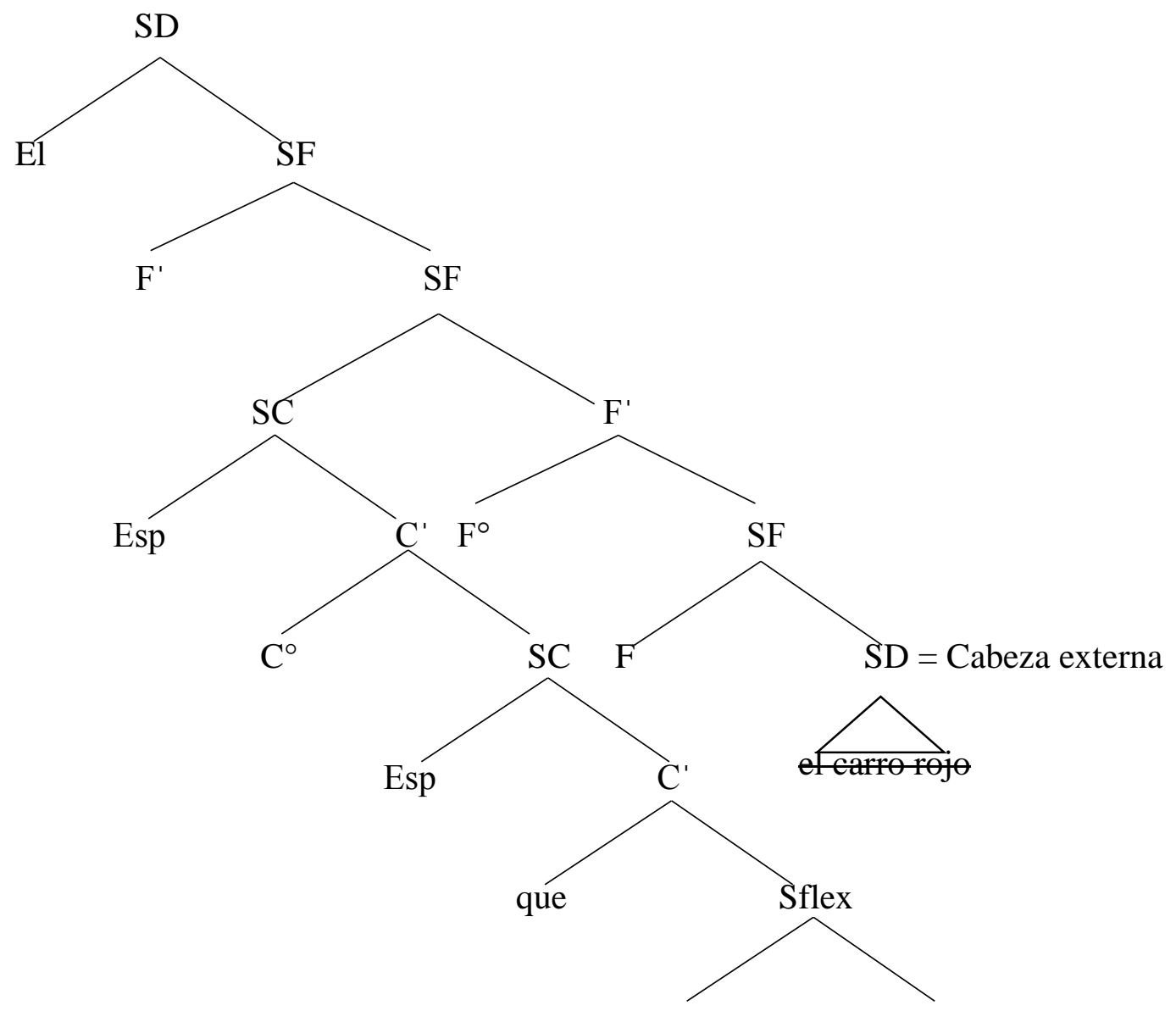

${ }^{21}$ Lees 1961; Chomsky 1965; Platero 1973; Hale and Platero 1974; entre otros.

22 Brame 1967, 1976; Schachter 1973; Vergnaud 1974; entre otros. 
Juan

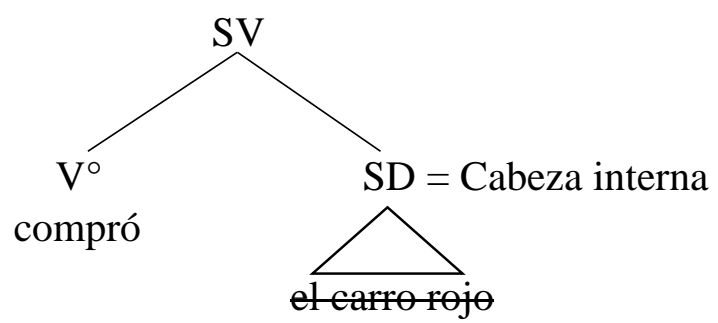

La estructura de (82a) muestra la asimetría que Cinque hace para el análisis de las headeless relatives la cuales tiene dos cabezas que fonéticamente no se pronuncian ya que el SD más alto contiene la información de ambas cabezas.

En the double-headed análisis intervienen los dos movimientos que se hacen en los dos modelos que Cinque utiliza para dar cuenta de las headlees relatives. En su análisis para el inglés el pronombre relativo what es equivalente a el que, la que, lo que, etc, y de acuerdo a lo propuesto por Cinque este relativo se sitúa en el SD como ocurre en el español (83).

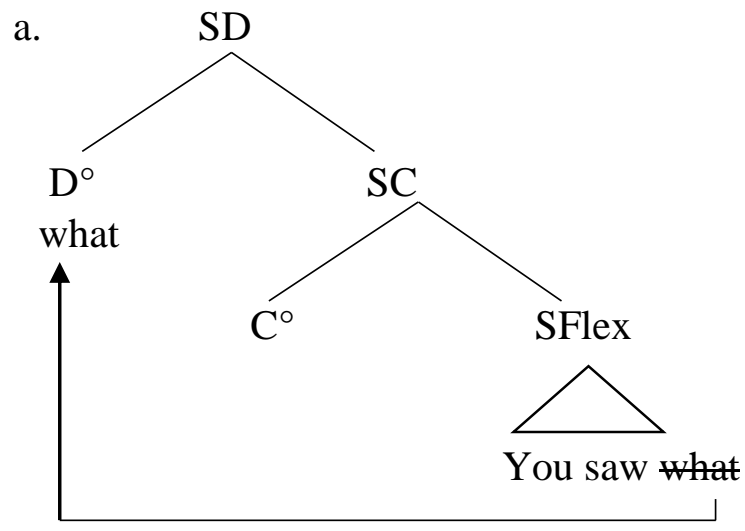




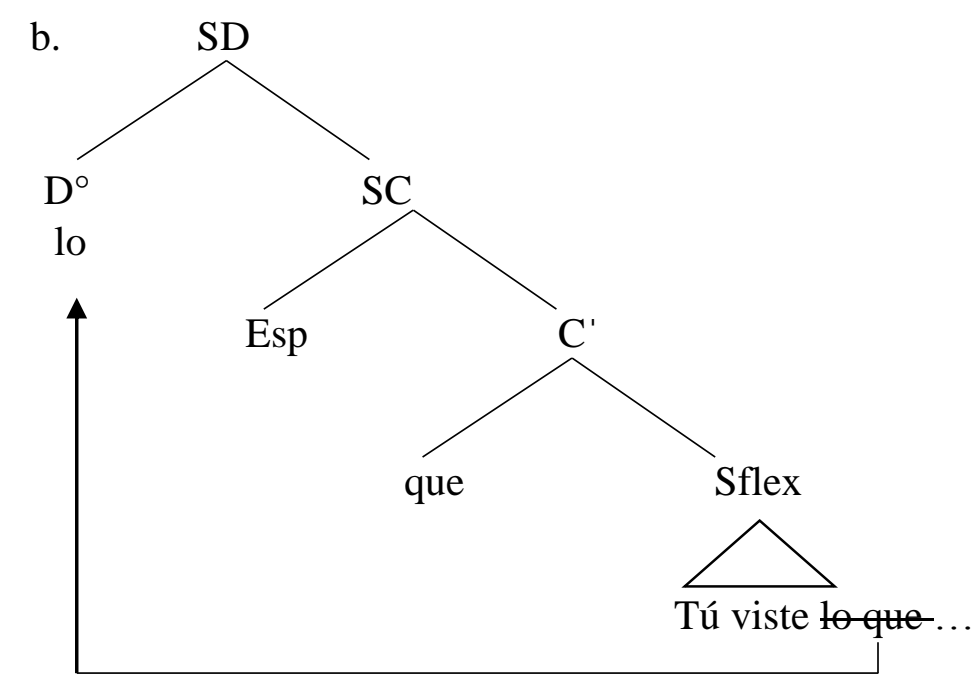

\subsubsection{Análisis Headless relatives}

El análisis que se presenta a continuación se basa en el modelo de Michael Brame (1967) (ver apartado 1.1.3.3) llamado the Raising analysis en el cual se asume la presencia de una sola cabeza la cual es interna a la cláusula relativa, que se eleva al frente de la misma.

Como se ha venido mencionando el que del español no es un pronombre relativo al carecer de rasgos léxicos y flexivos sino un complementante que sirve como nexo para introducir oraciones subordinadas de relativo como se ejemplifica a continuación en (84).

a. Suj [ SD [el hombre SC $_{\text { hombre }}$ que $h_{x}$ trabaja]]

Para las cláusulas relativas como la de (84) el análisis que se ha presentado nos muestra el comportamiento de las cláusulas relativa prototípicas, es decir, aquellas en las que modifican a un nominal, véase la estructura arbórea de (85). 


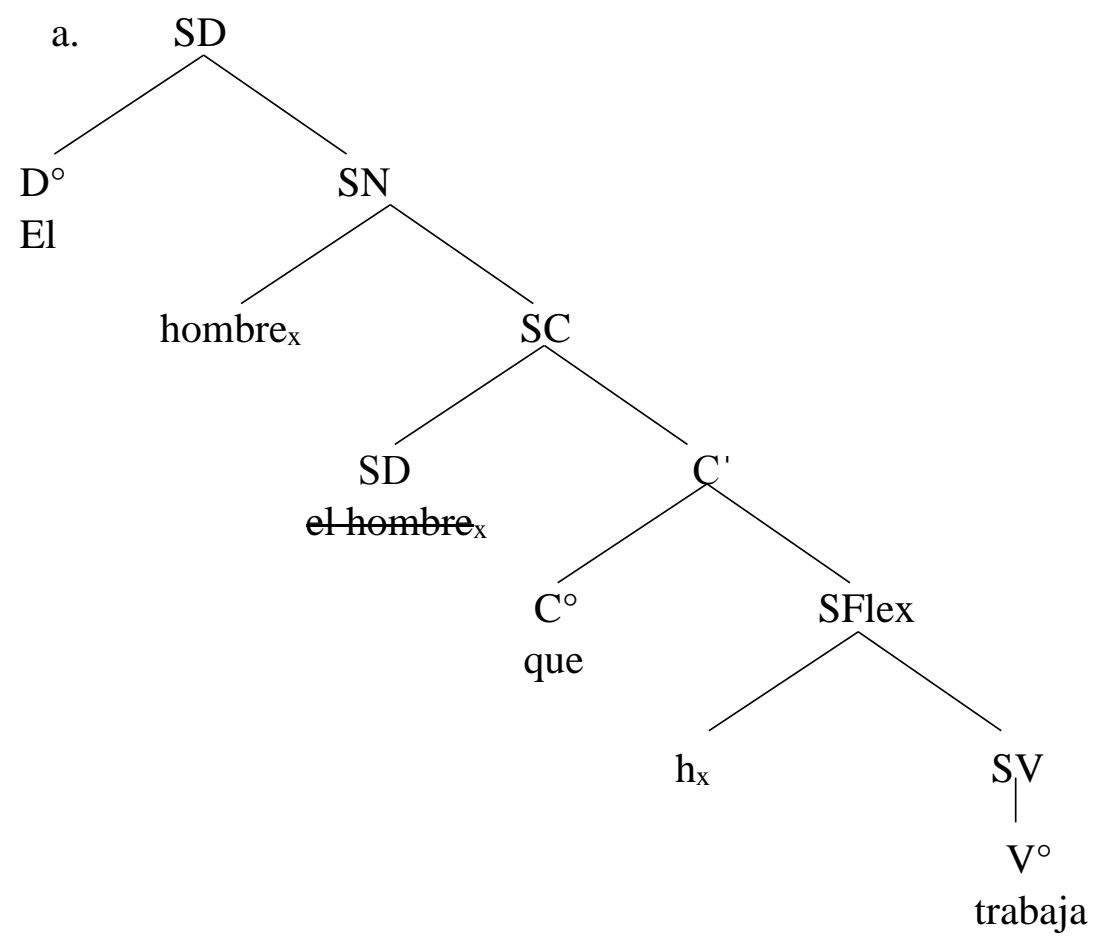

La interpretación de la estructura arbórea de (85) es el análisis propuesto por Brame en el cual explica el comportamiento de los constituyentes de una cláusula relativa prototípica, si bien que no es un pronombre relativo sí cumple la función de ser el nexo subordinante en las cláusulas relativas a diferencia del pronombre quien que sí sale de una posición temática y argumental, mientras que cuando aparece el complementante lo que se mueve es un constituyente de la oración principal que puede estar en función de sujeto, objeto, etc., véanse los ejemplos de (86)

a. SFlex [Suj [Juan] [perdió]] oD [ SD [el libro SC $_{\text {[ el libro }}$ que le regalaron $\left.\left.\mathrm{h}_{\mathrm{x}}\right]\right]$ ].

b. SD [el hombre $\mathrm{k}_{\mathrm{CR}}$ [a quien $\mathrm{kv}$ [suJ [Juan] dio oD [el premio] or [a quien a $\left.\left._{\mathrm{k}}\right]\right]$

En las oraciones de (86) se muestra la asimetría entre el comportamiento de quien el cual sí es un pronombre relativo y el elemento que se mueve en las oraciones donde se encuentra el complementante que está en la posición $\mathrm{C}^{\circ}$ del SC y por lo tanto no presenta movimiento. Ambos elementos están en el SC, pero se alojan en diferentes posiciones de este nodo. 
Ahora bien, tómense en cuenta los ejemplos de (87) donde se involucra un elemento del cual se debe esclarecer su naturaleza (artículo determinado) y por qué está en esa posición o que función cumple en estas estructuras que son el propósito de esta tesis, las llamadas Headless relatives.

Recordemos que una cláusula relativa se define como una estructura subordinada a una oración principal o matriz que modifican generalmente a un sintagma nominal denominado antecedente, sin embargo, como se presentó a lo largo de este capítulo las headlees relatives carecen de antecedente, por lo que nos debemos preguntar si en realidad forman parte de este tipo de estructuras, los ejemplos se presentan en (88).
a. El que lleva las gafas tiene un Ferrari.
b. La que más me gusta tiene novio.
c. Lo que estoy pensando no me hace bien.
d. Los que llegaron tarde han reprobado.
e. Las que compró Luis eran más saludables.

Para entender el comportamiento de este tipo de cláusulas relativas es importante determinar el valor del artículo determinado que aparece en las construcciones de arriba, es decir, es un artículo determinado con un nominal elidido o un elemento vacío como un Pro, si es así qué licencia su aparición en dichas construcciones. En el capítulo tres, sección 3.1.1.2 se presentan los datos para tratar al determinante como un pronombre, en este caso la naturaleza del determinante en estas construcciones es la de un pronombre al tener las mismas funciones deíctico-pronominal, es decir, su referente se encuentra en un mundo posible y esto puede ser representado por el rasgo [i] que se encuentra presente cuando el determinante funciona como un pronombre. 
Por lo que el análisis que da cuenta de este tipo de oraciones se presenta en (89).

a. suJ $\left[\mathrm{sD}\left[\left[\mathrm{i}\left[\mathrm{El}_{\mathrm{x}}\right]\right]\right.\right.$ sc $\left[\mathrm{et}_{\mathrm{x}}\right.$ que sv [ $\mathrm{h}_{\mathrm{x}}$ lleva las gafas $\left.\left.\left.]\right]\right]\right]$ sv [tiene un Ferrari] .

b. suj $\left[\mathrm{sD}\left[\mathrm{i}\left[\mathrm{Lo}_{\mathrm{x}}\right]\right] \mathrm{sc}\left[\mathrm{H}_{\mathrm{x}}\right.\right.$ que sv [Pro estoy pensando $\left.\left.\left.\mathrm{h}_{\mathrm{x}}\right]\right]\right]$ sv [no me hace bien].

Si representamos las oraciones de (89) en una estructura arbórea tendríamos la construcción de (90).

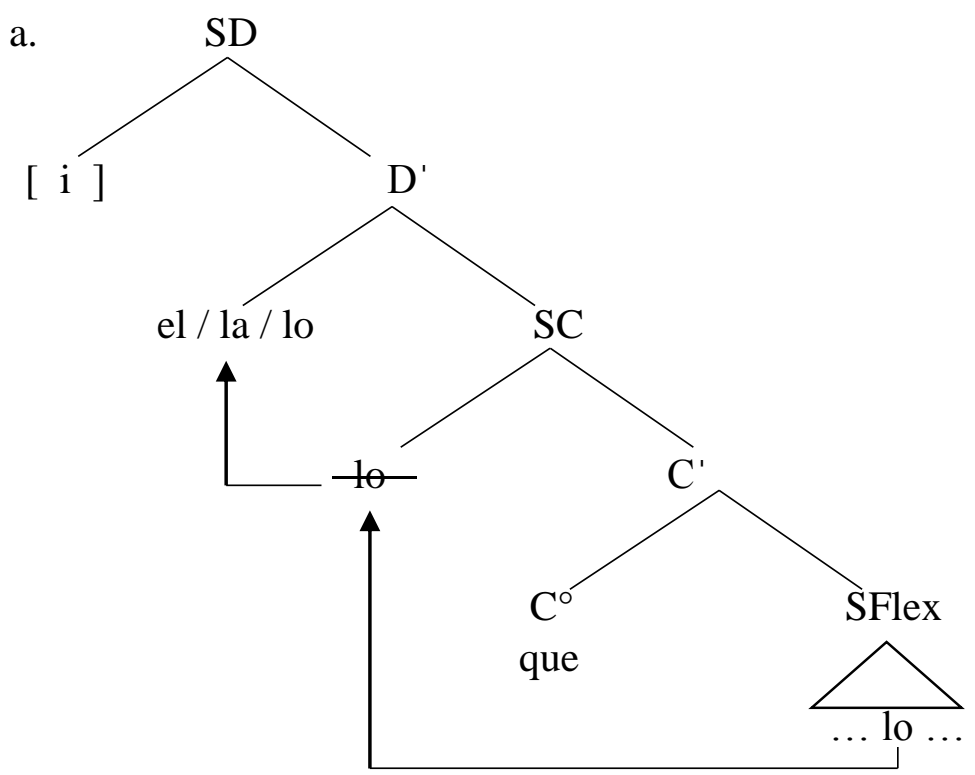

El rasgo [i] que aparece en la estructura arbórea, es un rasgo que tienen los determinantes y los pronombres el cual debe satisfacerse por medio de una oración previa o por contexto. Como se presentó en el apartado 1.1.3.3 donde se habla sobre al análisis de Michael Brame proponía que se borraba el $\mathrm{N}$ del SD, pero no decía el porqué, ahora puedo decir que se borra por la presencia del rasgo [i] que aparece en la estructura del SD. Véase la estructura de (91) 


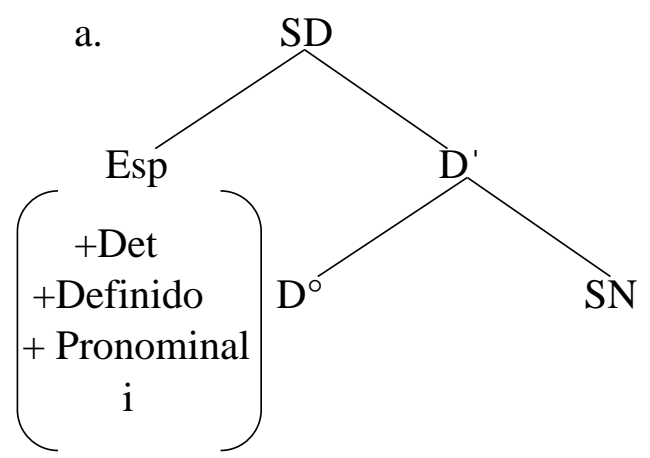

Cuando el determinante se aloja en la posición $\mathrm{D}^{\circ}$ del $\mathrm{SD}$ se checan todos los rasgos que solicita, excepto el rasgo de definitud [i] porque no hay un elemento que pueda checarlo, sino que lo que busca ese rasgo es su referente que no está presente en su categoría rectora. Cabe mencionar que cuando el articulo definido solo unifica o define a un elemento ese rasgo no aparece como se muestra en la estructura de (92).

a.

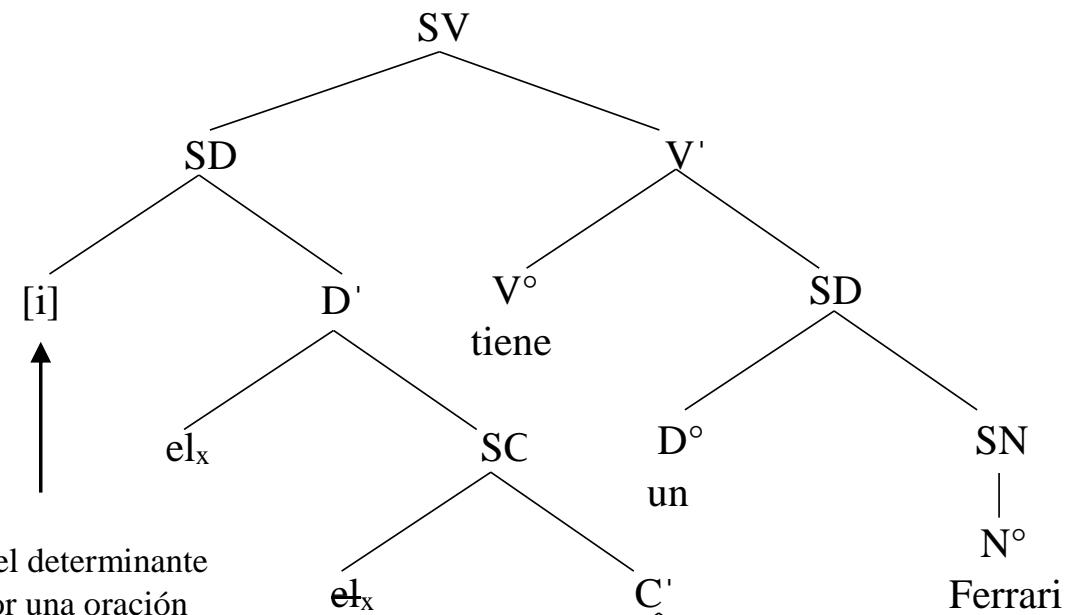

El referente del determinante se satisface por una oración previa o en este caso por el contexto.

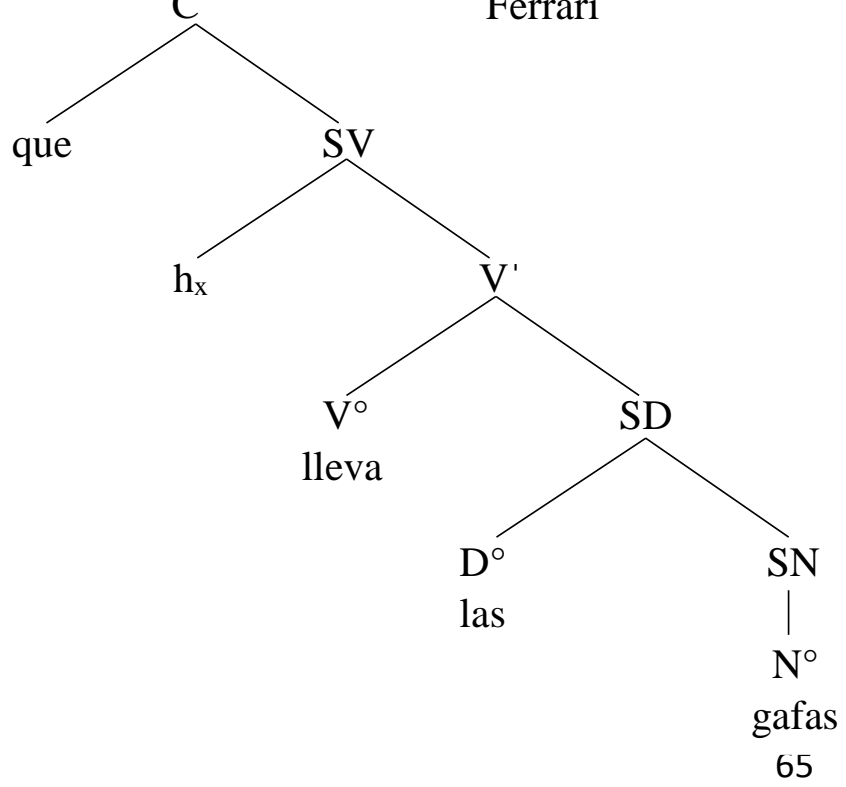


Dentro de las headlees relatives también se pueden encontrar ejemplos con demostrativos los cuales presentan el mismo comportamiento que los artículos determinados, estas estructuras aparecen en (93).
a. Este que viene ha perdido todo.
b. Ese que escucha música canta horrible.
c. Aquel que llegó me cae muy mal.
d. Esta que yo veo es interesante.
e. Esa que se comporta así

Los demostrativos poseen, además del rasgo de definitud, un componente deíctico que permite al hablante situar el referente a mayor o menor distancia del lugar en el que se habla es por eso que se comportan como los pronombres y los artículos determinados. Los demostrativos están sujetos a condiciones de uso más restrictivas que el artículo definido, la información que transmiten es la de que el referente, además de ser identificable, debe ser información familiar para el receptor y accesible en el discurso previo.

Otras estructuras que también involucran a las headless relatives son las que aparecen en (94) la única diferencia con las que ya se presentaron antes es que hay una SD que es la cabeza de este tipo de relativas.
a. El cuchillo con el que lo mataron desapareció.
b. La idea con la que ganó el premio fue maravillosa.
c. Los deportes con los que se entretiene.
d. Un mundo en el que ya no cabemos 
Las oraciones de (94) se pueden analizar con la misma estructura sintáctica ya mencionada a diferencia de que se involucra el movimiento de un constituyente de la oración en este caso la preposición, que debe alojarse en el especificador del SC, ya que en español como se mencionó anteriormente no puede interpretarse abajo, véase la estructura arbórea de (95) para más detalle.

a.

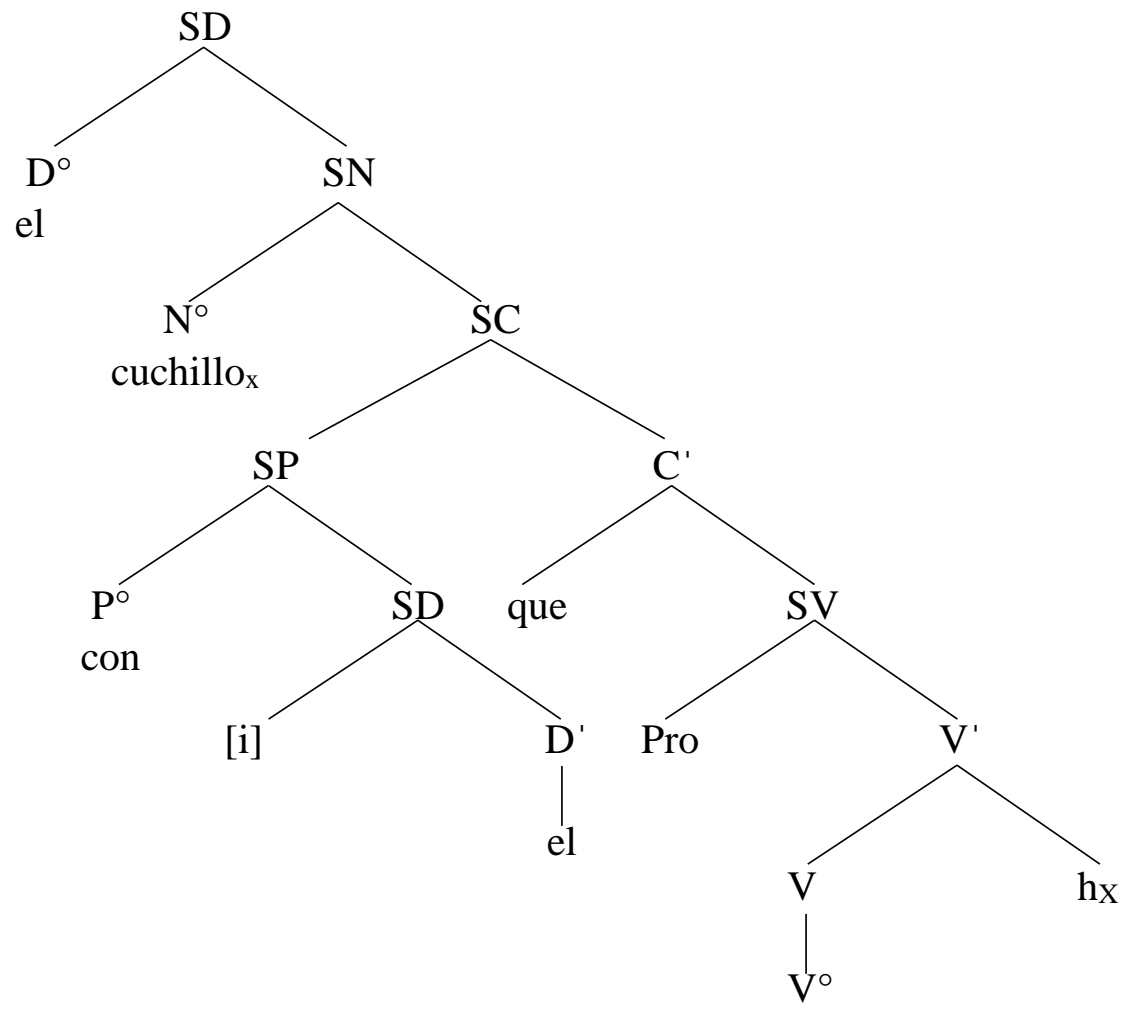

lo mataron 
Capítulo III EL, LA, $L O$ ¿DETERMINANTES DEFINIDOS O PRONOMBRES?

La idea de que determinantes y pronombres son miembros de la misma clase son por las semejanzas que existen entre ellos, algunas de las semejanzas son:

I. Algunos pronombres y determinantes tienen un origen común.

El artículo, conocido como artículo definido, determinado o simplemente artículo, es una creación romance llevada a cabo por todas las lenguas románicas a partir de un demostrativo latino.

El significado esencial, básico y constante del artículo es presentar la entidad nominal que sigue como determinada, conocida, accesible al oyente y próxima a la experiencia. Es una forma que busca su relación hacia adelante en el sintagma, se podría decir que el artículo realiza una especie de presentación o actualización prospectiva, y una vez que presenta a su nominal no queda ningún residuo informativo pendiente, por lo cual esas frases nominales son autónomas referencialmente y no relacionales, de manera que una vez introducido el sustantivo, el oyente o lector posee toda la información necesaria para la adecuada comprensión del sintagma, Company (2007).

\begin{tabular}{|c|c|c|c|c|}
\hline Latín & Ille & Illa & Illud & Demostrativo \\
\hline \multirow[t]{2}{*}{ Español } & el / le & la & lo & Articulo/clítico \\
\hline & él & ella & ello & Pronombre \\
\hline
\end{tabular}

La tabla de (96) nos da cuenta de los artículos y pronombres del español que se originaron a partir de la evolución del demostrativo del latín. 
II. Sus formas coinciden o están emparentadas.

Los artículos y los pronombres pueden coincidir de manera fonética, pero son diferentes en cuanto a su estructura argumental. Para satisfacer su valencia los artículos determinados requieren de un nominal, mientras que los pronombres requieren de un verbo.
a. $\mathrm{SD}=\operatorname{Det}+\mathrm{N}$
b. $\mathrm{SV}=$ Pron $+\mathrm{V}$

Los pronombres clíticos de tercera persona lo y la pueden confundirse claramente con determinantes definidos lo y la. Sin embargo, su estructura es lo que los diferencia uno de otros véase los ejemplos de (98).

a. La compró ayer. (clítico)

La camisa se arrugó. (determinante)

b. Juan lo trajo. (clítico)

Juan vive lo bueno de la vida. (determinante)

III. Su matriz de rasgos es casi idéntica.

Los rasgos gramaticales han tomado una importancia creciente en el desarrollo de la gramática generativa, se parte de la idea de que las piezas léxicas no son más que un conjunto o matriz de rasgos de distinta naturaleza.

Los rasgos de las categorías léxicas y de las categorías funcionales son importantes porque por medio de ella se sabe qué tipo de complemento necesitan para satisfacer su valencia, es decir, para que puedan coocurrir necesitan de un elemento para hacer una proyección sintáctica. La matriz de rasgos de los determinantes definidos e indefinidos y de los pronombres se ejemplifica en (99). 


$$
\left.\begin{array}{c}
\text { Pronombres } \\
+ \text { Pronominal } \\
\text { +Definido } \\
\text { Género } \\
\text { Número } \\
\mathrm{i}
\end{array}\right) \quad\left(\begin{array}{c}
\text { Definidos } \\
+ \text { Det } \\
+ \text { Definido } \\
-\mathrm{N} \\
\pm \text { Pronominal } \\
\text { Género } \\
\text { Número } \\
\mathrm{i}
\end{array}\right)\left(\begin{array}{c}
\text { Indefinidos } \\
\text {-Definido } \\
\text { Género } \\
\text { Número }
\end{array}\right)
$$

IV. La función sintáctica de ambos es la misma

Los determinantes son modificadores que se combinan con nombres para producir expresiones cuya referencia se determina en términos de la identidad del referente véanse los ejemplos de (100).
a. La silla está cubierta de libros.
b. Pon el papel en la mesa.
c. Pon el papel en una mesa.
d. El perro ladra por las noches.
e. La casa tiene una ventana.

Los determinantes de las oraciones de (100) seleccionan e individualizan un subconjunto dentro del conjunto de entidades denotadas por el nombre, en este caso solo estamos cumpliendo con la unicidad del nombre, es decir, el determinante solo está ligado con su núcleo. 
Los pronombres identifican su referencia a partir de su correferencia con un antecedente que se identifica por medio de dos posibilidades:
a. Contexto

Cuando un pronombre obtiene su referencia por contexto nos referimos al contexto extralingüístico que rodea a alguna oración, este puede ser el mundo físico que nos rodea o algún referente que esté a nuestro alcance así se podrá escoger el antecedente más apropiado.

\section{b. Oración previa}

La referencia de un pronombre se puede obtener mediante información exclusivamente sintáctica, admitiendo así la importancia del contenido semántico que se encuentra en la misma oración.

Tómense en cuenta el siguiente grupo de oraciones que muestra cómo se identifica un referente a partir de una oración previa o por contexto.
a. Dale el regalo a ella.
b. Este regalo es para María.

(102)
a. Juan vendrá a la fiesta.
b. Él llegará tarde.
a. Hay una mesa y una silla en mi oficina.
b. Pon el libro en la mesa de mi oficina.
a. Juan compró un perro.
b. compró el que le gusto. 
En las oraciones de (101) y (102) si no conocemos el contexto no sabemos a quién se refiere ella en (101a) y quién es él en (102b), no podemos decir que ella se refiere a María si en una habitación hay más de una mujer, lo mismo ocurre con él no sabemos si se refiere a Juan o a quién, los pronombres deben buscar una referencia en una oración previa o por contexto.

En (103) el uso del artículo tiene la misma función deíctico-pronominal que el pronombre en las oraciones de (101) y (102). Mientras que en (104) se ve claramente que el determinante que aparece en (104b) funciona como pronombre y tiene que buscar su correferencia por el contexto o por una oración previa como (104a) donde claramente ha sido introducido o presentado.

Partiendo de la idea de que determinantes y pronombres cumplen la misma función deíctico-pronominal se puede establecer las siguientes estructuras sintácticas que muestran el comportamiento de los determinantes y pronombres que en páginas posteriores será explicado con más detalle.
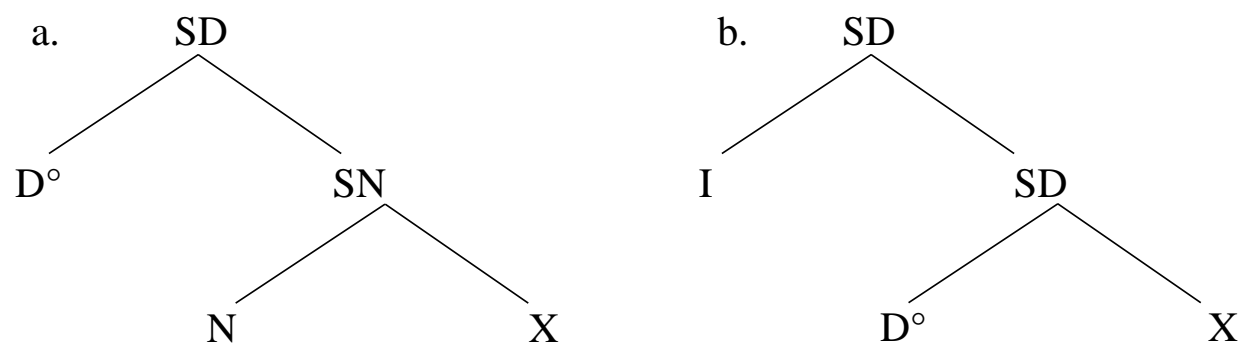

En la estructura sintáctica de (105a) el determinante determina, precisa, especifica o clasifica a algún sustantivo, mientras que en la segunda estructura de (105b) el determinante tiene un rasgo [i] que aparece en su derivación el cual debe ser interpretado por el contexto o por una oración previa, los ejemplos de (106) pueden mostrarlo con más detalle. 
(106)

a. Suj [sD [D [La] $\mathrm{N}[\mathrm{casa}$ azul] $]]_{\mathrm{sv}}[$ tiene fugas en su interior $]$.

b. $\operatorname{Suj}_{[}[\text {Pro] Sv [v [Compré oD [D [el] }]_{\text {Adj }}[$ rojo $\left.\left.]\right]\right]$.

En la oración de (106a) el determinante cumple la función de especificar al nominal haciéndolo definido, mientras que en (106b) el determinante funciona como un pronombre por lo que debe estar presente el índice [i] que nos dice que su referente debe recuperarse por contexto o por una oración previa.

\subsection{Teoría de Rección y ligamiento}

El modelo gramatical de Principios y Parámetros postula cuatro niveles de representación: la estructura-P (E-P), la estructura (E-S), la forma fonética (FF) y la forma lógica (FL). Los dos primeros niveles corresponden al componente sintáctico de la gramática; los dos últimos son sistemas de interpretación y niveles de interfaz con otros sistemas cognitivos. Lorenzo y Longa (1996)

En el modelo de Principios y Parámetros, la teoría de ligamiento es una sub-teoría de la gramática que estudia las relaciones referenciales en las que intervienen factores de carácter sintáctico. Esta teoría cumple dos objetivos:

a. caracterizar a los constituyentes según sus posibilidades referenciales

b. busca determinar las condiciones que los moderan.

Dentro del modelo de P\&P se deben tomar en cuenta dos aspectos importantes que permiten esclarecer el comportamiento de las expresiones referenciales.
a. C-mando 


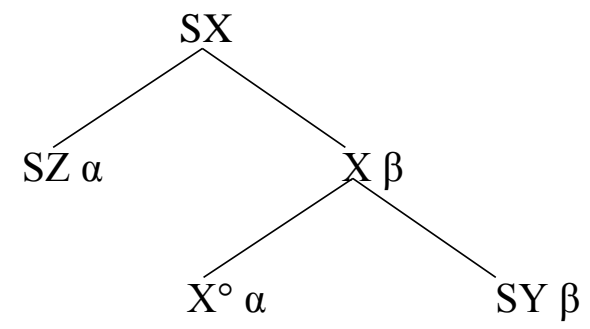

$\alpha$ manda-c a $\beta$ si y sólo si ni $\alpha$ ni $\beta$ se dominan mutuamente y toda proyección máxima que domine a $\alpha$ domina también a $\beta$.

b. Categoría rectora:

$\alpha$ rige a $\beta$ si y sólo si:

a) $\alpha$ manda-c a $\beta$.

b) $\alpha$ es un $\mathrm{X}^{\circ}$ (pertenece a la clase de elementos rectores: $\mathrm{N}, \mathrm{V}, \mathrm{P}, \mathrm{A}, \mathrm{INFL}$ y COMP.

c) toda proyección máxima que domine a $\beta$ domina a $\alpha$.

Los principios de la teoría de ligamiento regulan las condiciones bajo las cuales se dan las relaciones anafóricas entre los elementos nominales de la oración en posiciones argumentales. Dichas condiciones implican aspectos semánticos y estructurales.

Los elementos referenciales dentro de este modelo son de suma importancia, la teoría de ligamiento las clasifica en tres tipos: anáforas, pronominales y expresiones referenciales. Dentro de este modelo generativista los elementos referenciales deben estar ligados a tres principios fundamentales que dan cuenta de las relaciones de dependencia referencial que se establecen entre los argumentos. Tales principios se pueden formular como sigue:

\section{a. Principio A}

Las anáforas deben estar ligadas dentro de su categoría rectora.

\section{b. Principio B}

Los pronominales deben estar libres dentro de su categoría rectora. 


\section{c. Principio C}

Las expresiones referenciales deben estar siempre libres.
a. Anáforas

Se caracterizan con los rasgos [+anafórico] y [- pronominal]. Pertenecen a este grupo los pronombres reflexivos y recíprocos, los cuales necesitan de otro elemento para ser interpretados referencialmente. Deben satisfacer la condición de estar relacionados con su antecedente que ocupa una posición argumental jerárquicamente superior para poder cmandar a la anáfora.
a. Luisi se bañó. $^{2}$
b. * Luis j se bañó a sí mismaj.
c. María ${ }_{j}$ dijo que Lucíai se maquilló a sí misma*j/i.

Podemos observar la oración de (108a) hay correferencia entre el antecedente Luis y la anáfora se ya que ambos elementos comparten los mismos rasgos gramaticales. En la oración de (108b) Luis no puede ser el antecedente de la anáfora por lo que lo hace agramatical y en (108c) si se interpreta a María como el antecedente de la anáfora sería una expresión agramatical, mientras que si se interpreta con Lucia la correferencia es correcta además de que está dentro de su categoría rectora. Por lo tanto, para que una anáfora sea gramatical debe estar ligado con su antecedente en algún lugar de la oración véase la estructura arbórea de (109).

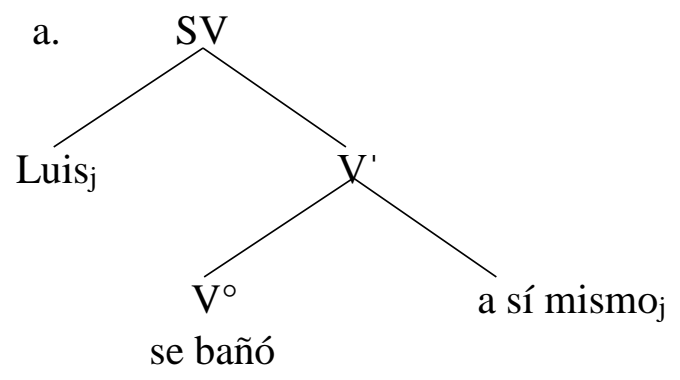



b. Pronominales

Se caracterizan con los rasgos [-anafórico] y [+ pronominal]. Pertenecen a este tipo de elementos referenciales los pronombres que no pueden tener un antecedente dentro de un dominio local. Se puede observar en las oraciones de (110).
a. Rocío loj $_{\mathrm{j}}$ felicitó.

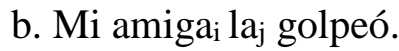

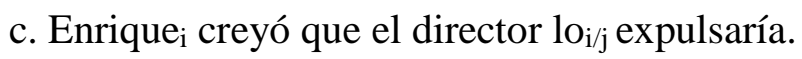
d. *Rocío lo felicito a Juan ${ }_{i}$.

En (110a) y (110b) los pronominales están libres en su categoría rectora y no están ligados a ningún antecedente dentro de la oración que los contiene, en (110c) el pronombre puede estar ligado a un SN que lo c-manda desde fuera de la categoría rectora que, en este caso, es la oración subordinada, mientras que en (110d) la oración no es aceptada porque el pronombre está ligado a un antecedente cuando este debe estar libre en su categoría rectora.

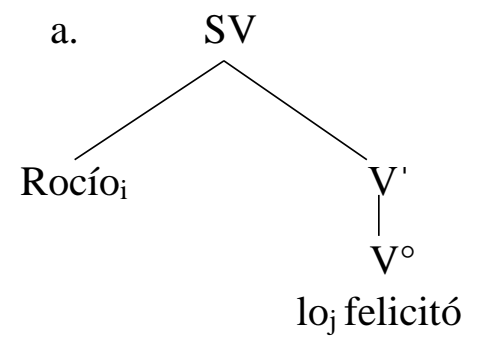

Partiendo de esta noción se puede decir que los determinantes tienen la misma función deíctico-pronominal que los elementos pronominales, considérense los ejemplos de (112).
a. Juan tiene la mesak que tú querías.
b. *Juan tiene una mesa $a_{\mathrm{x}}$ que tú tienes. 
c. Juan vio una mesaj azul, roja y verde. Decidió comprar lajazul.

d. Juan laj ama.

En las oraciones de (112) se ve el contraste entre el uso de los determinantes y los pronombres, ambos buscan un referente que no está dentro de su categoría rectora, sino que esta fuera en un contexto extralingüístico o en una oración previa. En (112a) debe ser una mesa ya antes mencionada por lo que el determinante simplemente cumple la función de especificar pues es el elemento que define al nominal con el que aparece, mientras que en (112b) es agramatical porque debe aparecer el artículo determinado en vez del indeterminado puesto que ambos conocen la mesa de la que hablan. Sin embargo, en (112c) hay una oración previa donde se identifica el referente de la segunda oración por lo que en esta oración el determinante funciona como pronombre al igual que en la oración (112d),

c. Expresiones referenciales

Se caracterizan con los rasgos [- anafórico] y [-pronominal]. Este tipo de elementos debido a su dependencia referencial, no puede tener antecedente ni dentro ni fuera de su dominio local. Las oraciones se presentan en (113).
a. Enrique felicitó a Luis $_{\mathrm{i}}$.

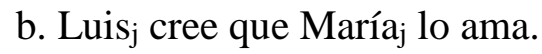
c. Juan ${ }_{\mathrm{i}}$ cree que Juan $*_{\mathrm{i}}$ lo aprecia.

En (113a) y (113b) cumple con los principios ya mencionados, mientras que en (113c) no es correcto tener esa construcción porque Juan no puede tener el mismo antecedente correferencial ni dentro ni fuera de su dominio a menos que se trate de otro Juan. 


\subsection{Los Artículos}

Un artículo es un determinante definido o indefinido que ha desarrollado propiedades especiales que lo hacen virtualmente obligatorio en una serie de contextos sintácticos

De acuerdo a las ideas postuladas por Leonetti (1999) sobre los determinantes, destaca las siguientes características:

a. Forman clases cerradas, integradas por un número limitado de elementos (es especialmente evidente en los demostrativos, los posesivos y los indefinidos).

b. Tienen en general la misma morfología flexiva que los adjetivos, con variación de género y número (en español existen formas neutras de los determinantes, como lo, esto, eso, aquello, que no se encuentran entre los adjetivos).

c. Pueden usarse como pronombres, sin combinarlos con un nombre común. Los determinantes están claramente emparentados con los pronombres, y para muchos autores ambos pertenecen a la misma clase de palabras.

Leoneti (1997) sostiene que el determinante sirve para restringir y definir la referencia de los sintagmas nominales y las entidades a la que los hablantes aluden por medio de tales expresiones. Estas afirmaciones apuntan a que el articulo carece de independencia sintáctica y también de valor semántico, puesto que su valor es pragmático en cuanto que designa una realidad que existe en el universo discursivo que comparten hablante y destinatario y que es accesible para ambos en tanto entidad dada y conocida.

Los determinantes son las palabras que acompaña al nombre para señalar al objeto al que se refiere y concuerda con él en género y número, en español se pueden dividir en definidos (el, la y lo y sus plurales correspondientes) e indefinidos (un, una y su plural correspondiente). 
La propiedad básica de los elementos léxicos con el rasgo [Det] es que, por el hecho de poseer este rasgo, se han de combinar con nombres o proyecciones nominales, es decir, ser determinante significa subcategorizar proyecciones nominales. El valor pragmático del determinante definido está unido a los conceptos de referencialidad, unicidad y $\operatorname{maximalidad}^{23}$.

La suposición estándar dentro de la teoría de estructura de frase situaba en el especificador de los SSNN a los determinantes definidos e indefinidos dentro su proyección como se ejemplifica en la estructura arbórea de (114).

a.

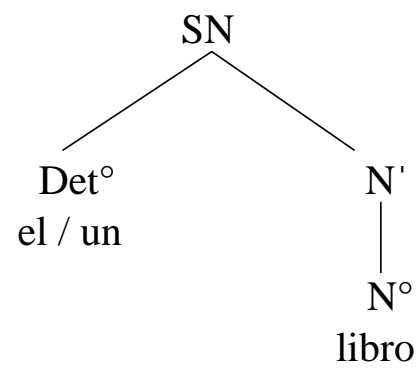

Sin embargo, Abney (1987) propuso la hipótesis de la Frase determinante donde el determinante en sí es la cabeza de una frase nominal y no al revés como se trataba en análisis anteriores, véase la estructura de (115) que muestra está hipótesis.

a.

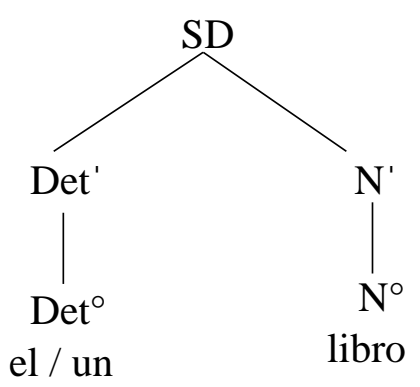

${ }^{23}$ Implica la totalidad de un conjunto existente en un mundo. 
Hernanz y Brucart (1987) postularon dos peculiaridades sintácticas que nos sirven como diagnóstico para individualizar la clase de los determinantes del español:

a) Su ausencia provoca resultados agramaticales en ciertos contextos por ejemplo cuando preceden a nombres con función de sujeto oracional.

b) No necesitan de ningún otro determinante para producir expresiones bien formadas.

\subsubsection{Artículos definidos (el, la, lo) e indefinidos (un, una)}

El español es una lengua que marca explícitamente la distinción definido / indefinido en su sistema de determinantes. El papel de los determinantes es el de establecer la forma de identificar o localizar entidades en un mundo posible ya que los determinantes seleccionan e individualizan un subconjunto dentro del conjunto de entidades denotadas por el nombre y sus modificadores para referirse a él como una entidad.

La distinción entre ambos tipos de determinantes es que los elementos definidos poseen un rasgo de definitud del cual carecen los indefinidos.

El artículo definido o determinado se refiere, generalmente a seres o cosas previamente identificadas o conocidas por los hablantes, mientras que el artículo indefinido se refiera a cosas no conocidas, como se ejemplifica en (116)
a. $L a$ luna es el satélite natural de la tierra.
b. Un joven vino a pedir su mano. 
En la oración de (116a) el determinante la define al nominal que le precede, es algo que ya se ha identificado con anterioridad y ambos hablantes saben de qué se habla, mientras que en (116b) no ocurre lo mismo porque el determinante un no identifica a un referente.

El artículo definido al categorizar a un nominal produce expresiones referenciales, es decir, están ligadas a un referente que previamente ya se ha mencionado. Como se mencionó previamente el artículo definido debe tener un referente que se puede satisfacer de dos maneras por contexto o sintácticamente por una oración previa como se ejemplifica en las oraciones de (117).
a. Juan vio un auto rojo y un azul, decidió comprar el rojo.
b. El libro que me recomendaste es buenísimo.

Como se muestra en la oración de (a) el referente de el es un auto rojo que previamente ya se ha introducido en la primera oración, por lo tanto, es fácil identificar el referente del determinante, mientras que en (b) el referente tendrá que ser obtenido por contexto porque no se menciona en la oración cual libro, pero es algo el oyente intuye pues ambos saben de qué hablan.

Los artículos determinados poseen rasgos que los caracterizan y los diferencian de los artículos indeterminados. Un rasgo universal importante que todos los artículos poseen es el [+Determiante], para satisfacer su valencia siempre requerirá de un nominal [_Nom], al igual que los pronombres y algunas otras categorías flexivas poseen género [Masc. / Fem], número [Sing. / Pl.]. Los determinantes definidos cuentan además con un rasgo que a mi parecer es uno de los más importantes, este rasgo se representa como [i] el cual debe satisfacerse por dos diferentes medios, por contexto extralingüístico o por contexto oracional este rasgo está unido a lo que se conoce como definitud la cual establece que el referente del SN se identifica 
claramente por el receptor en el contexto de uso, esto es conocido como condición de unicidad, estos rasgos están presentes en su estructura argumental como se ejemplifica en (118).

(118)

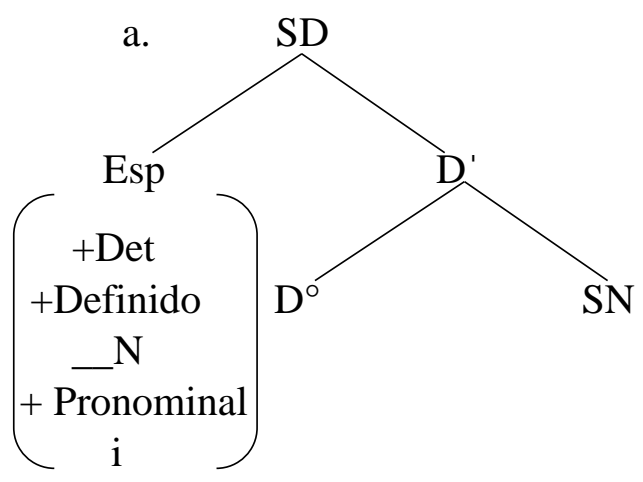

(119)
a. sD $\left[\mathrm{D}[\mathrm{La}]_{\mathrm{i}}\right.$ [cerveza $\left.]\right] \mathrm{sv}$ [está muy fría].
b. SD [D $[\mathrm{El}]_{\mathrm{i}} \mathrm{N}[$ tucán $\left.]\right]$ sv [tiene un plumaje hermoso].

Las oraciones de (119) son entendibles para cualquier hablante de español porque conocemos el referente de cada una de las oraciones y aunque no esté presente en el momento del habla sabemos a qué se refiere porque satisfacemos el rasgo [i] por contexto extralingüístico o por conocimiento enciclopédico. Ahora bien, si prescindimos del artículo en las oraciones de (119) serían agramaticales como se ejemplifican a continuación en (120).
a.* Cerveza está muy fría
b. *Tucán tiene un plumaje hermoso. 
En español cuando un nominal tiene alguna función gramatical dentro de la oración no puede aparecer sin un determinante, esto nos hace pensar que efectivamente el determinante es el que da la definitud y no el nominal como se suele pensar, es decir, el determinante siempre está presente para dar la información restrictiva necesaria para que se pueda identificar la referencia y así satisfacer el requisito de unicidad del nominal que por sí solo no es capaz de proyectar en una estructura sintáctica.

Para que un nominal tenga el sentido de definitud debe aparecer siempre con un artículo determinado, aunque si puede haber nominales que aparezcan sin un determinante, mejor conocidos como nomíneles escuetos ${ }^{24}$, pero tienen una lectura colectiva como las oraciones que se presentan en (121)
a. Tiro balas al aire.
b. Trajo bebidas para todos.
c. Compro mantequilla para el pastel.

Siguiendo con esta idea los demostrativos (ese, este y aquel) tienen un comportamiento similar a los artículos determinados, es decir, los demostrativos tienen un componente deíctico que permite al hablante situar el referente a mayor o menor distancia del lugar en el que se habla, pero también poseen el rasgo de definitud al igual que los determinantes definidos, por lo que deben tener un referente que se satisface por contexto u oración previa, véanse los ejemplos de (122).

a. Suj $\left[\mathrm{SD}[\mathrm{D}[\text { Ese }]]_{\mathrm{N}}[\right.$ hombre $\left.]\right] \mathrm{sv}$ [es mi tío].

\footnotetext{
${ }^{24}$ No se indagará nada sobre este tipo de nominales.
} 
b. Suj [Juan] sv [dio de comer SP [a SD [D [este] N [animalito]]]].

c. Suj $[\mathrm{sD}[\mathrm{D}[$ Aquel $] \mathrm{N}[$ niño] $]$ sv [tiene una sonrisa apagada $]$.

La interpretación que transmiten los demostrativos en las oraciones de (122) obligan a buscar al referente en un contexto inmediato haciéndolo identificable, además debe ser información familiar para el receptor y debe ser accesible para que tenga sentido.

El artículo indefinido realiza la función de actualizador del sustantivo o de un elemento sustantivado. No es compatible con otros determinantes, excepto cuando sigue a todo y casi como se muestra en (123).
a. Es todo un hombre.
b. Es todo un sueño.
c. Ya es casi un hombre.

Los que muestran las oraciones de (123) es que el indefinido solo introduce un elemento sin referencia alguna. Aunque también puede denotar singularización, es decir, de entre un conjunto elige a uno y lo hace único como se muestra en las oraciones de (124).
a. Ladra un perro.
b. Ganó el premio un estudiante de la secundaria.

El papel esencial de un en las oraciones de (124) consiste en generalizar un elemento de un conjunto más grande. La ausencia de definitud en los artículos indefinidos indica simplemente que se debe tomar un elemento de la clase denotada por el nombre, sin que haya garantía de identificabilidad del referente para el receptor. Esto da lugar a distintas interpretaciones en función del contexto gramatical y discursivo: inespecífica, específica o genérica 
La distinción entre determinantes definidos y determinantes indefinidos se manifiesta en un buen número de fenómenos gramaticales, entre ellos están las propiedades anafóricas que son correferenciales, es decir, solo los SSNN definidos pueden ser anafóricos y retomar antecedentes discursivos, mientras que los SSNN indefinidos se emplean para introducir referentes nuevos en el discurso, la posición dentro del SN, y las llamadas restricciones de definitud.

\subsubsection{El determinante con valor de definitud}

La definitud funciona como una instrucción abstracta sobre la forma en la que debe interpretarse un SN. La definitud es la indicación de que el referente del SN es identificable o interpretativa de forma unívoca, es decir, sin ambigüedad para el receptor en el contexto de uso. Esta condición es común a todas las expresiones definidas, y se denomina Condición de Unicidad.

Lyons (1999) señala que las dos nociones centrales que se han manejado para acotar el significado del artículo definido son las de familiaridad o identificabilidad, por un lado, y unicidad o inclusividad, por otro. La condición de unicidad del definido puede ser expresado en diversas situaciones oracionales.

I. Uso deíctico: La situación física en la que se encuentran los participantes contribuye a la identificación del referente denotado por el nominal.

a. Coloca el libro en la mesa.

En la oración (125) la mesa es un lugar deíctico es algo que el oyente está viendo, sabe dónde está dicha mesa o el interlocutor la está señalando. 
II. Conocimiento enciclopédico: El referente proviene de conocimientos generales extralingüísticos es algo que ya sabe o intuye el oyente.

a. Ayer la luna brillaba más que nunca y tú no la viste.

En la oración anterior de (126) no es necesario que el oyente vea el referente ahí mismo porque es una entidad que el hablante y el oyente se supone que conocen porque comparten determinados conocimientos sobre el mundo.

III. Uso anafórico: el referente del $\mathrm{SN}$ es identificado o conocido porque ya fue introducido previamente en un contexto lingüístico.

a. Luis se compró una moto y un carro. Sin embargo, siempre usa más la moto. En la oración de (127) el referente de la moto ya ha sido introducida previamente, es por eso que el oyente puede identificar claramente el referente en la misma oración.

La condición de unicidad es la esencia de la definitud ya que permite explicar todos los usos e interpretaciones posibles de los SSNN encabezados por el artículo definido. El significado del artículo es invariable, pero la demanda de unicidad se satisface de diferentes formas al interpretar el SN en un contexto.

\subsubsection{El determinante con valor de pronombre}

Abney (1987) argumenta la propuesta de que el determinante encabeza frases nominales, esta idea nos permite recoger de manera explícita e inequívoca el hecho de que los determinantes y los pronombres son miembros de una misma categoría gramatical. Por lo tanto, propone que los pronombres son determinantes. 
Abney asegura que los pronombres aparentemente sólo están en distribución complementaria con los demostrativos y no con los artículos y que los rasgos phi y el caso está en el determinante y no en el nombre. En español también podemos evidenciar que estos rasgos efectivamente se encuentran en el determinante.
a. *día amaneció nublado.
b. casa

Las oraciones de (128) muestran que efectivamente un nombre carece de definitud por sí mismos, es por eso que requieren de un determinante para que puedan tener una función sintáctica, pero sobre todo una referencia y es en ese sentido que el determinante tiene un uso deíctico-pronominal como los pronombres.

Los determinantes definidos y los pronombres son elementos gramaticales con contenido procedimental. Su función es la de expresar restricciones sobre el proceso inferencial de construcción de la proposición comunicada y constreñir de esta forma la búsqueda de referentes y de antecedentes para las expresiones anafóricas, por lo que el determinante puede funcionar como un pronombre lo que nos da la oportunidad de tener dos estructuras sintácticas deferentes, véase las estructuras de (129).
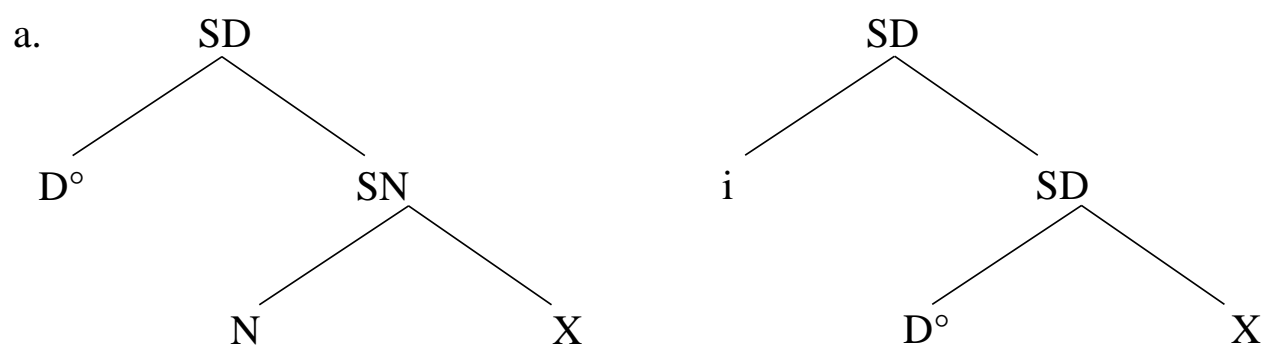
En (129a) la función del determinante es solo satisfacer el requisito de definitud del sustantivo que es su núcleo, mientras que en (129b) tiene la función de pronombre al aparecer en la configuración un rasgo [i] que indica que hay un referente.

Las oraciones que se presentan en (130) muestran el comportamiento similar de un determinante a un pronombre.
a. Él $x_{x}$ se compró una manzana
b. El $l_{x}$ hombre se compró una manzana.
c. El $\mathrm{x}_{\mathrm{x}}$ de la camisa se compró una manzana.

En la oración de (130a) el pronombre debe tener un referente, no está presente en la oración por lo que debe estar en un contexto cercano a la persona que dice la oración, la oración (130b) el nominal por sí solo no tiene definitud por lo que el determinante lo satisface con este rasgo y además identifica de qué hombre se habla, ahora bien, si analizamos la oración de (130c) el determinante no tiene un referente en la oración en la que se encuentra, no sabemos de quién se habla, pero tiene una lectura deíctica que nos indica que el referente está presente en un contexto cercano, es en ese sentido que los pronombres y los determinantes tienen la misma función deíctico-pronominal para identificar su referente.

Los pronombres y los determinantes se apegan al principio $B$ de la teoría de ligamiento que se encarga de controlar las relaciones de correferencia de los pronominales de una oración, es decir, no tienen un antecedente dentro de su dominio local, sino que su referente se obtiene por medio del contexto o por una oración previa. 
(131)

a.

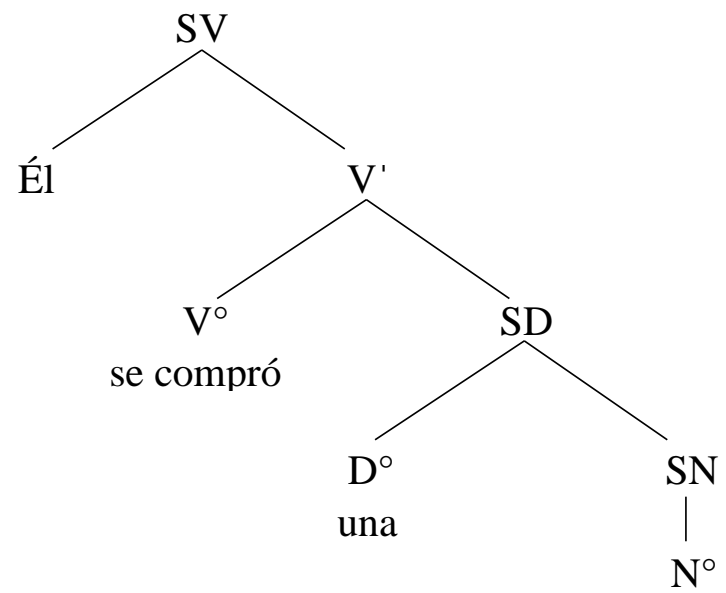

b.

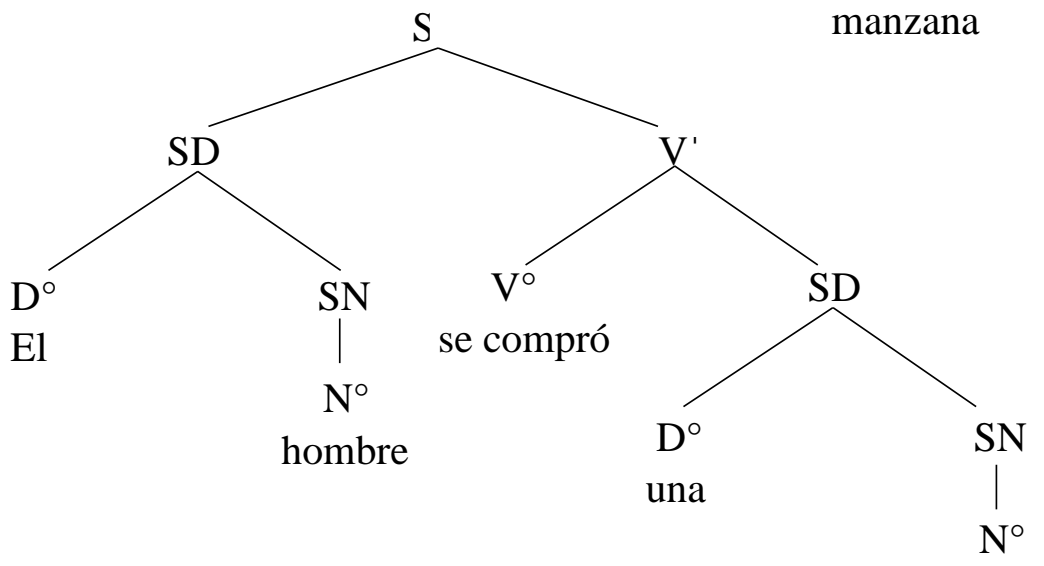

c.

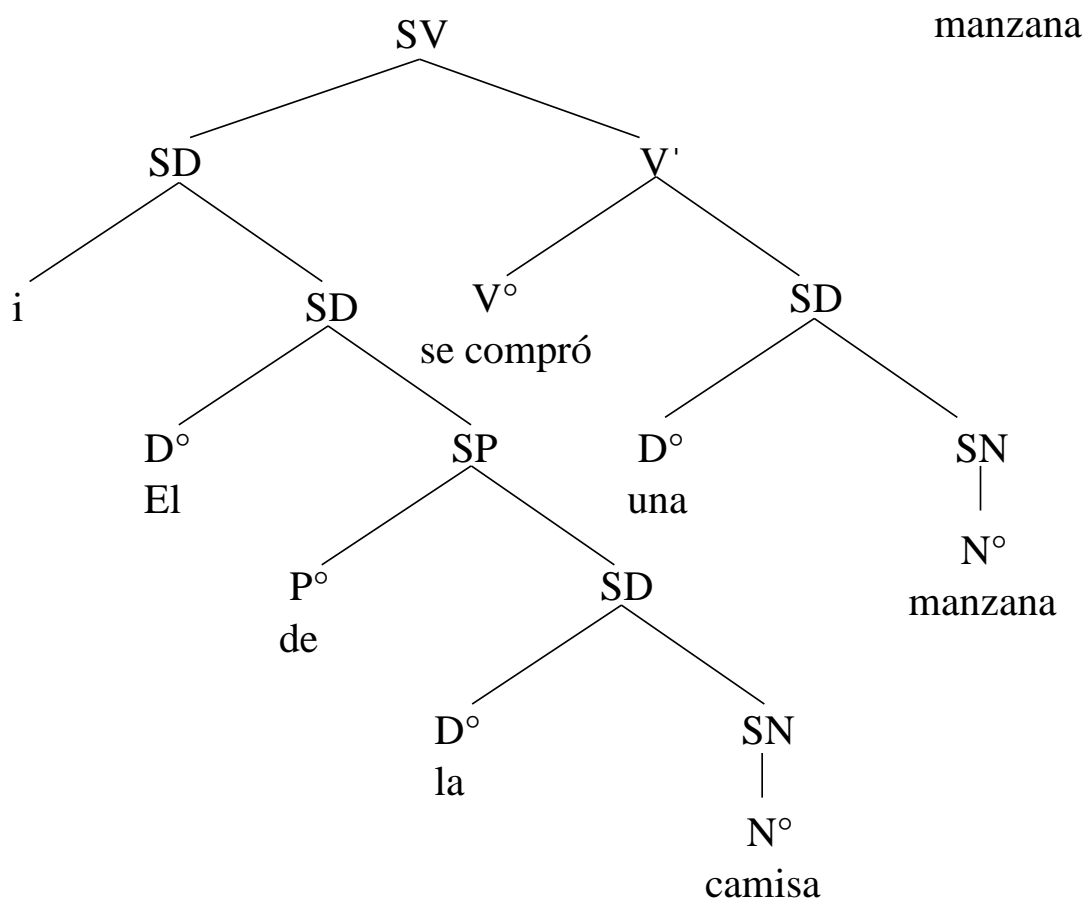


Cuando el determinante tiene la función de pronombre debe aparecer un rasgo [i] forzosamente en su estructura, este rasgo nos permite identificar que se trata de un determinante en función de pronombre y que por el rasgo de definitud es capaz de identificar a un referente de manera única ya que el determinante contiene la información gramatical para que el receptor pueda restringir la construcción que le lleve a realizar una interpretación adecuada del referente.

\subsubsection{Fenómenos de definitud y la elección del modo en las clausulas relativas.}

El modo revela la actitud del hablante ante la información otorgada, es decir, su punto de vista sobre el contenido de lo que se presenta o se describe. En español tenemos modo indicativo, subjuntivo e imperativo.

El modo indicativo se usa, generalmente, para referir hechos reales ya sea en pasado, presente o futuro.
a. Luis trabaja demasiado.
b. Le gustaban las películas de amor.
c. Iremos a las playas de Cancún.

El modo subjuntivo se emplea generalmente para expresar una acción posible, expresar deseo o duda de un evento.
a. Ojalá venga pronto
b. Probablemente no venga mañana
c. No sé si haya terminado el trabajo. 
El modo en las oraciones relativas depende en casi todos los casos de que se asevere o no la existencia del SN que funciona como el antecedente en el contenido de la relativa. Cuando el SN de la cláusula relativa es especifico, es decir, se tiene la certeza de que existe en un mundo posible se hace uso del modo indicativo, mientras que, si el SN es inespecífico y la entidad no existe o el hablante no puede o no quiere afirmar su existencia se usa el modo subjuntivo como los ejemplos que aparecen en (134).

a. Busca el libro que trata sobre la felicidad. (Ind)

b. Busca un libro que trate sobre la felicidad. (Sub)

En (134a) el emisor sabe de qué libro se trata pues tiene el conocimiento de que existe, mientras que en (134b) no se sabe con exactitud si tal libro existe.

Hay hechos como las oraciones de (135) que nos obligan a suponer que el tipo de determinante que encabeza un SN condiciona la presencia y la interpretación de los posibles modos (subjuntivo e indicativo) del español.

a. Busco al hombre que habla español. (Ind)

b. Busco a un hombre que hable español. (Sub)

c. Busco al hombre que hable español. (Sub)

d. Busco a un hombre que habla español. (Ind)

Pero la pregunta que queda para la posterioridad es ¿Cuál es la alternancia que subyace el uso de modo indicativo o subjuntivo con los artículos determinados e indeterminados? La estructura arbórea que se propone para un análisis posterior es la que se presenta en (136). 
(136)

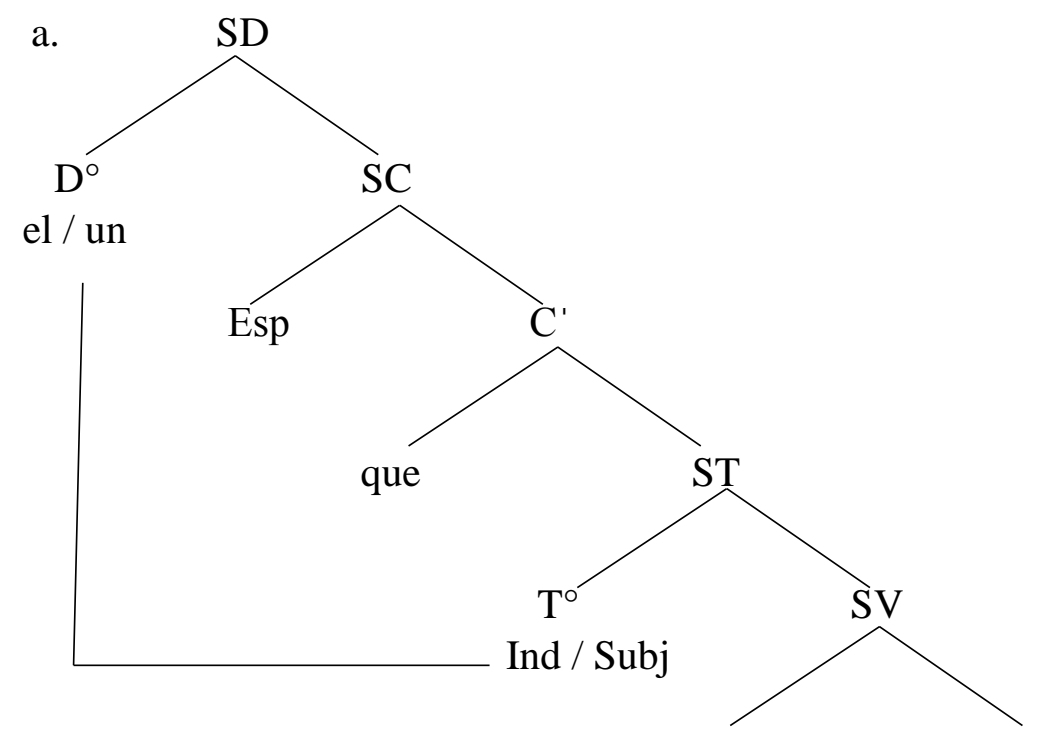

También en construcciones con headless relatives presentan el mismo fenómeno de la alternancia entre modo indicativo y subjuntivo véase las oraciones de (137).
a. $E l$ cuchillo con el que se corta el pan. (Ind)
b. Un cuchillo con el que se corte el pan. (Sub)
c.? El cuchillo con el que se corte el pan. (Sub)
d. Un cuchillo con el que se corta el pan. (Ind)

Los datos de (137) muestran un fenómeno muy interesante que al parecer el uso del artículo determinado y el artículo indeterminado del antecedente es el que determina el modo de la oración subordinada. Sin embargo, hay restricciones que se deben cumplir y que no están muy claras en este análisis. En los ejemplos anteriores se puede observar que el artículo el implica el uso de indicativo como se muestra en los datos de (137a), mientras que el artículo indefinido un implica el uso de subjuntivo e indicativo como se muestra en (137b y d) respectivamente, mientras que en (137c) no es muy aceptable usar el determinante con subjuntivo. 
La estructura que pudiera dar cuenta de esta alternancia se ejemplifica en (138) que es una adaptación a la presentada en (136) sin embargo la única diferencia es que en el Espec del SC se aloja el SP porque en español no puede interpretarse en su posición de origen pues cuando se da el movimiento del constituyente sube junto con la preposición es lo que se conoce como Pied-Piping, sin embargo queda por esclarecerse por qué el determinante definido de la segunda posición no juega un papel importante en la relación que determina si se usa modo subjuntivo o indicativo, aunque se ubica en una posición más cercana al SC y al ST.

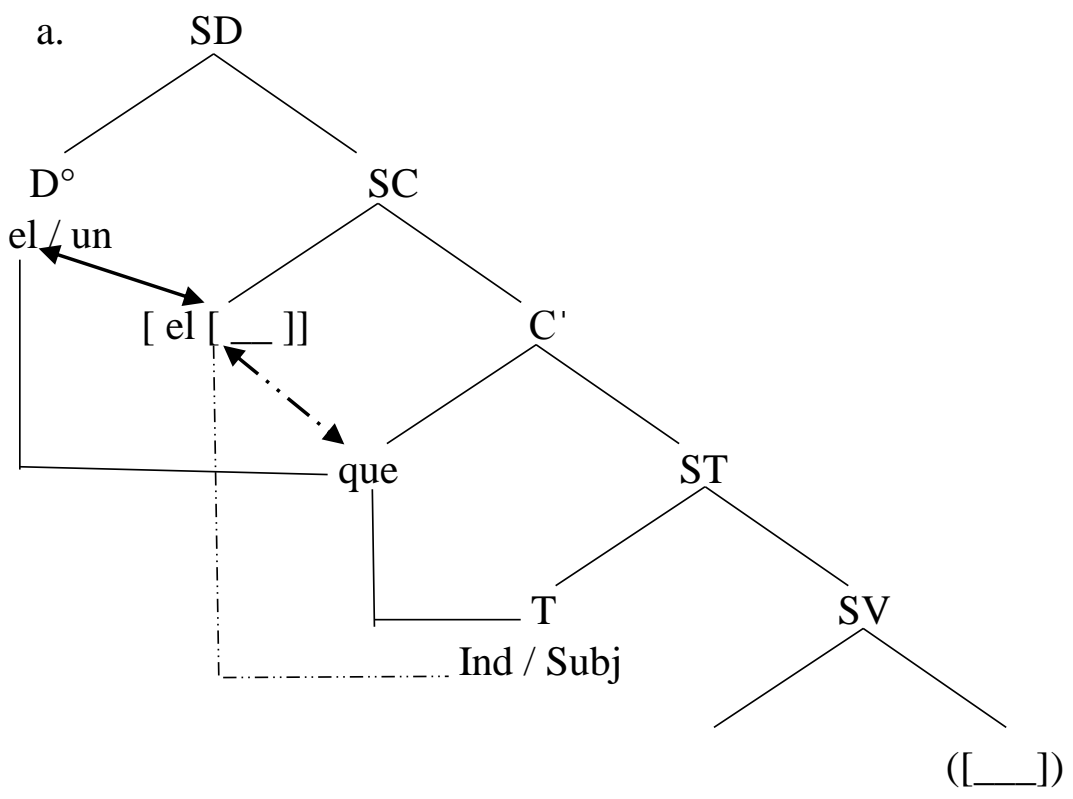

Aunque se pudiera llegar a una caracterización unitaria sobre si en realidad el determinante es el que influye en el modo que toman las cláusulas relativas aun nos quedaría investigar cual es la verdadera naturaleza del fenómeno gramatical que subyace a esta alternancia entre modo indicativo y subjuntivo. 


\section{CONCLUSIONES}

En la presente investigación se abordó el estudio de las cláusulas relativas introducidas por que el cuál debe ser considerado como un complementante en español, en este trabajo se presentaron mecanismos que lo diferencian de los que sí son pronombres relativos. El objetivo principal era analizar las headless relatives y la naturaleza del elemento que le antecede en las construcciones presentadas durante toda la investigación. Para ello se partió de los principios teóricos sobre el análisis de las cláusulas relativas y los rasgos que caracterizan a los determinantes para poder esclarecer la naturaleza del determinante en estas construcciones.

La descripción de las clausulas relativas especificativas se llevó a cabo separando y analizando las construcciones relativas con antecedente y sin antecedente para poder determinar las características sintácticas que presentan cada una y ver si de alguna manera se podía establecer un análisis general que diera cuenta del comportamiento de las relativas con antecedente y de las Headless relatives.

Al tratar como complementante a que se determinó que este elemento no puede estar coindizado con un referente al carecer de rasgos léxicos y flexivos pues es solo el que introduce cláusulas relativas y que lo que se mueve es el argumento del verbo que guarda relación entre la cabeza de la relativa, el elemento que se mueve al Espc del SC y su posición de origen.

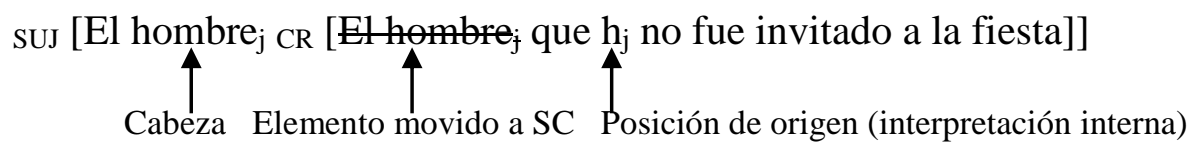

Los argumentos para tratar a que como complementante son: no recibe caso como los pronombres, no tiene género, ni número y uno de los principales argumentos es que no puede 
coocurrir solo en posiciones argumentales como por ejemplo en la de sujeto a diferencia de otros relativos que sí se lo hacen, para que el complementante pueda coocurrir debe estar licenciado por un artículo determinado.

Para este tipo de estructuras se presentaron los principales análisis como el Matching analysis, Raising analysis y análisis posteriores que tratan de dar cuenta del comportamiento de este tipo de relativas determinando que el análisis propuesto por Michel Brame era el indicado para hacer el análisis de este tipo de construcciones haciéndole algunas adecuaciones para el español.

En el apartado de la headless relatives se consideraron los análisis que han abordado este tipo de estructuras entre los que destacan los siguientes:
a. SD $[D \text { el } \emptyset]_{i}\left[q u e . . . h_{i} \ldots\right]$ SD con un vacío en el núcleo.
b. SD [D el hombre $]_{i}\left[q u e . . . h_{i} \ldots\right]$ elisión del nominal
c. SD $\left[\mathrm{el} \mathrm{que}_{\mathrm{i}} \ldots \mathrm{h}_{\mathrm{i}} \ldots\right]$ que como pronombre
d. SD [el Proi que... $\left.h_{i} \ldots\right]$ SD con una categoría vacía Pro.

Sin embargo, durante el análisis de las diferentes propuestas para las headless relatives se determinó que ninguno de los análisis anteriores daba cuenta de la naturaleza del determinante en este tipo de estructuras por lo que se propuso el análisis donde se postula al determinante como un pronombre.

$$
\text { e. } \mathrm{SD}[\mathrm{D} \text { el] }]_{\mathrm{i}}\left[\text { que... } \mathrm{h}_{\mathrm{i}} \ldots\right]
$$

Este análisis nos llevó a considerar dos estructuras para los artículos determinados. En la primera de ellas el artículo solo define la identidad del nominal al que le precede y la segunda es que en su estructura debe aparecer un rasgo [i] que nos permite analizar al artículo como pronombre pues en él se encuentra el rasgo de unicidad y definitud los cuales deben tener una referencia que se recupera por contexto o por una oración previa. 

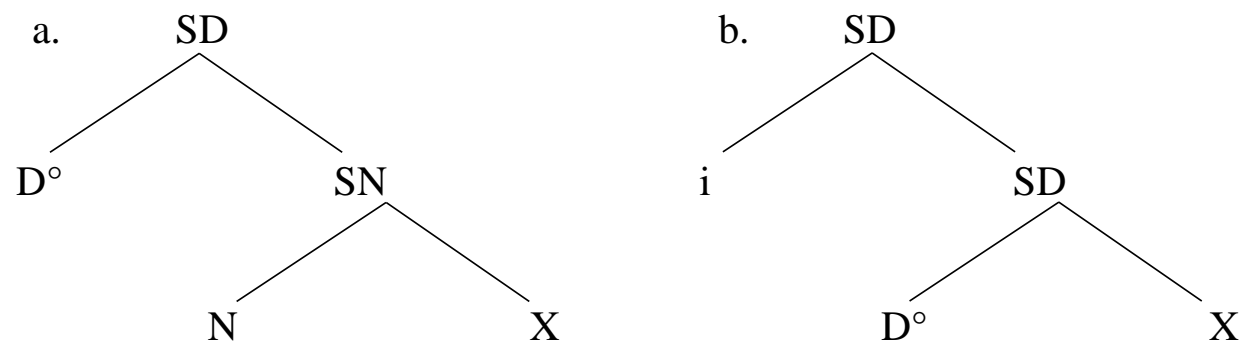

Para sostener está idea se basó en la hipótesis del SD planteada por Abney (1987), pues las relativas restrictivas o especificativas son complementos, seleccionados por un $\mathrm{N}$, dado que aportan información que restringe el significado intencional de la expresión referencial. La posición estructural del determinante tiene la particularidad de que son referenciales por sí mismos y en varios casos están ligados a una expresión nominal referencial, denominada antecedente, la interpretación de la identidad referencial entre el determinante y su antecedente en ocasiones no comparten el mismo dominio, es decir, no están presentes en la oración sino que esta debe estar en un contexto o en una oración previa, es decir, son expresiones ligadas, similares a los pronombres anafóricos de ahí que se concluya que los determinantes y los pronombres tengan la misma función deíctico-pronominal.

Se logró establecer los rasgos principales que caracterizan a los artículos determinados [+Det], [+Definido], [ \pm Pronominal], [Género], [Número] y [i], para los indeterminados [+Det], [-Definido], [Género] y [Número] y finalmente, los pronombres [+Pronominal, [+Definido], [Género]. [Número] y [i]. De acuerdo a los rasgos presentados es evidente que los artículos definidos y pronombres coinciden en varios rasgos, especialmente el rasgo [i] que indica que hay un referente.

Todo lo anterior se sustenta en el modelo del marco generativo que presenta Chomsky (1988) en principios y parámetros, específicamente en la teoría de ligamiento que estudia las relaciones referenciales de los constituyentes de la oración. 
Los determinantes definidos pueden regirse por el principio B de la teoría de ligamiento porque se comportan como los pronombres cuya referencia se determina a partir del contexto o de una oración anterior. Tal principio formula lo siguiente: los pronominales deben estar libres dentro de su categoría rectora y los determinantes cumplen con este principio por lo que se concluye que efectivamente el artículo determinado también tiene la función de pronombre.

La estructura siguiente es la propuesta por Michael Brame con algunas adecuaciones que se realizaron como la inserción del análisis propuesto, donde el artículo definido puede funcionar como un pronombre el cual nos permite analizar las diferentes estructuras relativas en las que se involucra un elemento definido $(e l, l a(s)$ y $l o(s))+q u e$ como se muestra a continuación.

a. El que llegó tiene un Ferrari.

b. Este que llegó tiene un Ferrari.

c. El hombre con el que llego tiene un Ferrari.

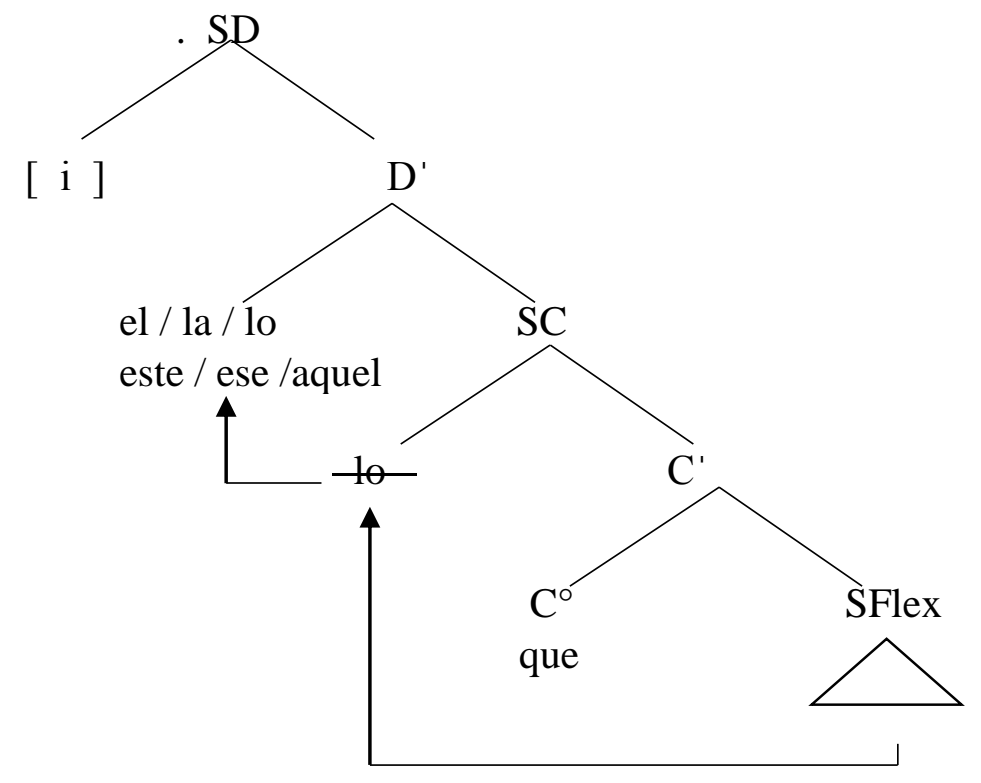


Este análisis abrió la brecha para una nueva investigación sobre el modo en la relativas que no queda claro si el artículo definido es el que licencia el modo indicativo o subjuntivo. De hecho, hay más ejemplos que muestran que la mayoría de las oraciones de relativo aparecen en indicativo y son poco frecuentes las de subjuntivo.

A simple vista se puede pensar que el modo indicativo es requerido cuando en la cabeza de la relativa hay un determinante definido y por otro lado, si en la cabeza de la relativa hay un artículo indefinido aparecerá modo indicativo.

Finalmente, la hipótesisı planteada al principio de este trabajo resultó ser verídica porque el determinante puede tener dos funciones sintácticas dependiendo del uso en diversas estructuras en las que se encuentre, como un determinante pleno cuando solo define la identidad de un nominal y como un pronombre al aparecer en su estructura un rasgo [i] que indica la unicidad y definitud del elemento que se recupera por contexto o por una oración previa, se desechó la idea de concebir al determinante como débil y fuerte. La hipótesis2 se sostuvo mediante las pruebas que se presentaron para tratar al relativo que como un complementante el cual funciona como mero nexo de oraciones subordinadas relativas en español. 


\section{BIBLIOGRAFÍA}

- Alarcos (1967), “El artículo en español”, en E. Alarcos Llorach (1978)

- __ (1994). Gramática de la Lengua Española. Editorial Esparsa-Calpe, S.A, Madrid, España.

- Aguilar-Guevara, A. Curso definidos débiles. UNAM (2018).

- Andrews, Avery D. (2007). "Relative clauses", en Language Typology and Syntactic Description, editado por Timothy Shopen, Vol. II: Complex Constructions, Cambridge: Cambridge University Press.

- Bello, Andrés (1847), Gramática de la lengua castellana destinada al uso de los americanos, ed. de R. Trujillo, Madrid, Arco-Libros, 1988.

- Bosque, Ignacio. (1990), "Las bases gramaticales de la alternancia modal. Repaso y balance". Indicativo y subjuntivo, I. Bosque (ed.), 13-56. Madrid: Taurus.

- Bosque, I. y Gutiérrez-Rexach, J. (2009) Fundamentos de sintaxis formal, Madrid: Akal. Cardinaletti, A. (1994) "On the internal structure of pronominal DPs", The Linguistic Review, 11, pp. 195-219.

- Brucart, J. M. (1992): "Sobre el análisis de las construcciones enfáticas con artículo y cláusula de relativo", Gramma-Temas, 1, pp. 39-63

- _ (1999). La estructura del sintagma nominal: las oraciones de relativo. En: Bosque, Ignacio y Violenta Demonte (eds). Gramática descriptiva de la lengua española. Vol. 1. Madrid: Esparsa.

- __ Some asymmetries in the functioning of relative pronouns in Spanish. Revista Catalana de Lingüística. 
- Cinque, Guglielmo. (2009). The Fundamental Left-Right Asymmetry of Natural Languages. In S.Scalise, E.Magni, A.Bisetto, eds., Universals of Language Today. 165-184. Dordrecht: Springer. (also in G.C. Typological Studies. Word Order and Relative Clauses. London: Routledge, 2013). http://lear.unive.it/jspui/handle/11707/99

- _ (2011). On double-headed relative clauses. Lingüística. Revista de

Estudos Linguísticos da Universidade do Porto 6.67-9

file:///C:/Users/utente/Downloads/DoubleHeadedRCs.pdf

- _ (2015), " Three Phenomena Discriminating between Raising and Matching Relative Clauses", Ca’ Foscari University, Venice, Italy.

- Demonte, Violeta. (1994). Teoría Sintáctica: de las Estructuras a la Rección. Textos de Apoyo. Lingüística I. Editorial Síntesis. Madrid, España.

- Hirschbühler, Paul and Maria Luisa Rivero. 1983. Remarks on Free Relatives and Matching Phenomena. Linguistic Inquiry 14.505-519 http://aix 1.uottawa.ca/ romlab/pubs/RiveroHirschbuler.1983.pdf

- Leonetti, M. "El artículo", en I. Bosque y V. Demonte (eds.): Nueva Gramática Descriptiva de la Lengua Española, Madrid, Espasa-Calpe.

- _ _ (1999) Los determinantes, Madrid: Arco Libros.

- Rivero, María. (1982) “Las relativas restrictivas con que”. Nueva Revista de Filología Hispánica, T. 31, No. 2, pp. 195-234

- Schwarz, Florian. (2009). Two types of definites in natural language. Amherst, MA: University of Massachusetts. 
EL USO DE DETERMINANTES EN CONSTRUCCIONES CON ORACIONES SUBORDINADAS RELATIVAS
En la Ciudad de México, se presentaron a las 12:00 horas del día 11 del mes de julio del año 2019 en la Unidad Iztapalapa de la Universidad Autónoma Metropolitana, los suscritos miembros del jurado:

DR. JOSE LEMA LABADIE

DRA. LAURA JIMENEZ NORBERTO

DRA. ANTOINETTE HAWAYEK GONZALEZ

Bajo la Presidencia del primero y con carácter de Secretaria la última, se reunieron para proceder al Examen de Grado cuya denominación aparece al margen, para la obtención del grado de:

MAESTRO EN HUMANIDADES (LINGUISTICA)

DE: JORGE LUIS MORALES PEREZ

$y$ de acuerdo con el artículo 78 fracción III del Reglamento de Estudios Superiores de la Universidad Autónoma Metropolitana, los miembros del jurado resolvieron:

JORGE LUIS MORALES PEREZ ALUMNO

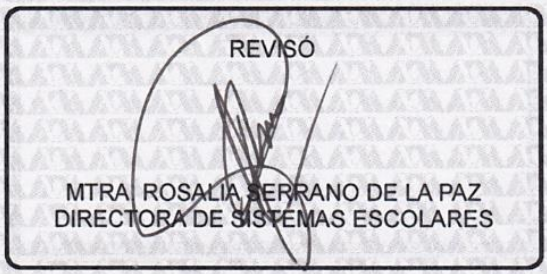

DE LA DIVISIÓN DE CSH

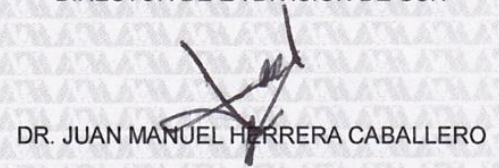

VOCAL<smiles>[CH]1CCCCC1</smiles>
Jumun

DRA. LAURA JIMENEZ NORBERTO

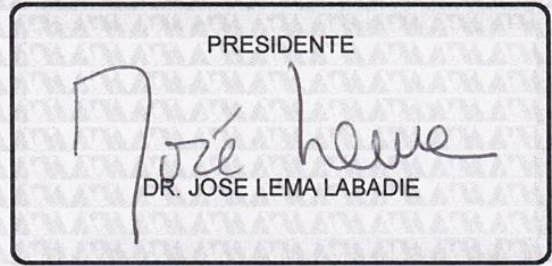

Acto continuo, el presidente del jurado comunicó al interesado el resultado de la evaluación $y$, en caso aprobatorio, le fue tomada la protesta. 